\title{
Results of Crack-Arrest Tests on Irradiated A 508 Class 3 Steel
}

Manuscript Completed: June 1995

Date Published: February 1998

Prepared by

S. K. Iskander, P. P. Milella, A. Pini

Oak Ridge National Laboratory

Managed by Lockheed Martin Energy Research Corporation

Oak Ridge National Laboratory

Oak Ridge, TN 37831-6151

M. G. Vassilaros, NRC Project Manager

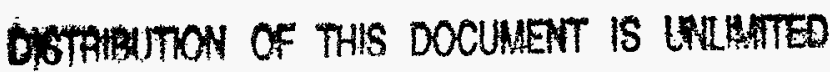

Prepared for

Division of Engineering Technology

Office of Nuclear Regulatory Research

U.S. Nuclear Regulatory Commission

Washington, DC 20555-0001

NRC Job Code L1098

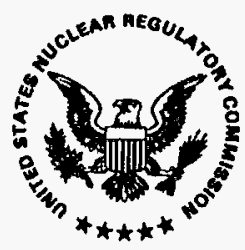




\section{DISCLAIMER}

This report was prepared as an account of work sponsored by an agency of the United States Government. Neither the United States Government nor any agency thereof, nor any of their employees, makes any warranty, express or implied, or assumes any legal liability or responsibility for the accuracy, completeness, or usefulness of any information, apparatus, product, or process disclosed, or represents that its use would not infringe privately owned rights. Reference herein to any specific commercial product, process, or service by trade name, trademark, manufacturer, or otherwise does not necessarily constitute or imply its endorsement, recommendation, or favoring by the United States Government or any agency thereof. The views and opinions of authors expressed herein do not necessarily state or reflect those of the United States Government or any agency thereof. 


\section{DISCLAIMER}

Portions of this document may be illegible electronic image products. Images are produced from the best available original document. 


\begin{abstract}
Ten crack-arrest toughness values for irradiated specimens of A 508 class 3 forging steel have been obtained. The tests were performed according to the American Society for Testing and Materials (ASTM) Standard Test Method for Determining Plane-Strain Crack-Arrest Fracture Toughness, $\mathrm{K}_{\mathrm{la}}$, of Ferritic Steels, E 1221-88. None of these values are strictly "valid" in all five ASTM E 1221-88 validity criteria. However, they are useful when compared to unirradiated crack-arrest specimen toughness values since they show the small (averaging approximately $10^{\circ} \mathrm{C}$ ) shifts in the mean and lower-bound crack-arrest toughness curves. This confirms that a low copper content in ASTM A 508 class 3 forging material can be expected to result in small shifts of the transition toughness curve. The shifts due to neutron irradiation of the lower bound and mean toughness curves are approximately the same as the Charpy V-notch (CVN) 41-J temperature shift. The nine crack-arrest specimens were irradiated at temperatures varying from 243 to $280^{\circ} \mathrm{C}$, and to a fluence varying from 1.7 to $2.7 \times 10^{19}$ neutrons $/ \mathrm{cm}^{2}$ $(>1 \mathrm{MeV}$. The test results were "normalized" to reference values that correspond to those of CVN specimens irradiated at $284^{\circ} \mathrm{C}$ to a fluence of $3.2 \times 10^{19}$ neutrons $/ \mathrm{cm}^{2}(>1 \mathrm{MeV})$ in the same capsule as . the crack-arrest specimens. This adjustment resulted in a shift to lower temperatures of all the data, and in particular moved two data points that appeared to lie close to or lower than the American Society of Mechanical Engineers $K_{l a}$ curve to positions that seemed more reasonable with respect to the remaining data. A special fixture was designed, fabricated, and successfully used in the testing. For reasons explained in the text, special blocks to receive the Oak Ridge National Laboratory clip gage were designed, and greater-than-standard crack-mouth opening displacements measured were accounted for.
\end{abstract}


$\ldots$ 


\section{Contents}

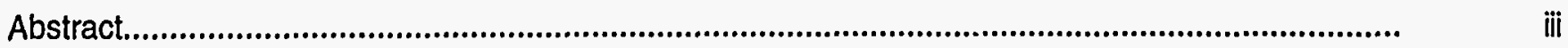

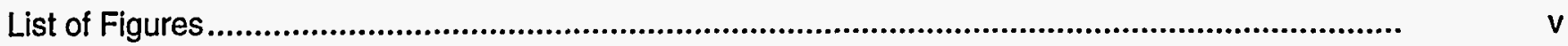

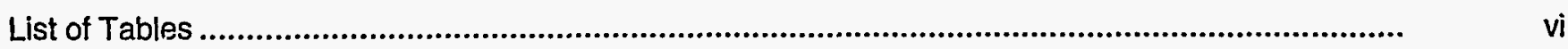

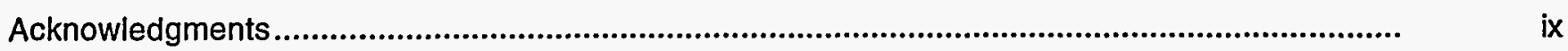

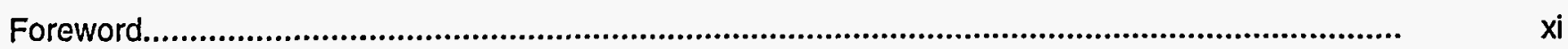

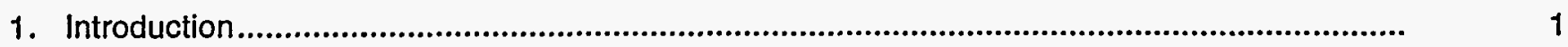

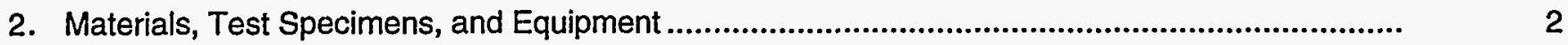

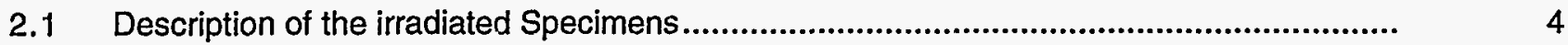

2.2 Adjustment of the Measured Crack-Mouth Opening Displacement ................................... 5

2.3 Crack-Arrest Toughness Values of Unirradiated and Irradiated Specimens ......................... $\quad 15$

2.4. Adjustment to Account for Differences in Irradiation Temperature and Exposure ............... 22

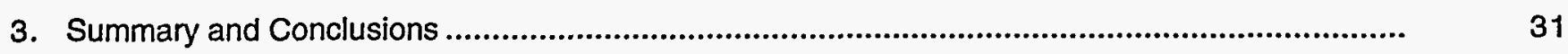

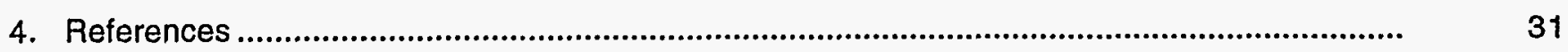

Appendix A: Results of temperature Survey..................................................................... A-1

Appendix B: Design Details of Clip-Gage Blocks................................................................. B-1

Appendix C: Pretest and Post-test Calculations According to ASTM E 1221-88 ........................... C-1

Appendix D: X-Y Plotter Output and Fracture Surfaces................................................................. D-1

\section{Figures}

1 Schematic of the irradiated crack-arrest specimens tested for ANPA. The dimensions

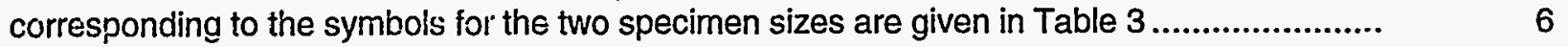

2 Irradiated crack-arrest specimen BK7 showing crack-tip region, circular imprint of the "spot-welder" electrodes, and the propagated crack at the bottom of the side grooves áfter test completion.

3 Perspective view of the clip gage attached to mounting blocks.

4 Locations of $M, 0$, and 1 at which one-half the crack-line displacements $V_{m}, V_{c}$, and $V_{1}$, respectively, were calculated

5 Crack-line wedge-loaded specimen compliance and regression fit of Equation (2.5)

Source: J. C. Newman, Jr., NASA Langley Research Center, Hampton, Virginia, Crack-Opening Displacements in Center-Crack, Compact, and Crack-Line, Wedge-Loaded Specimens, NASA TIN D-8268, July 1976. 
6 Energy versus lateral expansion of Charpy V-notch specimens in the T-L orientation for A 508 class 3 steel. This figure was used to estimate the lateral expansion at an energy level of $120 \mathrm{~J}$ and shows that a $0.89-\mathrm{mm}$ criterion is easily met.

7 Crack-arrest toughness values $\left(K_{a}\right)$ of unirradiated $A 508$ class 3 forging material with an $R T_{\mathrm{NDT}}=-12.5^{\circ} \mathrm{C}$, together with the lower bound at the ASME $\mathrm{K}_{\mathrm{b}}$ curves. A distinction is made between Kia values that satisfy all five ASTM E 122-88 validity criteria that ensure plane-strain conditions are met, and $\mathrm{K}_{\mathrm{a}}$ values that do not meet all five criteria.

8 Crack-arrest toughness values $\left(K_{2}\right)$ vs test temperature of irradiated A 508 class 3 forging material with $R T_{N D T}=-1.5^{\circ} \mathrm{C}$. The points near or below the ASME $K_{i a}$ curve are due to the low irradiation temperature of these two specimens compared to the other specimens.

9 Effect of the test temperature adjustment on the distribution of the crack-arrest toughness with respect to the ASME $\mathrm{K}_{\mathrm{ia}}$ curve. The arrow is one example of a typical adjustment.

10 Crack-arrest toughness values $(\mathrm{Ka})$ of irradiated A 508 class 3 forging material with an $\mathrm{RT}_{\mathrm{NDT}}=-1.5^{\circ} \mathrm{C}$, plotted as a function of the adjusted test temperature, together with the lower-bound and the ASME $K_{i a}$ curves.

11 Toughness of unirradiated and irradiated crack-arrest specimens from the ANPA

A 508 class 3 forging material.

12 Unirradiated and irradiated crack-arrest toughness lower-bound, mean, and ASME $K_{\mathrm{la}}$ curves for the ANPA A 508 class 3 forging material.

13 Toughness of unirradiated and irradiated crack-arrest specimens from the ANPA A 508 class 3 forging material, plotted as a function of (T-RT $\left.T_{N D T}\right)$.

\section{Tables}

1 Tensile properties of the A 508 class 3 forging after irradiation in the Ford Nuclear Reactor at a nominal temperature of $288^{\circ} \mathrm{C}$ to a fluence of $3.2 \times 10^{19}$ neutrons $/ \mathrm{cm}^{2}(>1 \mathrm{MeV})$

3 Nominal dimensions of the two sizes of irradiated crack-arrest specimens from the Italian Agenzia Nazionale per la Protezione dell' Ambiente (symbols correspond to Figure 1)

4 Normalized crack-line displacements (or compliance) at specimen front face, $x=0.25 \mathrm{~W}$, and at $x=0.1576 \mathrm{~W}$ as a function of crack length (plane stress conditions and Poisson's ratio $=0.3$ were assumed)

5 Results of regression fitting Equation (7) to be the compliances at positions 0 and 1 various crack lengths

6 Details of calculations to adjust the measured initiation and arrest crack-mouth opening displacement (CMOD) values to account for the $X_{m} N>0.25 W$ location at which they were measured 
7 Crack-arrest toughness values for unirradiated A 508 class 3 forging material with an $\mathrm{RT}_{\text {NDT }}=-12.5^{\circ} \mathrm{C}$ (all unirradiated crack-arrest tests conducted by ANPA)

8 Validity criteria (from ASTM E 1221-88) used to ensure that $\mathrm{K}_{\mathrm{a}}$ is a linear elastic, plane-strain value (symbols and nomenclature of $E$ 1221-88 have been also adopted)

9 Results of testing irradiated crack-arrest specimens machined from A 508 class 3 forging material

10 Details of the adjustment of testing temperature to a reference temperature of $284^{\circ} \mathrm{C}$ and a fluence of $3.2 \times 10^{19}$ neutrons $/ \mathrm{cm}^{2}(>1 \mathrm{MeV}$ ) for the irradiated A 508 class 3 forging crack-arrest specimens

11 Results of testing irradiated crack-arrest specimens machined from A 508 class 3 forging material

12 Mean and lower-bound $\mathrm{T}_{0}$ and $\mathrm{RT}_{\text {NDT }}$ values derived from unirradiated and irradiated crack-arrest toughness results of ANPA A 508 class 3 forging material (shift of 41-J Charpy V-notch impact energy level was $11 \mathrm{C}$ ) 



\section{Acknowledgments}

The following individuals not only contributed to the various tasks mentioned but also made many useful and constructive suggestions. The authors acknowledge Eric T. Manneschmidt and John J. Henry, Jr., for modifications to and shakedown of the new fixture, temperature survey, and the testing in the hot cells; David L. Thomas and Ronald L. Swain for much assistance with equipment; Lloyd J. Turner, Robert K. Lawson, John R. Gilley, and A. Earl Parker for very significant contributions to the transportation and testing of the irradiated specimens (the three large irradiated specimens were particularly difficult to move into the hot cell, and the authors acknowledge the ingenuity displayed by them). The design of the new remote test fixture was a daunting task, since it is capable of handling ten different test configurations (five different specimen sizes in the normal and inverted positions), so thanks go to Kenneth W. Boling, who designed the original. Julia L. Bishop is gratefully acknowledged for her expert help to produce this manuscript, Kathy Spence for her thorough manuscript editing, and SAIC for final manuscript preparation.

The authors also gratefully acknowledge the help of Jim C. Newman, Jr., NASA Langley Research Center, with the adjustment of the crack-mouth opening displacement (CMOD). The authors wish to thank Randy K. Nanstad and John G. Merkle for their thorough and helpful reviews. John Merkle suggested the closed-form derivation of the adjustment to the CMOD. The authors also acknowledge Charles W. Marschall, Battelle Columbus Division (BCD), and Alan R. Rosenfield, formerly of BCD, who were consulted during the choice of test temperatures for the irradiated specimens, for their reviews and for the helpful comments, particularly with regard to the references to the development of state-of-the art crackarrest testing methodology.

The authors are also grateful for the financial support and encouragement from the U.S. Nuclear Regulatory Commission, especially Alfred Taboada and Michael G. Vassilaros, the former and current Heavy-Section Steel Irradiation Program Monitors. 


\section{Foreword}

The work reported here was performed at the Oak Ridge National Laboratory (ORNL) under the Heavy-Section Steel Irradiation (HSSI) Program, W. R. Conwin, Program Manager. The program is sponsored by the Office of Nuclear Regulatory Research of the U.S. Nuclear Regulatory Commission (NRC). The technical monitor for the NRC is M. G. Vassilaros.

This report is designated HSSI Report 16. Reports in this series are listed below:

1. F. M. Haggag, W. R. Corwin, and R. K. Nanstad, Martin Marietta Energy Systems, Inc., Oak Ridge Natl. Lab., Oak Ridge, Tenn., Irradiation Effects on Strength and Toughness of Three-Wire Series-Arc Stainless Steel Weld Overlay Cladding, USNRC Report NUREG/CR-5511 (ORNLTM-11439), February 1990.

2. L. F. Miller, C. A. Baldwin, F. W. Stallman, and F. B. K. Kam, Martin Marietta Energy Systems, Inc., Oak Ridge Natl. Lab., Oak Ridge, Tenn., Neutron Exposure Parameters for the Metallurgical Test Specimens in the Sixth Heavy-Section Steel Irradiation Series, USNRC Report NUREG/CR-5409 (ORNL/TM-11267), March 1990.

3. S. K. Iskander, W. R. Corwin, and R. K. Nanstad, Martin Marietta Energy Systems, Inc., Oak Ridge Natl. Lab., Oak Ridge, Tenn., Results of Crack-Arrest Tests on Two Irradiated High-Copper Welds, USNRC Report NUREG/CR-5584 (ORNL/TM-11575), December 1990.

4. R. K. Nanstad and R. G. Berggren, Martin Marietta Energy Systems, Inc., Oak Ridge Natl. Lab., Oak Ridge, Tenn., Irradiation Effects on Charpy Impact and Tensile Properties of Low Upper-Shelf Welds, HSSI Series 2 and 3, USNRC Report NUREG/CR-5696 (ORNL/TM-11804), August 1991.

5. R. E. Stoller, Martin Marietta Energy Systems, Inc., Oak Ridge Natl. Lab., Oak Ridge, Tenn., Modeling the Influence of Irradiation Temperature and Displacement Rate on Radiation-Induced Hardening in Ferritic Steels, USNRC Report NUREG/CR5859 (ORNL/TM-12073), August 1992.

6. R. K. Nanstad, D. E. McCabe, and R. L. Swain, Martin Marietta Energy Systems, Inc., Oak Ridge Natl. Lab., Oak Ridge, Tenn., Chemical Composition $R T_{\text {NDT }}$ Determinations for Midland Weld WF-70, USNRC Report NUREG/CR-5914 (ORNL-6740), December 1992.

7. R. K. Nanstad, F. M. Haggag, D. E. McCabe, S. K. Iskander, K. O. Bowman, and B. H. Menke, Martin Marietta Energy Systems, Inc., Oak Ridge Natl. Lab., Oak Ridge, Tenn., Irradiation Effects on Fracture Toughness of Two High-Copper Submerged-Arc Welds, USNRC Report NUREG/CR-5913 (ORNL/TM-12156N1), October 1992.

8. S. K. Iskander, W. R. Corwin, and R. K. Nanstad, Martin Marietta Energy Systems, Inc., Oak Ridge Natl. Lab., Oak Ridge, Tenn., Crack-Arrest Tests on Two Irradiated High-Copper Welds, USNRC Report NUREG/CR-6139 (ORNL/TM-12513), March 1994.

9. R. E. Stoller, Martin Marietta Energy Systems, Inc., Oak Ridge Natl. Lab., Oak Ridge, Tenn., A Comparison of the Relative Importance of Copper Precipitates and Point Defects in Reactor Pressure Vessel Embrittlement, USNRC Report NUREG/CR-6231 (ORNL/TM-6811), December 1994.

10. D. E. McCabe, R. K. Nanstad, S. K. Iskander, and R. L. Swain, Martin Marietta Energy Systems, Inc., Oak Ridge Natl. Lab., Oak Ridge, Tenn., Unirradiated Material Properties of Midland Weld WF-70, USNRC Report NUREG/CR-6249 (ORNL/TM-12777), October 1994. 
11. P. M. Rice and R. E. Stoller, Lockheed Martin Energy Systems, Oak Ridge Natl. Lab., Oak Ridge, Tenn., Microstructural Characterization of Selected AEAUCSB Model FeCuMn Alloys, USNRC Report NUREG/CR-6332 (ORNLTM-12980), June 1996.

12. J. H. Giovanola and J. E. Crocker, SRI International, Fracture Toughness Testing with Cracked Round Bars: Feasibility Study, USNRC Report NUREG/CR-6342 (ORNL/SUB/94-DHK60), to be published.

13. F. M. Haggag and R. K. Nanstad, Lockheed Martin Energy Systems, Oak Ridge Natl. Lab., Oak Ridge, Tenn., Effects of Thermal Aging and Neutron Irradiation on the Mechanical Properties of Three-Wire Stainless Steel Weld Overlay Cladding, USNRC Report NUREG/CR-6363 (ORNL/TM-13047), to be published.

14. M. A. Sokolov and D. J. Alexander, Lockheed Martin Energy Systems, Oak Ridge Natl. Lab., Oak Ridge, Tenn., An Improved Correlation Procedure for Subsize and Full-Size Charpy Impact Specimen Data, USNRC Report NUREG/CR-6379 (ORNLTM-13088), to be published.

15. S. K. Iskander and R. E. Stoller, Lockheed Martin Energy Research Corporation, Oak Ridge Natl. Lab., Oak Ridge, Tenn., Results of Charpy V-Notch Impact Testing of Structural Steel Specimens Irradiated at $\sim 30^{\circ} \mathrm{C}$ to $1 \times 10^{6}$ neutrons $/ \mathrm{cm}^{2}$ in a Commercial Reactor Cavity, USNRC Report NUREG/CR-6399 (ORNL-6886), to be published.

16. This report.

The HSSI Program includes both follow-on and the direct continuation of work that was performed under the Heavy-Section Steel Technology (HSST) Program. Previous HSST reports related to irradiation effects in pressure vessel materials and those containing unirradiated properties of materials used in HSSI and HSST irradiation programs are tabulated below as a convenience to the reader.

C. E. Childress, Union Carbide Corp. Nuclear Div., Oak Ridge Natl. Lab., Oak Ridge, Tenn., Fabrication History of the First Two 12-in.-Thick A-533 Grade B, Class 1 Steel Plates of the Heavy-Section Steel Technology Program, ORNL-4313, February 1969.

T. R. Mager and F. O. Thomas, Westinghouse Electric Corporation, PWR Systems Division, Pittsburgh, Pa., Evaluation by Linear Elastic Fracture Mechanics of Radiation Damage to Pressure Vessel Steels, WCAP-7328 (Rev.), October 1969.

P. N. Randall, TRW Systems Group, Redondo Beach, Calif., Gross Strain Measure of Fracture Toughness of Steels, HSSTP-TR-3, Nov. 1, 1969.

L. W. Loechel, Martin Marietta Corporation, Denver, Colo., The Effect of Testing Variables on the Transition Temperature in Steel, MCR-69-189, Nov. 20, 1969.

W. O. Shabbits, W. H. Pryle, and E. T. Wessel, Westinghouse Electric Corporation, PWR Systems Division, Pittsburgh, Pa., Heavy-Section Fracture Toughness Properties of A533 Grade B Class 1 Steel Plate and Submerged Arc Weldment, WCAP-7414, December 1969.

C. E. Childress, Union Carbide Corp. Nuclear Div., Oak Ridge Natl. Lab., Oak Ridge, Tenn., Fabrication History of the Third and Fourth ASTM A-533 Steel Plates of the Heavy-Section Steel Technology Program, ORNL-4313-2, February 1970.

P. B. Crosley and E. J. Ripling, Materials Research Laboratory, Inc., Glenwood, III., Crack Arrest Fracture Toughness of A533 Grade B Class 1 Pressure Vessel Steel, HSSTP-TR-8, March 1970.

F. J. Loss, Naval Research Laboratory, Washington, D.C., Dynamic Tear Test Investigations of the Fracture Toughness of Thick-Section Steel, NRL-7056, May 14, 1970. 
T. R. Mager, Westinghouse Electric Corporation, PWR Systems Division, Pittsburgh, Pa., Post-Irradiation Testing of 2T Compact Tension Specimens, WCAP-7561, August 1970.

F. J. Witt and R. G. Berggren, Union Carbide Corp. Nuclear Div., Oak Ridge Natl. Lab., Oak Ridge, Tenn., Size Effects and Energy Disposition in Impact Specimen Testing of ASTM A533 Grade B Steel, ORNL/TM-3030, August 1970.

D. A. Canonico, Union Carbide Corp. Nuclear Div., Oak Ridge Natl. Lab., Oak Ridge, Tenn., Transition Temperature Considerations for Thick-Wall Nuclear Pressure Vessels, ORNL/TM-3114, October 1970.

T. R. Mager, Westinghouse Electric Corporation, PWR Systems Division, Pittsburgh, Pa., Fracture Toughness Characterization Study of A533, Grade B, Class 1 Steel, WCAP-7578, October 1970.

W. O. Shabbits, Westinghouse Electric Corporation, PWR Systems Division, Pittsburgh, Pa., Dynamic Fracture Toughness Properties of Heavy-Section A533 Grade B Class 1 Steel Plate, WCAP-7623, December 1970.

C. E. Childress, Union Carbide Corp. Nuclear Div., Oak Ridge Natl. Lab., Oak Ridge, Tenn., Fabrication Procedures and Acceptance Data for ASTM A-533 Welds and a 10-in.-Thick ASTM A-543 Plate of the Heavy Section Steel Technology Program, ORNL-TM-4313-3, January 1971.

D. A. Canonico and R. G. Berggren, Union Carbide Corp. Nuclear Div., Oak Ridge Natl. Lab., Oak Ridge, Tenn., Tensile and Impact Properties of Thick-Section Plate and Weldments, ORNL/TM-3211, January 1971.

C. W. Hunter and J. A. Williams, Hanford Eng. Dev. Lab., Richland, Wash., Fracture and Tensile Behavior of Neutron-Irradiated A533-B Pressure Vessel Steel, HEDL-TME-71-76, Feb. 6, 1971.

C. E. Childress, Union Carbide Corp. Nuclear Div., Oak Ridge Natl. Lab., Oak Ridge, Tenn., Manual for ASTM A533 Grade B Class 1 Steel (HSST Plate 03) Provided to the International Atomic Energy Agency, ORNL/TM-3193, March 1971.

P. N. Randall, TRW Systems Group, Redondo Beach, Calif., Gross Strain Crack Tolerance of A533-B Steel, HSSTP-TR-14, May 1, 1971.

C. L. Segaser, Union Carbide Corp. Nuclear Div., Oak Ridge Natl. Lab., Oak Ridge, Tenn., Feasibility Study, Irradiation of Heavy-Section Steel Specimens in the South Test Facility of the Oak Ridge Research Reactor, ORNL/TM-3234, May 1971.

H. T. Corten and R. H. Sailors, University of Illinois, Urbana, II., Relationship Between Material Fracture Toughness Using Fracture Mechanics and Transition Temperature Tests, T\&AM Report 346, Aug. 1, 1971.

L. A. James and J. A. Williams, Hanford Eng. Dev. Lab., Richland, Wash., Heavy Section Steel Technology Program Technical Report No. 21, The Effect of Temperature and Neutron Irradiation Upon the Fatigue-Crack Propagation Behavior of ASTM A533 Grade B, Class 1 Steel, HEDL-TME 72-132, September 1972.

P. B. Crosley and E. J. Ripling, Materials Research Laboratory, Inc., Glenwood, IIl., Crack Arrest in an Increasing K-Field, HSSTP-TR-27, January 1973.

W. J. Stelzman and R. G. Berggren, Union Carbide Corp. Nuclear Div., Oak Ridge Natl. Lab., Oak Ridge, Tenn., Radiation Strengthening and Embrittlement in Heavy-Section Steel Plates and Welds, ORNL-4871, June 1973.

J. M. Steichen and J. A. Williams, Hanford Eng. Dev. Lab., Richland, Wash., High Strain Rate Tensile Properties of Irradiated ASTM A533 Grade B Class 1 Pressure Vessel Steel, HEDL-TME 73-74, July 1973.

J. A. Williams, Hanford Eng. Dev. Lab., Richland, Wash., The Irradiation and Temperature Dependence of Tensile and Fracture Properties of ASTM A533, Grade B, Class 1 Steel Plate and Weldment, HEDL-TME 73-75, August 1973. 
J. A. Williams, Hanford Eng. Dev. Lab., Richland, Wash., Some Comments Related to the Effect of Rate on the Fracture Toughness of Irradiated ASTM A553-B Steel Based on Yield Strength Behavior, HEDL-SA 797, December 1974.

J. A. Williams, Hanford Eng. Dev. Lab., Richland, Wash., The Irradiated Fracture Toughness of ASTM A533, Grade B, Class 1 Steel Measured with a Four-Inch-Thick Compact Tension Specimen, HEDL-TME 75-10, January 1975.

J. G. Merkle, G. D. Whitman, and R. H. Bryan, Union Carbide Corp. Nuclear Div., Oak Ridge Natl. Lab., Oak Ridge, Tenn., An Evaluation of the HSST Program Intermediate Pressure Vessel Tests in Terms of Light-WaterReactor Pressure Vessel Safety, ORNL/TM-5090, November 1975.

J. A. Davidson, L. J. Ceschini, R. P. Shogan, and G. V. Rao, Westinghouse Electric Corporation, Pittsburgh, Pa., The Irradiated Dynamic Fracture Toughness of ASTM A533, Grade B, Class 1 Steel Plate and Submerged Arc Weldment, WCAP-8775, October 1976.

J. A. Williams, Hanford Eng. Dev. Lab., Richland, Wash., Tensile Properties of Irradiated and Unirradiated Welds of A533 Steel Plate and A508 Forgings, NUREG/CR-1158 (ORNL/SUB-79/50917/2), July 1979.

J. A. Williams, Hanford Eng. Dev. Lab., Richland, Wash., The Ductile Fracture Toughness of Heavy-Section Steel Plate, NUREG/CR-0859, September 1979.

K. W. Carlson and J. A. Williams, Hanford Eng. Dev. Lab., Richland, Wash., The Effect of Crack Length and Side Grooves on the Ductile Fracture Toughness Properties of ASTM A533 Steel, NUREG/CR-1171 (ORNL/SUB-79/50917/3), October 1979.

G. A. Clarke, Westinghouse Electric Corp., Pittsburgh, Pa., An Evaluation of the Unloading Compliance Procedure for J-Integral Testing in the Hot Cell, Final Report, NUREG/CR-1070 (ORNL/SUB-7394/1), October 1979.

P. B. Crosley and E. J. Ripling, Materials Research Laboratory, Inc., Glenwood, III., Development of a Standard Test for Measuring $K_{l a}$ with a Modified Compact Specimen, NUREG/CR-2294 (ORNL/SUB-81/7755/1), August 1981.

H. A. Domian, Babcock and Wilcox Company, Alliance, Ohio, Vessel V-8 Repair and Preparation of Low UpperShelf Weldment, NUREG/CR-2676 (ORNL/SUB/81-85813/1), June 1982.

R. D. Cheverton, S. K. Iskander, and D. G. Ball, Union Carbide Corp. Nuclear Div., Oak Ridge Natl. Lab., Oak Ridge, Tenn., PWR Pressure Vessel Integrity During Overcooling Accidents: A Parametric Analysis, NUREG/CR-2895 (ORNL/TM-7931), February 1983.

J. G. Merkle, Union Carbide Corp. Nuclear Div., Oak Ridge Natl. Lab., Oak Ridge, Tenn., An Examination of the Size Effects and Data Scatter Observed in Small Specimen Cleavage Fracture Toughness Testing, NUREG/CR-3672 (ORNL/TM-9088), April 1984.

W. R. Corwin, Martin Marietta Energy Systems, Inc., Oak Ridge Natl. Lab., Oak Ridge, Tenn., Assessment of Radiation Effects Relating to Reactor Pressure Vessel Cladding, NUREG/CR-3671 (ORNL-6047), July 1984.

W. R. Corwin, R. G. Berggren, and R. K. Nanstad, Martin Marietta Energy Systems, Inc., Oak Ridge Natl. Lab., Oak Ridge, Tenn., Charpy Toughness and Tensile Properties of a Neutron Irradiated Stainless Steel SubmergedArc Weld Cladding Overlay, NUREG/CR-3927 (ORNLTM-9709), September 1984.

J. J. McGowan, Martin Marietta Energy Systems, Inc., Oak Ridge Natl. Lab., Oak Ridge, Tenn., Tensile Properties of Irradiated Nuclear Grade Pressure Vessel Plate and Welds for the Fourth HSST Irradiation Series, NUREG/CR3978 (ORNL/TM-9516), January 1985. 
J. J. McGowan, Martin Marietta Energy Systems, Inc., Oak Ridge Natl. Lab., Oak Ridge, Tenn., Tensile Properties of Irradiated Nuclear Grade Pressure Vessel Welds for the Third HSST Irradiation Series, NUREG/CR-4086 (ORNL/TM-9477), March 1985.

W. R. Corwin, G. C. Robinson, R. K. Nanstad, J. G. Merkle, R. G. Berggren, G. M. Goodwin, R. L. Swain, and T. D. Owings, Martin Marietta Energy Systems, Inc., Oak Ridge Natl. Lab., Oak Ridge, Tenn., Effects of Stainless Steel Weld Overlay Cladding on the Structural Integrity of Flawed Steel Plates in Bending, Series 1, NUREG/CR-4015 (ORNL/TM-9390), April 1985.

W. J. Stelzman, R. G. Berggren, and T. N. Jones, Martin Marietta Energy Systems, Inc., Oak Ridge Natl. Lab., Oak Ridge, Tenn., ORNL Characterization of Heavy-Section Steel Technology Program Plates 01, 02, and 03, NUREG/CR-4092 (ORNL/TM-9491), April 1985.

G. D. Whitman, Martin Marietta Energy Systems, Inc., Oak Ridge Natl. Lab., Oak Ridge, Tenn., Historical Summary of the Heavy-Section Steel Technology Program and Some Related Activities in Light-Water Reactor Pressure Vessel Safety Research, NUREG/CR-4489 (ORNL-6259), March 1986.

R. H. Bryan, B. R. Bass, S. E. Bolt, J. W. Bryson, J. G. Merkle, R. K. Nanstad, and G. C. Robinson, Martin Marietta Energy Systems, Inc., Oak Ridge Natl. Lab., Oak Ridge, Tenn., Test of 6-in.-Thick Pressure Vessels. Series 3: Intermediate Test Vessel V-8A - Tearing Behavior of Low Upper-Shelf Material, NUREG-CR-4760 (ORNL-6187), May 1987.

D. B. Barker, R. Chona, W. L. Fourney, and G. R. Irwin, University of Maryland, College Park, Md., A Report on the Round Robin Program Conducted to Evaluate the Proposed ASTM Standard Test Method for Determining the Plane Strain Crack Arrest Fracture Toughness, $K_{l a}$, of Ferritic Materials, NUREG/CR-4966 (ORNL/SUB/79-7778/4), January 1988.

L. F. Miller, C. A. Baldwin, F. W. Stallman, and F. B. K. Kam, Martin Marietta Energy Systems, Inc., Oak Ridge Natl. Lab., Oak Ridge, Tenn., Neutron Exposure Parameters for the Metallurgical Test Specimens in the Fifth Heavy-Section Steel Technology Irradiation Series Capsules, NUREG/CR-5019 (ORNL/TM-10582), March 1988.

J. J. McGowan, R. K. Nanstad, and K. R. Thoms, Martin Marietta Energy Systems, Inc., Oak Ridge Natl. Lab., Oak Ridge, Tenn., Characterization of Irradiated Current-Practice Welds and A533 Grade B Class 1 Plate for Nuclear Pressure Vessel Service, NUREG/CR-4880 (ORNL-6484N1 and V2), July 1988.

R. D. Cheverton, W. E. Pennell, G. C. Robinson, and R. K. Nanstad, Martin Marietta Energy Systems, Inc., Oak Ridge Natl. Lab., Oak Ridge, Tenn., Impact of Radiation Embrittlement on Integrity of Pressure Vessel Supports for Two PWR Plants, NUREG/CR-5320 (ORNL/TM-10966), February 1989.

J. G. Merkle, Martin Marietta Energy Systems, Inc., Oak Ridge Natl. Lab., Oak Ridge, Tenn., An Overview of the Low-Upper-Shelf Toughness Safety Margin Issue, NUREG/CR-5552 (ORNL/TM-11314), August 1990.

R. D. Cheverton, T. L. Dickson, J. G. Merkle, and R. K. Nanstad, Martin Marietta Energy Systems, Inc., Oak Ridge Natl. Lab., Oak Ridge, Tenn., Review of Reactor Pressure Vessel Evaluation Report for Yankee Rowe Nuclear Power Station (YAEC No. 1735), NUREG/CR-5799 (ORNL/TM-11982), March 1992. 


\title{
Results of Crack-Arrest Tests on Irradiated A 508 Class 3 Steel $^{*}$
}

\author{
S. K. Iskander, P. P. Milella, ${ }^{\dagger}$ and A. Pini $^{\dagger}$
}

\section{Introduction}

The exposure of some reactor pressure vessel (RPV) ferritic steels to neutron irradiation fluences of the order of $2 \times 10^{19}$ neutrons $/ \mathrm{cm}^{2}(>1 \mathrm{MeV})$ can cause changes in the shape and an increase in the transition temperature of the Charpy V-notch (CVN) impact energy curve. ${ }^{1}$ The present procedure in Title 10, Code of Federal Regulations, Part 50 (10CFR50), ${ }^{2}$ to account for the possible degradation of these steels is to shift the American Society of Mechanical Engineers (ASME) fracture toughness curves to a higher temperature by the amount of shift exhibited by CVN impact energy curves subjected to the same fluence. This procedure assumes that: (1) the ASME fracture toughness curves of the same material would have shifted by the same amount as the CVN impact energy had they been exposed to the same irradiation fluence and irradiation temperature, and (2) the fracture toughness curves of the irradiated material are of the same shape as those of unirradiated material. Since correlations exist between CVN impact energy and toughness, ${ }^{3}$ and the CVN impact energy curves for these steels show changes in shape and an increase in the transition temperature, it might be expected that the fracture toughness curves for irradiation-sensitive RPV steels would also show changes in shape. A relatively small shape change of the crack-initiation toughness, $\mathrm{K}_{\mathrm{Jc}}$, versus temperature curve has been observed for Heavy-Section Steel Irradiation (HSSI) Program weld 73W (ref. 4).

For more than two decades, the U.S. Nuclear Regulatory Commission (NRC) has sponsored much research at the Oak Ridge National Laboratory (ORNL) and elsewhere to study the effects of neutron irradiation on the fracture toughness of RPV steels. The first data on irradiated crack-arrest specimens were obtained at Battelle under sponsorship of the NRC. ${ }^{5}$ Battelle and Westinghouse researchers performed a more extensive study under sponsorship of the Electric Power Research Institute. ${ }^{6.7}$ The NRC-supported HSSI Program has performed considerable research into the irradiated behavior of RPV steels, namely, the Fourth, ${ }^{8}$ Fifth, ${ }^{4}$ Sixth, ${ }^{9,10}$ and Seventh ${ }^{11}$ Irradiation Series. In particular, the HSSI Sixth Irradiation Series investigated the effects of irradiation on the temperature shift and shape change of the crack-arrest toughness, $K_{a}{ }^{\ddagger}$ versus temperature curve. The results of the Sixth Irradiation Series showed that the shift of the lower bound to the data was about the same as the shift in transition temperature, and no shape change was observed.

The number of published"* $\mathrm{K}_{\mathrm{a}}$ data points for irradiated RPV steels is about 73 , of which 39 were generated in the Sixth Irradiation Series. Due to this paucity of data, the NRC has arranged for ORNL to test the nine irradiated crack-arrest specimens belonging to the Italian Agenzia Nazionale per la Protezione dell'Ambiente (ANPA). ${ }^{\text {tt }}$ The material is of a type that is also used in U.S. RPVs, thus the results have usefulness and applicability to the integrity assessment of U.S. RPVs.

\footnotetext{
"Research sponsored by the Office of Nuclear Regulatory Research, Division of Engineering Technology, U.S. Nuclear Regulatory Commission, under Interagency Agreement DOE 1886-8109-8L with the U.S. Department of Energy under contract DE-AC05-96OR22464 with Lockheed Martin Energy Research Corporation.

${ }^{\dagger}$ Agenzia Nazionale per la Protezione dell'Ambiente (formerly ENEA/DISP), Technologies Division, Via V. Brancati 48, 00144 Roma, Italy.

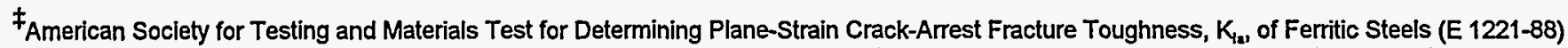
makes a distinction between the plane-strain crack-arrest toughness value, $K_{1 a}$, which meets all the validity criteria, and the observed value, $K_{a}$.

"The principal author has recently learned that the Staatliche Materialprufungsanstalt (MPA), Stuttgart, Germany, is preparing a report on the results of tests on more than a dozen irradiated crack-arrest toughness specimens.
}

${ }^{+}$Recent changes have moved the ltalian Nuclear Safety Authority, formerly known as ENEA-DISP, to the Agenzja Nazionale per la Protezione dell'Ambiente (ANPA). 
The general purpose of this report is to document in detail the material of the test specimens, the equipment used, and the results of the tests performed on the nine irradiated crack-arrest specimens. For the reason explained below, the observed values of crack-mouth opening displacement (CMOD) were adjusted. To account for the differences in irradiation temperature and fluence values between the nine crack-arrest specimens, the test temperatures of the crack-arrest specimens were "adjusted" to correspond to those of reference irradiation temperature and fluence values. The raw data, the details of the adjustments, the final results, and the comparison between the curve shift due to irradiation for the crack-arrest specimens and that of reference CVN specimens will then be presented. A future report is planned that will perform more data analyses and compare the results to other data.

\section{Materials, Test Specimens, and Equipment}

The specimens were machined from a forging material produced in Italy that conforms to the American Society for Testing and Materials (ASTM) Specification for Quenched and Tempered Vacuum-Treated Carbon and Alloy Steel Forgings for Pressure Vessels, Class 3 (A 508 Class 3), A 508-81. All toughness specimens were machined in the C-R orientation:" Some time ago, ANPA started an extensive research program to characterize this forging. ${ }^{12}$ The research program encompassed mechanical property data from the following types of unirradiated and irradiated specimens: tensile, Charpy impact (both standard and precracked), compact tensile, and crack arrest. Several institutions were involved in the irradiation and testing of these specimens: ENEA CRE Casaccia Laboratories, Battelle, and two laboratories of the French Commissariat a l'Energie Atomique. Previously reported crack initiation data for this steel indicated that the irradiation-induced shift of $\mathrm{K}_{\mathrm{Jc}}$ was less than the CVN curve shift for fluences of 1 and $5.5 \times 10^{19}$ neutrons $/ \mathrm{cm}^{2}(>1 \mathrm{MeV}) .{ }^{13}$ ANPA tested the unirradiated crack-arrest specimens and originally planned to have the irradiated crack-arrest specimens tested at Battelle, but the hot cell facilities at Battelle were decommissioned before the testing could be performed. In this report, for brevity, the unirradiated and nine irradiated crack-arrest specimens are sometimes referred to as the "ANPA specimens."

Details of the tensile and Charpy results are in a report by Marschall et al. ${ }^{\dagger}$ from which the following data were excerpted. The room-temperature tensile yield and ultimate strengths for unirradiated specimens were 463 and $605 \mathrm{MPa}$, respectively, and increased $\propto 9$ and $4 \%$, respectively, when irradiated at a nominal temperature and fluence of $288^{\circ} \mathrm{C}$ and $3 \times 10^{19}$ neutrons $/ \mathrm{cm}^{2}(>1 \mathrm{MeV}$, respectively. The $41-\mathrm{J}$ Charpy transition temperature and upper shelf for the unirradiated specimens were $-58^{\circ} \mathrm{C}$ and $260 \mathrm{~J}$, respectively, and changed by +11 and $-6 \%$, respectively, for the same irradiation conditions just mentioned. In particular, the 41-J Charpy transition temperature shift for this material and the same irradiation conditions was $11 \mathrm{C}$. $^{\ddagger}$ These small changes are due to the relatively small copper and moderate nickel contents ( 0.06 and $0.74 \%$, respectively).

The irradiated tensile yield strength and Young's modulus, $E$, as a function of temperature are needed to evaluate the experimental data. The values of the $0.2 \%$ offset yield strength at several temperatures are given in Table 1 and were also excerpted from the report by Marschall et al. ${ }^{+}$Only the values at 25 and $150^{\circ} \mathrm{C}$ were used, and the

\footnotetext{
"Nomenclature for fracture toughness specimen orientation is described in ASTM Standard Test Method for Plane-Strain Fracture Toughness of Metallic Materials, E 399-90; for hollow cylinders, the first letter is the direction of the load relative to the crack plane, and the second corresponds to the direction of propagation of the flaw. Thus, for a C-R orientation, the normal to the crack plane is in the circumferential direction and propagates radially.

${ }^{\dagger}$ C. W. Marschall, W. J. Zielenbach, R. W. Tayloe, Jr., and A. R. Rosenfield, Effects of Fast Neutron Irradiation on the Mechanical Properties of an SA508 Class 3 Ring Forging, Battelle, Columbus, Ohio, 1995.

${ }_{A}$ distinction is made in this report between temperatures, which are designated with a degree symbol, and temperature intervals in the same units, without the degree symbol.
} 
Table 1. Tensile properties of the $A 508$ class 3 forging after irradiation in the Ford Nuclear Reactor at a nominal temperature of $288^{\circ} \mathrm{C}$ to a fluence of $3.2 \times 10^{19}$ neutrons $/ \mathrm{cm}^{2}(>1 \mathrm{MeV})$

\begin{tabular}{||c|c|c|c|c||}
\hline \multirow{2}{*}{ Specimen } & \multicolumn{2}{|c|}{$\begin{array}{c}\text { Test } \\
\text { temperature }\end{array}$} & \multicolumn{2}{c|}{$\begin{array}{c}\text { 0.2\% Offset yield } \\
\text { strength }\end{array}$} \\
\cline { 2 - 5 } & $\left.{ }^{\circ} \mathrm{C}\right)$ & $\left({ }^{\circ} \mathrm{F}\right)$ & $(\mathrm{MPa})$ & $(\mathrm{ksi})$ \\
\hline BT5 & 25 & 77 & 499 & 72.4 \\
BT3 & 150 & 302 & 450 & 65.3 \\
BT4 & 200 & 392 & 439 & 63.7 \\
BT1 & 250 & 482 & 445 & 64.5 \\
BT2 & 290 & 554 & 445 & 64.5 \\
\hline Source: C. W. Marschall, W. J. Zielenbach, R. E. Tayloe, Jr., and A. R. Rosenfield, Battelle, Columbus, \\
Ohio, Effects of Fast-Neutron irradiation on the Mechanical Properties of an SA-508 Class 3 Ring \\
Forging, 1995.
\end{tabular}

yield strength, $\sigma_{0.2 \text { yleld }}$, at any intermediate temperature, $t$, was calculated using a straight line between these two points by the following expression:

$$
\sigma_{0.2 \text { yield }}=508.8-0.392 \mathrm{t}, \quad 25 \leq \mathrm{t} \leq 150^{\circ} \mathrm{C},
$$

with $(t)$ in ${ }^{\circ} \mathrm{C}$ and $\sigma_{0.2 \text { yield }}$ in MPa. The corresponding expression for $t$ in ${ }^{\circ} \mathrm{F}$ and $\sigma_{0.2 \text { yletd }}$ in $\mathrm{ksi}$ is:

$$
\sigma_{0.2 \text { yield }}=74.83-0.03156 \mathrm{t}, \quad 77 \leq \mathrm{t} \leq 300^{\circ} \mathrm{F} .
$$

Young's modulus, $E_{\text {. in }} \mathrm{GPa}$ and $t$ in ${ }^{\circ} \mathrm{C}$ is

$$
E=207.2-0.0571 t, \quad-198 \leq t \leq 260^{\circ} \mathrm{C},
$$

and for $E$ in $\mathrm{ksi}$ and $\mathrm{t}$ in ${ }^{\circ} \mathrm{F}$ :

$$
E=30,200-4.6 \mathrm{t}, \quad-325 \leq t \leq 500^{\circ} \mathrm{F} .
$$

Equation (3) for $E$ in Sl units was obtained from Equation (4), the latter given in ref. 14. Young's modulus is needed in the calculation of $\mathrm{K}_{\mathrm{b}}$ and $\mathrm{K}_{\mathrm{a}}$.

The HSSI Program has previously tested irradiated crack-arrest specimens using a specialiy designed and manufactured fixture., ${ }^{9,10}$ However, this fixture was too small for the large ANPA specimens, and a larger remote crack-arrest fixture was designed, fabricated, and tested. This fixture, like its predecesscr, included a simple specimen hold-down feature that permitted easy wedge extraction during the unloading portion of the test sequence..$^{15}$ Prior to its use with irradiated specimens, the operation of the new remote crack-arrest fixture was verified, using unirradiated crack-arrest specimens from the Midland weld WF-70. ${ }^{16}$ Crack-arrest testing was 
performed according to ASTM Test for Determining Plane-Strain Crack-Arrest Fracture Toughness, $K_{12}$, of Ferritic Steels (E 1221-88). During the unirradiated specimen verification tests, thermocouples were tack-welded to the specimens to check the removable temperature indicator that was to be used in the hot cell. A survey of the temperature distribution in the crack-arrest specimens was performed over the temperature range within which the device was to be used and for the two testing positions allowed in ASTME 1221-88, the "normal" and "inverted" crack-arrest specimen positions. In the so-called normal testing position, the flanges of the split pins that receive the loading wedge sit over the specimen, while in the inverted configuration, the specimen sits over the flanges. The inverted configuration was invented by Irwin ${ }^{*}$ and is described in ref. 17. The inverted position minimizes friction and damping effects and is preferred for attaining crack-arrest toughness values at relatively higher temperatures. ${ }^{18}$ The normal position is used in testing at low temperatures to aid in the arrest of the flaw. In the temperature survey, the maximum difference in reading between the removable temperature indicator and any of the seven thermocouples tack-welded to the specimen was less than $2^{\circ} \mathrm{C}$. The data obtained from this survey are presented in Appendix $A$.

\subsection{Description of the Irradiated Specimens}

Nine crack-arrest specimens of two different sizes were manufactured by ANPA from the ASTM A 508 class 3 forging for the irradiation effects studies. The chemical compositions of the specimens are given in Table 2. Note the very low copper content of this forging, $0.06 \%$, which reflects state-of-the-art steelmaking practice and conforms to a specific requirement issued by ANPA for new reactors. The external dimensions of the three "large" specimens are $25 \times 200 \times 192 \mathrm{~mm}$, while the dimensions of the six "small" specimens are $12.5 \times 100 \times 96 \mathrm{~mm}$. The nine

Table 2. Chemical composition of the $\mathbf{A} 508$ class 3 forging used in this study

\begin{tabular}{||l|l|l|c||}
\hline \multirow{2}{*}{ Element } & \multicolumn{3}{|c|}{$\begin{array}{c}\text { Composition } \\
\text { (wt \%) }\end{array}$} \\
\cline { 2 - 4 } & $\begin{array}{c}\text { Melt } \\
\text { analysis }\end{array}$ & $\begin{array}{c}\text { Product } \\
\text { analysis }\end{array}$ & $\begin{array}{c}\text { ASTM A 508 } \\
\text { Class 3 } \\
\text { specifications }\end{array}$ \\
\hline Carbon & 0.21 & 0.18 & 0.25 max \\
Manganese & 1.41 & 1.33 & 1.20 to 1.50 \\
Phosphorus & 0.011 & 0.010 & $a$ \\
Sulfur & 0.006 & 0.004 & 0.025 max \\
Silicon & 0.28 & 0.27 & 0.15 to 0.40 \\
Nickel & 0.75 & 0.735 & 0.40 to 1.0 \\
Chromium & 0.10 & 0.10 & 0.25 max \\
Molybdenum & 0.52 & 0.495 & 0.45 to 0.60 \\
Copper & 0.06 & 0.06 & $a$ \\
\hline ASTM A 508-81 Supplementary Requirement S9.1.1: P 0.012 maximum heat and 0.015 maximum product; \\
\hline
\end{tabular}

ANPA crack-arrest specimens were encapsulated at Battelle and irradiated in the Ford Nuclear Reactor (FNR) at the University of Michigan (irradiation was supervised by Battelle). Details of the irradiation are presented in a report

A. R. Rosenfield, Rosenfield and Rosenfield, Columbus, Ohio, telephone conversation with S. K. Iskander, Oak Ridge National Laboratory, Oak Ridge, Tennessee, October 14, 1995. 
by Marschall et al. " The fluences for the nine specimens varied between approximately 1.8 to $2.7 \times 10^{19}$ nuetrons/ $\mathrm{cm}^{2}\left(>1 \mathrm{MeV}\right.$, and the irradiation temperatures varied from 240 to $280^{\circ} \mathrm{C}$. Following completion of the irradiation, the specimens were shipped from the FNR to ORNL for testing.

A schematic of the geometry of the ANPA specimens is shown in Figure 1, and the dimensions corresponding to the symbols in this figure are given in Table 3 . The crack-starter notch was embrittled using a special technique introduced by Milella and pioneered by ENEA. ${ }^{19}$ In this special technique, a large current, in the 2- to 3-kA range, is discharged into the crack-arrest specimen notch area to heat, self-quench, and embrittle the material in the vicinity of the crack-tip region. The process is similar to that used for spot welding, but in this case, the crack-arrest specimen is placed between the two spot-welding electrodes. Figure 2 is a photograph, taken through the Kollmorgen periscope, of an irradiated specimen crack-tip region after a test and shows the circular imprint of the "spot-welder electrode," as well as the propagated crack at the bottom of the side grooves.

\subsection{Adjustment of the Measured Crack-Mouth Opening Displacement}

In the design of the ANPA crack-arrest specimens, the measurement of the CMOD had originally been intended to be performed by a clip gage seated on knife edges located on the front face of the specimen. At ORNL, the CMOD of crack-arrest specimens is measured using clip-gage blocks with conical recesses that receive the conical points of the clip gage. In the case of unirradiated specimens, the clip-gage blocks are attached by driving split pins into slightly undersize holes. If the specimens are to be irradiated, the clip-gage blocks are attached in the same manner as unirradiated specimens, and to minimize the possibility of the clip-gage blocks becoming detached, they are tack-welded to the specimens.

Since ORNL has considerable experience with the clip gages having conical points, after discussions between all interested parties, it was decided to use the ORNL method. Clip-gage blocks were designed, manufactured, and attached remotely to the ANPA specimens. Detailed drawings of the clip-gage blocks are shown in Appendix B, and a perspective view of the clip gage attached to a mounting block is shown in Figure 3 . The CMOD measurements were made at distances of 0.29 and $0.27 \mathrm{~W}$ from the load line (LL) for the small and large specimens, respectively, rather than the $0.25 \mathrm{~W}$ location prescribed in the crack-arrest standard. According to ASTM E 1221-88, the CMOD should be measured at a distance of $X_{0}=0.25 \mathrm{~W}$, and on the opposite side of the crack tip from the $L L$, where $W$ is the nominal width of the specimen, as shown in Figure 4 . Hence, the measured CMOD values were greater than those that would have been measured at the recommended distance. To calculate the stress-intensity factors for crack-initiation and crack-arrest, $K_{0}$ and $K_{2}$, respectively, using the expressions given in ASTME 1221-88, the measured displacements were adjusted to values that would have been measured at a distance of $0.25 \mathrm{~W}$ from the $\mathrm{LL}$, using the method described below.

The method to determine the required adjustment uses the experimentally measured CMODs at a distance $>0.25 \mathrm{~W}$ and those determined analytically by Newman ${ }^{20}$ to interpolate for the required CMOD at $0.25 \mathrm{~W}$. Newman calculated the crack-line displacements for a crack-ine wedge-loaded specimen, the geometry of which corresponds to the ASTM specimen, i.e., one for which $2 \mathrm{H} N \mathrm{~N}=1.2$, where $2 \mathrm{H}$ is the total specimen height and $W$ is the nominal width. Plane stress conditions and a Poisson's ratio of 0.3 were assumed. The crack-line displacements were calculated by Newman at several locations from the LL. Two of these distances are 0.25 and $0.1576 \mathrm{~W}$, where $\mathrm{W}$ is the nominal specimen width that corresponds to the distance from the LL to the back face of the specimen. The $0.25 \mathrm{~W}$ location is the front-face location corresponding to that prescribed in ASTM E 1221-88 Referring to Figure 4 , the conical recesses of the clip-gage blocks are located at the distance, $X_{M}$, from the LL.

\footnotetext{
"C. W. Marschall, W. J. Zielenback, R. W. Tayloe, Jr., and A. R. Rosenfield, Effects of Fast Neutron Irraciation on the Mechanical Properties of an SA 508 Class 3 Ring Forging, Battele, Columbus, Ohio. 1995.

The irradiation temperature and neutron exposure for each specimen will be given together with the measured crack-arrest toughness values in a later section.
} 


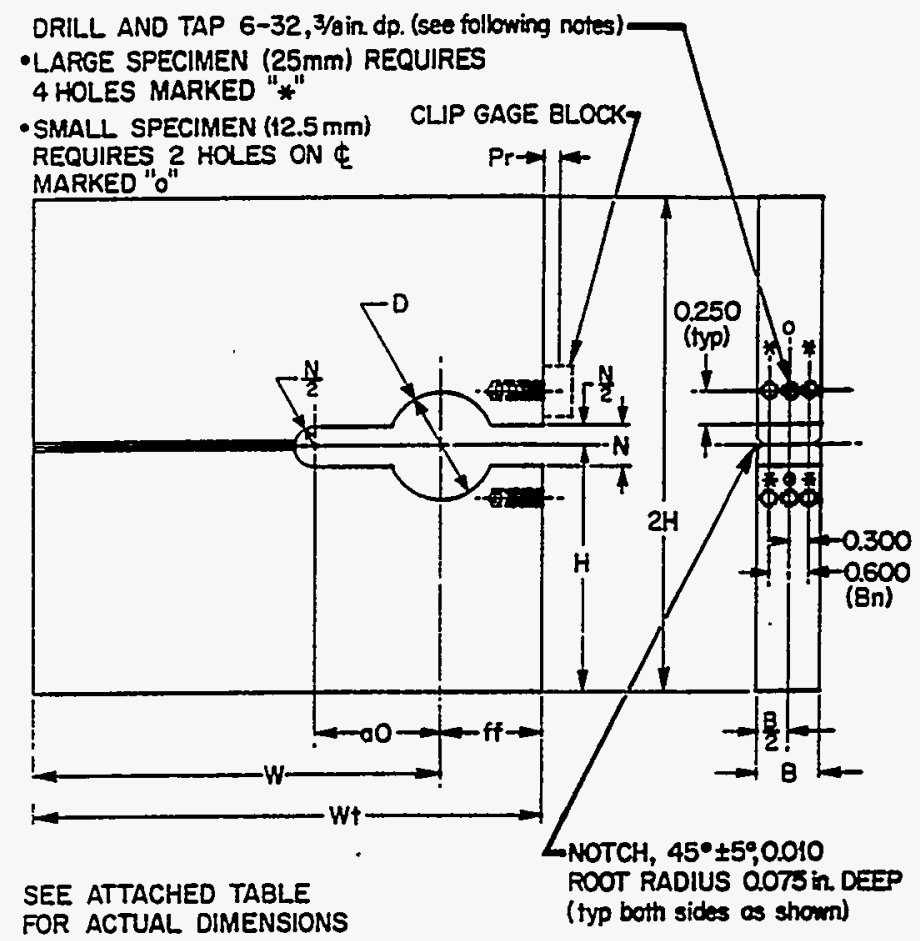

Figure 1. Schematic of the irradiated crack-arrest specimens tested for ANPA. The dimensions corresponding to the symbols for the two specimen sizes are given in Table 3.

Table 3. Nominal dimensions of the two sizes of irradiated crack-arrest specimens from the Italian Agenzia Nazionale per la Protezione dell'Ambiente (symbols correspond to Figure 1)

\begin{tabular}{||l|r|c|c|c||}
\hline \multirow{2}{*}{ Dimensions } & \multicolumn{2}{|c|}{ Small specimen } & \multicolumn{2}{c||}{ Large specimen } \\
\cline { 2 - 5 } & $(\mathrm{mm})$ & (in.) & (mm) & (in.) \\
\hline Nominal width, W & 80.0 & 3.150 & 160.0 & 6.299 \\
Total width, Wt & 100.0 & 3.937 & 200.0 & 7.874 \\
Total height, 2H & 96.0 & 3.780 & 192.0 & 7.559 \\
Specimen thickness, B & 12.5 & 0.492 & 25.0 & 0.984 \\
Thickness between side grooves, & 9.4 & 0.370 & 19.4 & 0.764 \\
minimum, Bn & & & & \\
Thickness between side grooves, & 9.8 & 0.386 & 19.7 & 0.776 \\
average, Bn & & & & \\
Thickness between side grooves, & 9.6 & 0.378 & 19.6 & 0.770 \\
average, Bn & & & & \\
Initial crack depth, a0 & 28.0 & 1.102 & 56.0 & 2.205 \\
Loading hole diameter, D & 21.2 & 0.834 & 42.4 & 1.671 \\
Notch width, N & 8.0 & 0.315 & 16.0 & 0.630 \\
\hline
\end{tabular}




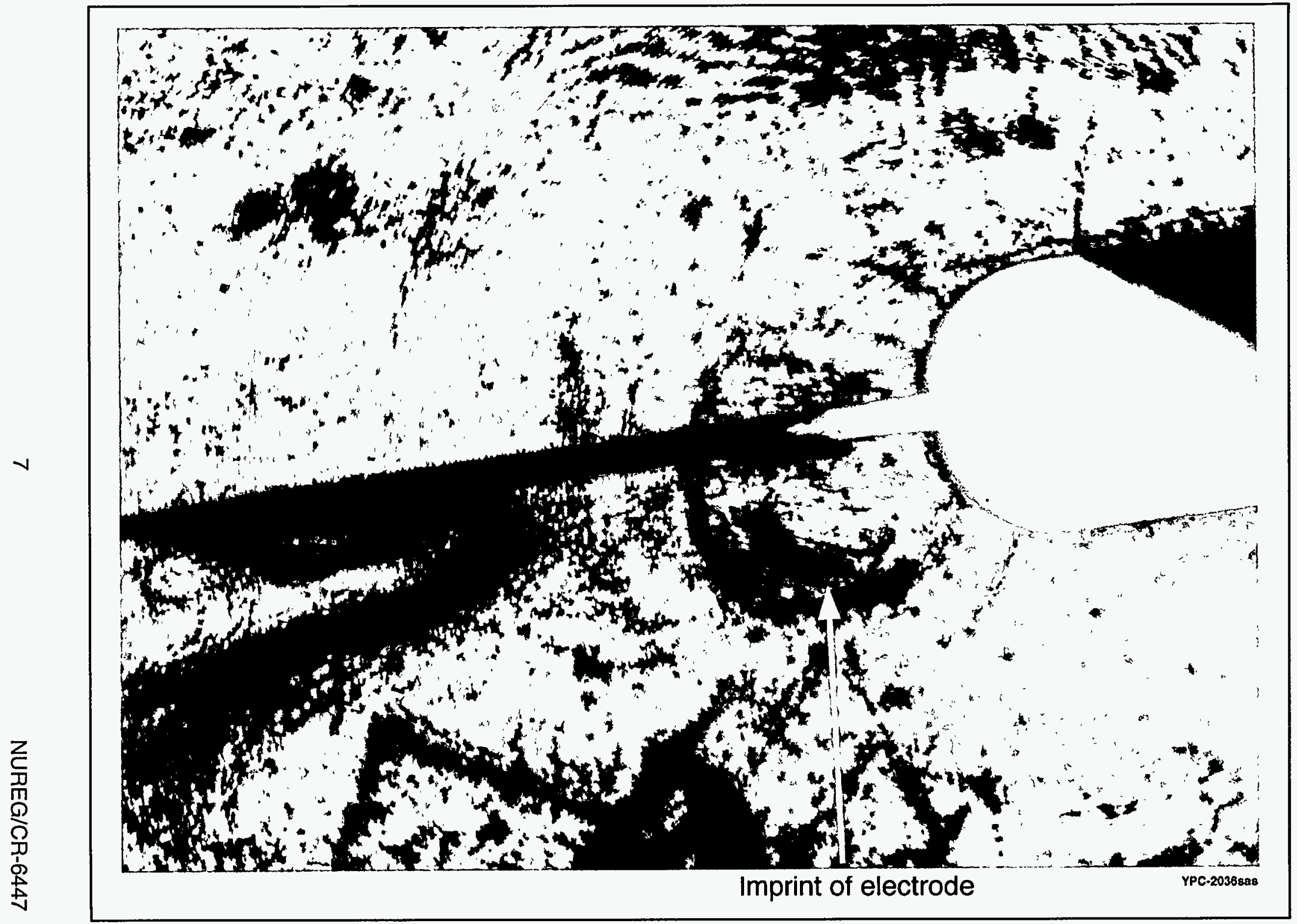

Figure 2. Irradiated crack-arrest specimen BK7 showing crack-tip region, circular imprint of the "spot-welder" electrodes, and the propagated crack at the bottom of the side grooves after test completion. 


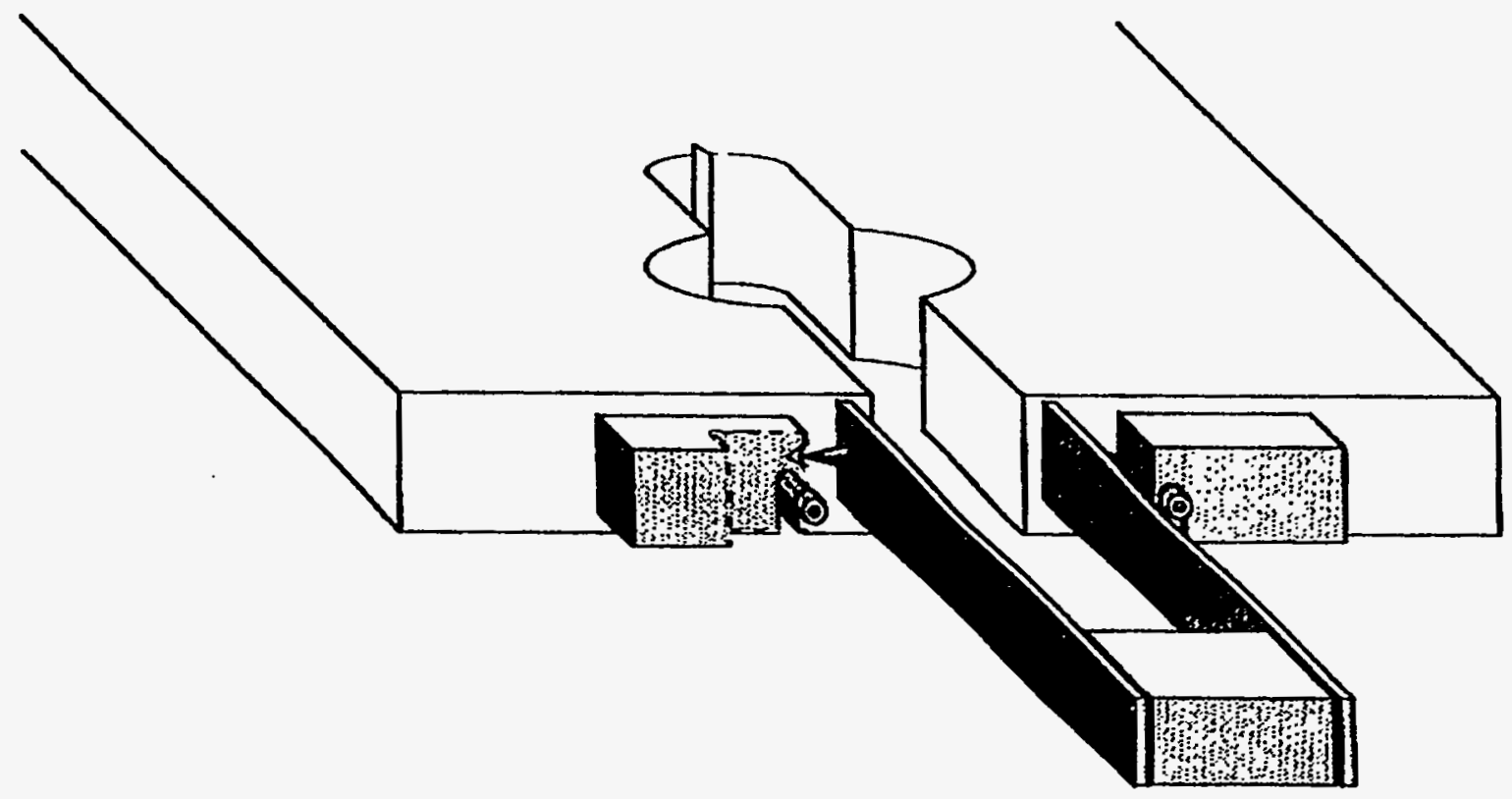

Figure 3. Perspective view of the clip gage attached to mounting blocks.

ORNL-DWG 94-13363

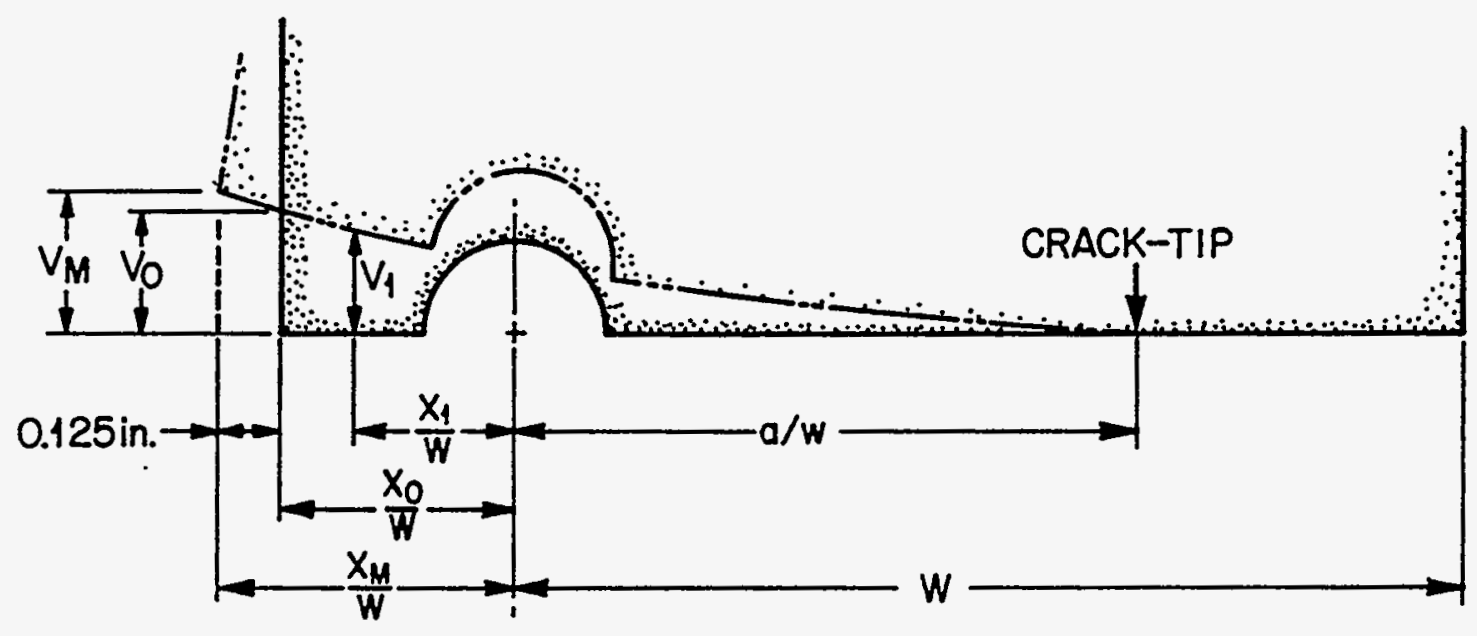

Figure 4. Locations $M, 0$, and 1 at which one-half the crack-line displacements $V_{m}, V_{0}$, and $V_{1}$, respectively, were calculated. 
The point at which the CMODs were measured in the ANPA specimens is $3.2 \mathrm{~mm}(0.125 \mathrm{in}$.) from the front face of the specimen, and results in CMODs measured at distances of 0.29 and $0.27 \mathrm{~W}$ for the small and large specimens, respectively, rather than the 0.25W prescribed in ASTM E 1221-88.

It is assumed that the crack-line displacements, at locations ranging from the $L L$ to beyond the front face of the specimen, vary linearly with distance from the $L L$." Referring to Figure 4 and recalling that:

$$
\begin{aligned}
& \frac{X_{0}}{W}=0.25, \\
& \frac{X_{1}}{W}=0.1576,
\end{aligned}
$$

and

$$
\frac{X_{M}}{W}=M
$$

Then, by using similar triangles, the following relation may be written:

$$
\frac{2 V_{M}-2 V_{0}}{M-0.25}=\frac{2 V_{0}-2 V_{1}}{0.25-0.1576}
$$

and simplifying the denominator of the right-hand side, the above equation becomes:

$$
\frac{2 V_{M}-2 V_{0}}{M-0.25}=\frac{2 V_{0}-2 V_{1}}{0.0924}
$$

where $2 V_{M}, 2 V_{0}$, and $2 V_{1}$ are the relative crack-face displacements at locations $M, 0$, and 1 , respectively, as indicated in Figure 4. Solving for the front-face displacement $V_{0}$, see Equation (9), becomes:

$$
2 V_{0}=\frac{0.0924\left(2 V_{M}\right)+\left(2 V_{1}\right)(M-0.25)}{0.0924+(M-0.25)}
$$

The crack-line displacements given by Newman are normalized with respect to the applied force, $P$, and are thus the specimen compliances at the respective locations. These compliances, $C$, are of the form:

$$
C=\frac{2 V E B}{P}
$$

This is approximately true, as can be seen in Figure 11 of ref. 20 , since this part of the specimen is not subjected to any loads. 
where $B$ is the specimen thickness, and $E$ is Young's Modulus. Solving for the relative crack-face displacement $2 \mathrm{~V}$ yields:

$$
2 V=\frac{C P}{E B}
$$

Following the method used in ASTM 1221 to account for side grooves, the above expression can be multiplied by a square-root term as follows:

$$
2 V=\frac{C P}{E B} \sqrt{\frac{B}{B_{N}}},
$$

where $B_{N}$ is the net specimen thickness at the root of the side grooves. The correction factor in Equation (13) can also be of the form $\left(B / B_{e}\right)$ where $B_{e}$ is from ASTM Standard Test Method for Determining J-R Curves (E 1152-87):

$$
B_{e}=B-\frac{\left(B-B_{N}\right)^{2}}{B}
$$

It should be noted that either form gives the same value for the adjusted CMOD, since the compliances are only used to "calibrate" the measured CMOD, but the opening force, $P$, is about $10 \%$ higher when $\left(B / B_{e}\right)$ is used rather than the $\sqrt{\left(B / B_{N}\right)}$.

The specimen compliances at locations 0 and 1, excerpted from Newman's reference, are given in Table 4. To interpolate the compliances at crack lengths other than those tabulated, the following function was regression fit to the tabulated values:

$$
C^{0.5}=A+\frac{B}{\ln \frac{a}{W}},
$$

where $A$ and $B$ are fitting parameters, and $a$ is the crack length. The parameters $A$ and $B$ are given in Table 5 , and the resulting fits are shown in Figure 5. The form of Equation (15) was chosen as the simplest from a large number of other trial candidate equations. The degree-of-freedom adjusted coefficient of determination (DOF- $r^{2}$ ) was better than 0.9999 .

The opening force, $P$, applied at the $L L$, is not directly known from the experiment, since the load recorded during the crack-arrest test is the wedge load and includes various friction forces, such as that between the wedge and the split pins. For each initiation and arrested crack depth, $a_{0} N$ and $a_{2} N$, respectively, the force $P$ was previously 
Table 4. Normalized crack-line displacements (or compliances) at specimen front face, $x=0.25 \mathrm{~W}$, and at $x=0.1576 \mathrm{~W}$ as a function of crack length (plane stress conditions and Poisson's ratio $=0.3$ were assumed)

\begin{tabular}{|c|c|c||}
\hline $\begin{array}{c}\text { Normalized crack } \\
\text { length } \\
(\mathbf{a} / \mathrm{W})\end{array}$ & $\begin{array}{c}\text { Normalized crack-line } \\
\text { displacement at } \\
\mathbf{x}=\mathbf{0 . 2 5 W} \\
\left(2 \mathrm{EBV}_{\mathrm{o}} / \mathrm{P}\right)\end{array}$ & $\begin{array}{c}\text { Normalized crack-line } \\
\text { displacement at } \\
\mathbf{x}=\mathbf{0 . 1 5 7 6 W} \\
(2 \mathrm{EBV} / \mathrm{P})\end{array}$ \\
\hline 0.20 & 12.18 & 11.15 \\
0.25 & 15.64 & 14.26 \\
0.30 & 19.90 & 18.14 \\
0.35 & 25.12 & 22.80 \\
0.40 & 31.58 & 28.64 \\
0.45 & 39.73 & 36.05 \\
0.50 & 50.33 & 45.70 \\
0.55 & 64.59 & 58.73 \\
0.60 & 84.63 & 77.07 \\
0.65 & 114.30 & 104.20 \\
0.70 & 161.00 & 147.20 \\
0.75 & 240.80 & 220.60 \\
0.80 & 392.40 & 360.20 \\
\hline Source: Excerpted from Table III, J. C. Newman, Jr., NASA Langley Research Center, Hampton, Virginia, Crack- \\
Opening Displacements in Center-Crack, Compact, and Crack-Line Wedgo-Loaded Specimens, NASA TN D-8268, July \\
1976.
\end{tabular}

Table 5. Results of regression fitting Equation (7) to the compliances at positions $\mathbf{0}$ and 1 for various crack lengths

\begin{tabular}{|l|c|c|}
\hline \multicolumn{1}{|c|}{ Position } & A & B \\
\hline 0 front face & 0.977241836225 & -4.195700426660 \\
1 intermediate & 0.888013907529 & -4.029889833442 \\
\hline
\end{tabular}




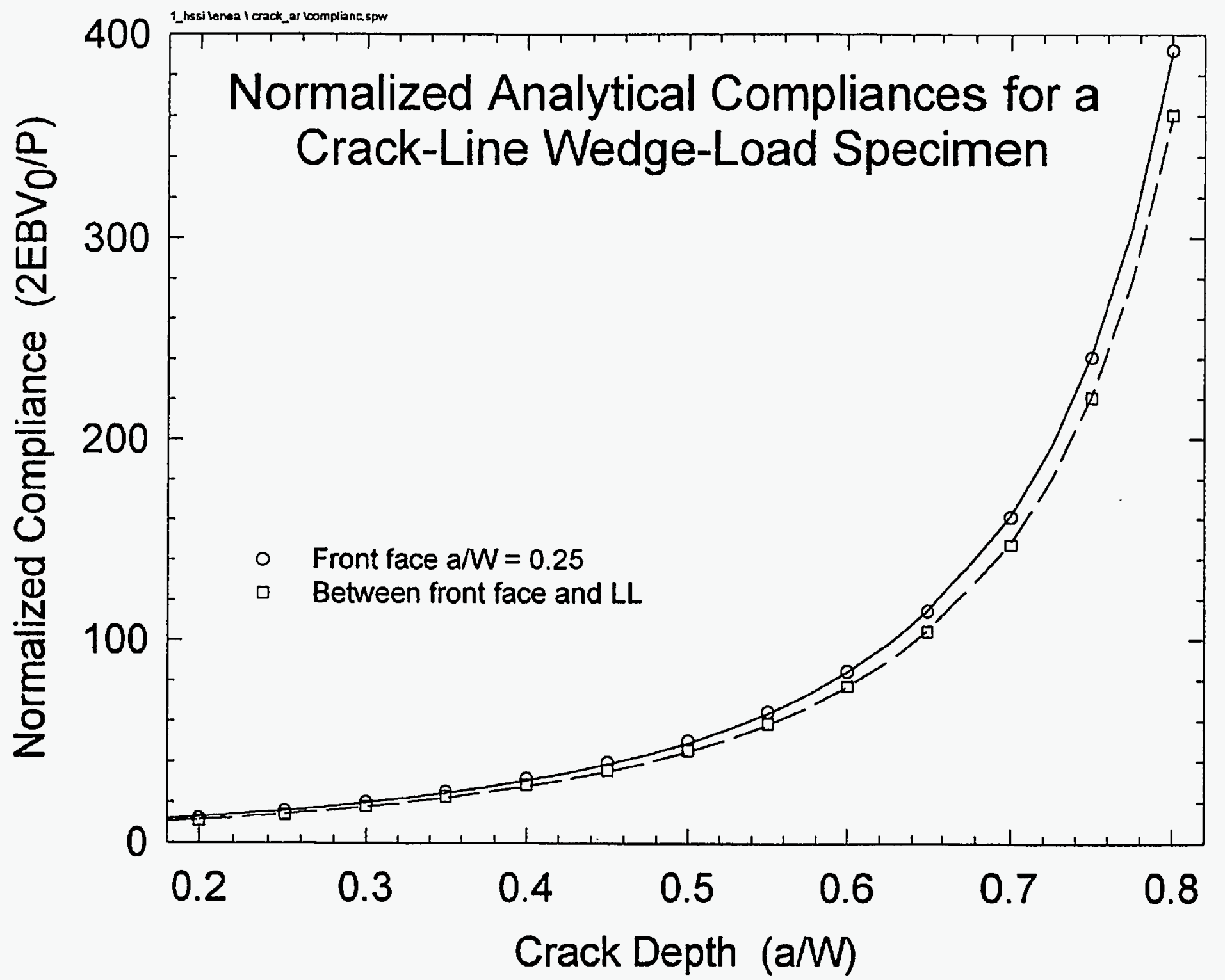

Figure 5. Crack-line wedge-loaded specimen compliances and regression fit of Equation (2.5). Source: J. C. Newman, Jr., NASA Langley Research Center, Hampton, Virginia, Crack-Opening Displacements in Center-Crack, Compact, and Crack-Line Wedge-Loaded Specimens, NASA TN D-8268, July 1976. 
calculated iteratively. However, it can be calculated in the following manner suggested by J. G. Merkle."

Equation (9) can be rewritten in the following form:

$$
0.0924\left(2 V_{M}\right)-0.0924\left(2 V_{0}\right)=(M-0.25)\left(2 V_{0}-2 V_{1}\right)
$$

Let

$$
\alpha=\frac{1}{E B} \sqrt{\frac{B}{B_{N}}},
$$

then Equation (12) may be written as

$$
2 V=C P \alpha,
$$

or

$$
\frac{2 V}{\alpha}=C P \text {, }
$$

and Equation (16), expressed in terms of the measured CMOD, compliances, specimen geometry, and the force $P$, becomes:

$$
\frac{0.0924}{\alpha} 2 V_{M}-0.0924 C_{0} P=(M-0.25)\left(C_{0}-C_{1}\right) P
$$

which may be solved for the force $P$ in terms of known quantities:

$$
P=\frac{0.0924\left(2 V_{M}\right)}{\alpha\left[(M-0.25)\left(C_{0}-C_{1}\right)+0.0924 C_{0}\right]}
$$

Using Equation (18), the front-face CMOD, $2 \mathrm{~V}_{0}$, may now be expressed in terms of the compliances and the relative distances from the $L L$ as:

$$
2 V_{0}=\frac{0.0924 C_{0}\left(2 V_{M}\right)}{\left[(M-0.25)\left(C_{0}-C_{1}\right)+0.0924 C_{0}\right]}
$$

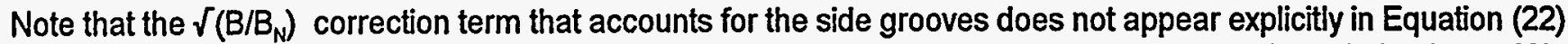
but is implicit in $2 V_{M}$. The results of the above calculations to adjust the initiation and arrested crack depths, $a_{0} M$ and $a_{a} N$, respectively, are shown in Table 6 . It may be seen that the relative difference between the measured values and the adjusted ones is $\leq 4 \%$ for the smaller and $s 2 \%$ for the larger specimens. These adjustments could

"Memorandum, J. G. Merkle, Oak Ridge National Laboratory, to S. K. Iskander, Oak Ridge National Laboratory, August 2, 1995. 
Table 6. Details of calculations to adjust the measured initiation and arrest crack-mouth opening displacement (CMOD) values to account for the $X_{M} W>0.25 W$ location at which they were measured

\begin{tabular}{|c|c|c|c|c|c|c|c|c|c|c|c|}
\hline Specimen & $\begin{array}{l}a_{0} M, \\
a_{a} M\end{array}$ & $\mathrm{C}_{0}$ & $C_{1}$ & $\underset{(k s i)}{E}$ & $\begin{array}{l}\text { Measured } \\
\text { CMOD, } \\
2 V_{M} \text { or } d_{0} \\
\text { (mils) }\end{array}$ & $\begin{array}{c}\text { B } \\
\text { (in.) }\end{array}$ & $\begin{array}{c}\text { Bn } \\
\text { (in.) }\end{array}$ & $X_{M} / W$ & $\begin{array}{c}\text { P } \\
\text { (kips) }\end{array}$ & $\begin{array}{c}2 V_{0} \text { from } \\
2 V_{M}, M, C_{0}, C_{1} \\
\text { (mils) }\end{array}$ & $\begin{array}{c}\left(V_{m}-V_{0}\right) N_{M} \\
(\%)\end{array}$ \\
\hline \multicolumn{12}{|c|}{ Initiation } \\
\hline $\begin{array}{l}\text { BK7 } \\
\text { BK8 } \\
\text { BK9 } \\
\text { BK10 } \\
\text { BK11 } \\
\text { BK12 } \\
\text { BK13 retest } \\
\text { BK16 pop-in } \\
\text { BK16 final } \\
\text { BK18 }\end{array}$ & $\begin{array}{l}0.350 \\
0.350 \\
0.350 \\
0.350 \\
0.350 \\
0.350 \\
0.350 \\
0.350 \\
0.350 \\
0.350\end{array}$ & $\begin{array}{l}24.722 \\
24.722 \\
24.722 \\
24.722 \\
24.722 \\
24.722 \\
24.739 \\
24.739 \\
24.739 \\
24.739\end{array}$ & $\begin{array}{l}22.326 \\
22.326 \\
22.326 \\
22.326 \\
22.326 \\
22.326 \\
22.341 \\
22.341 \\
22.341 \\
22.341\end{array}$ & $\begin{array}{l}29821 \\
19821 \\
29722 \\
29639 \\
29556 \\
29639 \\
29838 \\
29639 \\
30053 \\
29639 \\
\end{array}$ & $\begin{array}{l}33.3 \\
33.3 \\
30.1 \\
33.6 \\
28.2 \\
26.5 \\
80.3 \\
57.2 \\
78.3 \\
59.0 \\
\end{array}$ & $\begin{array}{l}0.492 \\
0.492 \\
0.492 \\
0.492 \\
0.492 \\
0.492 \\
0.984 \\
0.984 \\
0.984 \\
0.984\end{array}$ & $\begin{array}{l}0.378 \\
0.378 \\
0.378 \\
0.378 \\
0.378 \\
0.378 \\
0.770 \\
0.770 \\
0.770 \\
0.770\end{array}$ & $\begin{array}{l}0.290 \\
0.290 \\
0.290 \\
0.290 \\
0.290 \\
0.290 \\
0.270 \\
0.270 \\
0.270 \\
0.270 \\
\end{array}$ & $\begin{array}{l}16.633 \\
16.633 \\
14.985 \\
16.680 \\
13.961 \\
13.156 \\
82.610 \\
58.453 \\
81.134 \\
60.293 \\
\end{array}$ & $\begin{array}{l}31.97 \\
31.97 \\
28.90 \\
32.26 \\
27.08 \\
25.45 \\
78.68 \\
56.04 \\
76.72 \\
57.807 \\
\end{array}$ & $\begin{array}{l}4.0 \\
4.0 \\
4.0 \\
4.0 \\
4.0 \\
4.0 \\
2.0 \\
2.0 \\
2.0 \\
2.0 \\
\end{array}$ \\
\hline \multicolumn{12}{|c|}{ Arrest } \\
\hline $\begin{array}{l}\text { BK7 } \\
\text { BK8 } \\
\text { BK9 } \\
\text { BK10 } \\
\text { BK11 } \\
\text { BK12 } \\
\text { BK13 retest } \\
\text { BK16 pop-in } \\
\text { BK16 final } \\
\text { BK18 }\end{array}$ & $\begin{array}{l}0.617 \\
0.637 \\
0.593 \\
0.592 \\
0.616 \\
0.629 \\
0.768 \\
0.678 \\
0.903 \\
0.658\end{array}$ & $\begin{array}{r}93.155 \\
105.787 \\
81.122 \\
80.532 \\
92.623 \\
100.275 \\
283.663 \\
138.260 \\
1790.906 \\
121.239\end{array}$ & $\begin{array}{r}85.002 \\
96.593 \\
73.964 \\
73.423 \\
84.514 \\
91.535 \\
260.051 \\
126.407 \\
1648.041 \\
110.778 \\
\end{array}$ & $\begin{array}{l}29821 \\
19821 \\
29722 \\
29639 \\
29556 \\
29639 \\
29838 \\
29639 \\
30053 \\
29639\end{array}$ & $\begin{array}{l}34.5 \\
34.5 \\
31.4 \\
35.8 \\
29.2 \\
28.3 \\
88.1 \\
64.0 \\
82.8 \\
66.4 \\
\end{array}$ & $\begin{array}{l}0.492 \\
0.492 \\
0.492 \\
0.492 \\
0.492 \\
0.492 \\
0.984 \\
0.984 \\
0.984 \\
0.984\end{array}$ & $\begin{array}{l}0.378 \\
0.378 \\
0.378 \\
0.378 \\
0.378 \\
0.378 \\
0.770 \\
0.770 \\
0.770 \\
0.770\end{array}$ & $\begin{array}{l}0.290 \\
0.290 \\
0.290 \\
0.290 \\
0.290 \\
0.290 \\
0.270 \\
0.270 \\
0.270 \\
0.270 \\
\end{array}$ & $\begin{array}{r}4.584 \\
4.038 \\
4.781 \\
5.479 \\
3.867 \\
3.472 \\
7.923 \\
11.721 \\
1.189 \\
13.877 \\
\end{array}$ & $\begin{array}{l}33.21 \\
33.22 \\
30.26 \\
34.52 \\
28.10 \\
27.23 \\
86.52 \\
62.80 \\
81.42 \\
65.202 \\
\end{array}$ & $\begin{array}{l}3.6 \\
3.6 \\
3.6 \\
3.6 \\
3.6 \\
3.6 \\
1.7 \\
1.8 \\
1.7 \\
1.8 \\
\end{array}$ \\
\hline
\end{tabular}


also be estimated by assuming that the rotation point for the specimens is at the tip of the flaw and was approximately the same as those obtained using the above procedure. However, the errors of the latter procedure would have been unknown.

\subsection{Crack-Arrest Toughness Values of Unirradiated and Irradiated Specimens}

The crack-arrest toughness $\left(K_{2}\right)$ of the unirradiated specimens, which were tested by ANPA from 1986 to 1987, are given in Table 7. The thickness of the specimens used in these unirradiated tests ranged from 12.5 to $50 \mathrm{~mm}$. The test temperatures, which ranged from -20 to $40^{\circ} \mathrm{C}$, were also normalized with respect to the reference temperature, $R T_{\text {NDT }}$, of $-12.5^{\circ} \mathrm{C}\left(10^{\circ} \mathrm{F}\right)$; both are also given in Table 7. In accordance with Subarticle NB-2330 of the 1986 Edition of ASME Boiler and Pressure Vessel Code, Sect. III, RT $\mathrm{NDT}_{\text {T }}$ is the highest of three temperatures: $T_{N D r}, T_{C V N-68 \mathrm{~J}}-33$, and $T_{L E-89 m m}-33$, where $T_{N D T}$ is the drop weight nil-ductility-transition temperature (DWT-NDT), $T_{C V N-68 \mathrm{~J}}$ is the temperature at which the CVN impact energy is $68 \mathrm{~J}(50 \mathrm{ft}-\mathrm{Ib})$, and $T_{\mathrm{LE}-89 \mathrm{~mm}}$ is the temperature at which the CVN lateral expansion (LE) is $0.89 \mathrm{~mm}$ ( 35 mils). The temperatures are in ${ }^{\circ} \mathrm{C}$, and the CVN specimens must be in the T-L orientation. The $R T_{\text {NOT }}$ was determined by Terni, the Italian steel manufacturer that produced the forging. The DWT and crack-arrest specimens were machined from the same region of the forging. The DWT-NDT, $T_{\text {NDT, }}$ was determined by Terni to be $-12.5^{\circ} \mathrm{C}$. Two sets, each set consisting of three $T-L$ orientation $\mathrm{CVN}$ specimens, were tested at $\mathrm{T}_{\mathrm{NDT}}+33^{\circ} \mathrm{C}$. The results indicated that the $68-\mathrm{J}$ energy criterion was easily met. The minimum CVN impact energy from all six tests was $124 \mathrm{~J}$, and the average energy of each set was 141 and $132 \mathrm{~J}$, respectively. The LE values for these six specimens are not available. In order to estimate the LE, the CVN impact energy was plotted against the LE from the test results on specimens in the T-L orientation (see Figure 6). It may be seen that at the $124-J$ energy level the $L E$ is $\gg 0.89 \mathrm{~mm}$. Thus, the $0.89-\mathrm{mm}$ criterion was also met, and the $R T_{N D T}$ is $-12.5^{\circ} \mathrm{C}$, and was dictated by the DWT test results.

Table 7 also shows which of the five ASTM E 1221-88 validity criteria were fulfilled. These criteria are described in Table 8, and a ratio $\geq 1$ in Table 7 indicates that the particular criterion is met. In cases were a criterion fails to meet the ASTM requirements, its closeness to a value of one allows some judgment to be made about the margin with which it failed to meet the respective criterion. This is the first edition of the crack-arrest standard, and the validity criteria may be overly conservative; hence, it is of value to indicate the degree with which all five criteria are met. It is possible that useful data be obtained for a specimen without all five criteria being met. Such was the case with the results of the unirradiated and irradiated crack-arrest tests performed in the Sixth HSSI Series. ${ }^{9,10}$ The design of large structural tests was successfully performed using "invalid data." ${ }^{.11}$ It is interesting to note that all 12 specimens have met the crack-jump length validity criteria $D$ and $E$. This indicates that the ANPA crack-tip embrittling technique is successful since other crack-starter preparation techniques often produce a tough heat-affected zone that prevents the crack from propagating into the test section. ${ }^{22}$

The unirradiated specimen crack-arrest toughness values, $\left(K_{2}\right)$, have been plotted in Figure 7 . In Figure 7 , a distinction has been made between $K_{1 a}$ data, which fulfill all five ASTM 1221 validity criteria, and $K_{a}$ data, which only partially fulfill the validity criteria. It may be seen that no obvious differences between the two are apparent. This is further evidence that the five ASTM E1221 criteria may be overly conservative. The ASME $\mathrm{K}_{\mathrm{ta}}$ curve, indexed to an $R T_{N D T}=-12.5^{\circ} \mathrm{C}$, has also been plotted in Figure 7. The ASME $K_{t_{2}}$ equation, in SI units, is:

$$
K_{1 a}=29.4+13.675 \exp \left[0.0261\left(T-R T_{N D T}\right)\right] \text {, }
$$

"The previous ASME equation was:

$$
\mathrm{K}_{\mathrm{l}}=29.4+1.344 \exp \left[0.0261\left(\mathrm{~T}-\mathrm{RT}_{\mathrm{NDT}}+89\right)\right] \text {. }
$$

The new ASME equation given in the December 31, 1992, addenda of the ASME Boiler Pressure and Vessel Code did not change the curve but has simply factored out the constant "89" in the exponent. The equation is based on the one appearing in WRC Bulletin 175 (August 1972), with NDT replacing $\mathrm{RT}_{\mathrm{NDT}}$. 
Table 7. Crack-arrest toughness values for unirradiated $A 508$ class 3 forging material with an $R T_{\text {NDT }}=-12.5^{\circ} \mathrm{C}$ (all unirradiated crack-arrest tests conducted by ANPA)

\begin{tabular}{|c|c|c|c|c|c|c|c|c|c|c|}
\hline \multirow{2}{*}{ Specimen } & \multirow{2}{*}{$\begin{array}{l}\text { Thickness } \\
\text { (mm) }\end{array}$} & \multirow{2}{*}{$\begin{array}{c}\text { Test } \\
\text { temperature } \\
\left({ }^{\circ} \mathrm{C}\right)\end{array}$} & \multirow{2}{*}{$\begin{array}{l}T-R T_{\text {NDT }} \\
\left({ }^{\circ} \mathrm{C}\right)\end{array}$} & \multirow{2}{*}{$\begin{array}{c}\mathrm{K}_{\mathrm{a}} \\
(\mathrm{MPa} \sqrt{\mathrm{m}})\end{array}$} & \multicolumn{5}{|c|}{$\begin{array}{l}\text { Valid according to ASTM E 1221-88 if } \\
21 \text { for each of the following criteria }\end{array}$} & \multirow{2}{*}{$\begin{array}{l}\text { Valid } \\
\text { for all } \\
\text { criteria }\end{array}$} \\
\hline & & & & & A & B & C & D & $\mathbf{E}$ & \\
\hline
\end{tabular}




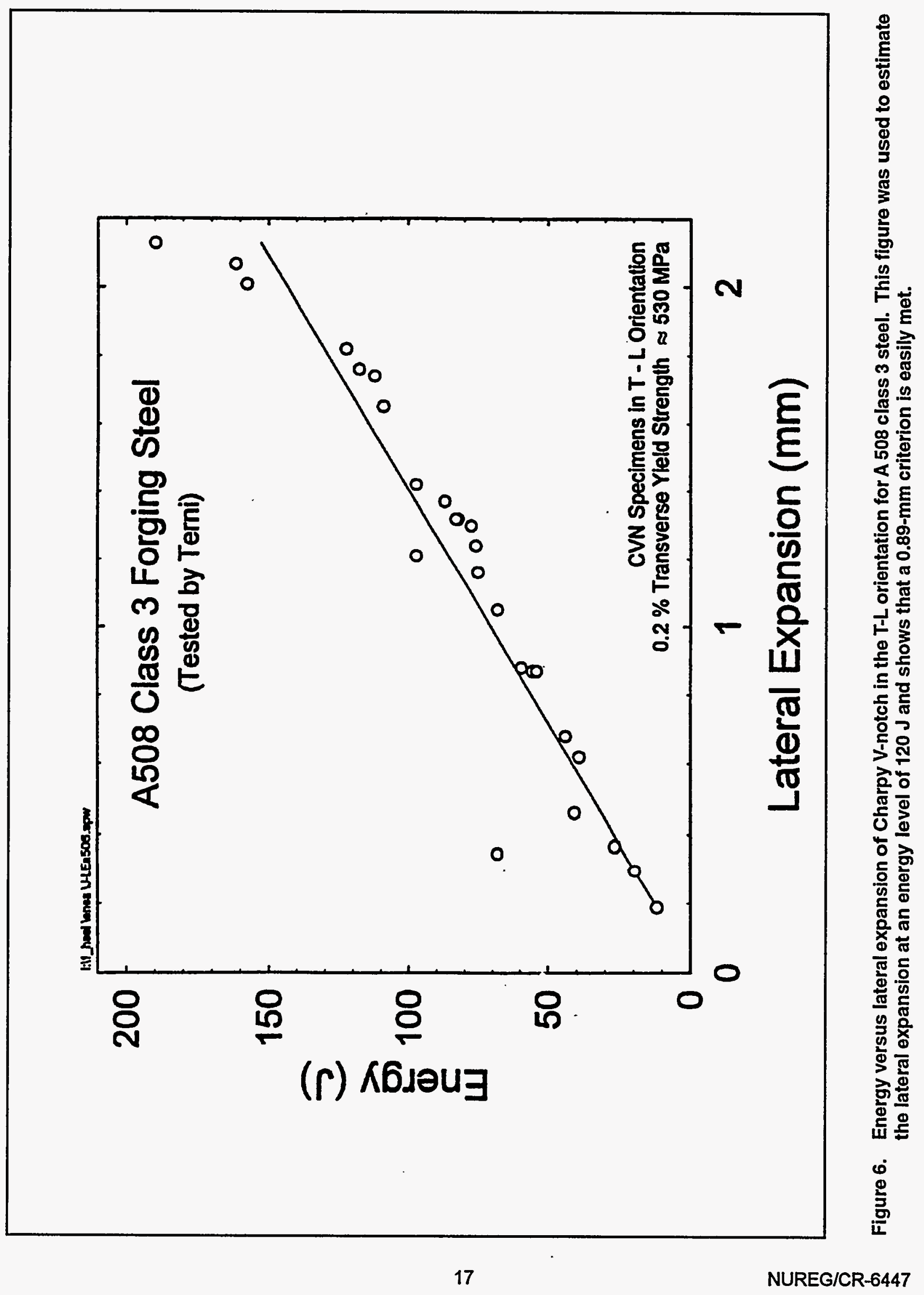


Table 8. Validity criteria (from ASTM E 1221-88) used to ensure that $K_{a}$ is a linear elastic, plane-strain value (symbols and nomenclature of $E$ 1221-88 have also been adopted)

\begin{tabular}{|c|c|c|}
\hline \multicolumn{2}{|r|}{ Feature } & Criterion $^{a}$ \\
\hline \multicolumn{2}{|c|}{$\begin{array}{l}\text { Unbroken ligament } \\
\text { Unbroken ligament } \\
\text { Thickness } \\
\text { Crack jump length } \\
\text { Crack jump length }\end{array}$} & $\begin{array}{l}\text { A. } W-a_{a} \geq 0.15 W \\
\text { B. } W-a_{a} \geq 1.25\left(K_{a} / \sigma_{Y d}\right)^{2} \\
\text { C. } B \geq 1.0\left(K_{a} / \sigma_{Y d}\right)^{2} \\
\text { D. } a_{a}-a_{a} \geq 2 N \\
\text { E. } a_{a}-a_{0} \geq\left(K_{d} / \sigma_{Y d}\right)^{2} / 2 \pi\end{array}$ \\
\hline \multicolumn{3}{|r|}{$\begin{array}{l}\text { imen, } \\
\text { centerline of loading hole to furthest edge of crack-starter } \\
\text { mate for appropriate loading times at the test temperature [for } \\
205 \mathrm{MPa}(30 \mathrm{ksi}) \text { greater than } \sigma_{y} \text { ], } \\
\text { material (or, in the case of a duplex specimen, of the } \\
\text { hortly after arrest, } \\
\text { crack initiation. }\end{array}$} \\
\hline
\end{tabular}

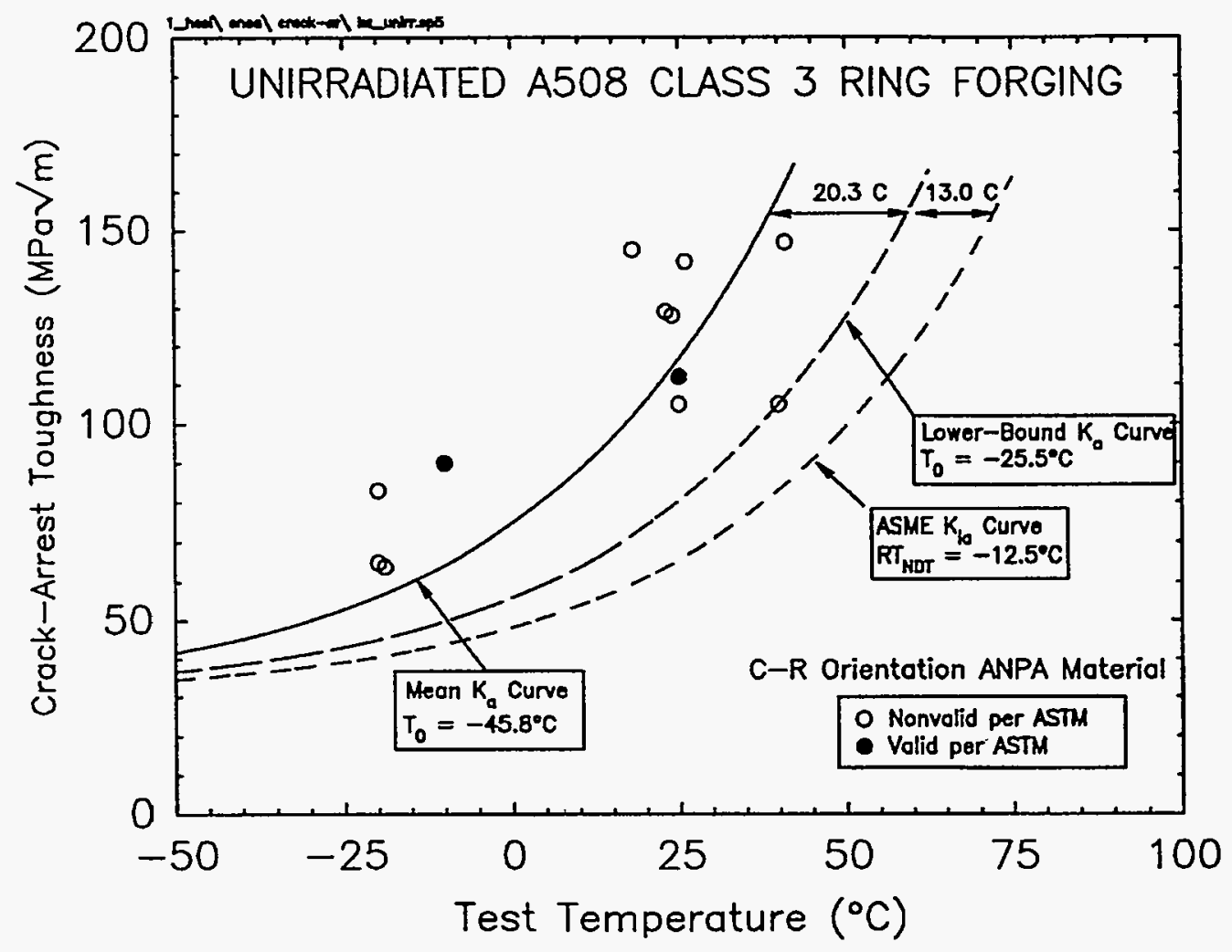

Figure 7. Crack-arrest toughness values $\left(K_{\mathrm{a}}\right)$ of unirradiated $A 508$ class 3 forging material with an $R_{T} T_{N D T}=-12.5^{\circ} \mathrm{C}$, together with the lower bound and the ASME $K_{1 \mathrm{a}}$ curves. A distinction is made between $K_{\mathrm{la}}$ values that satisfy all five ASTM E 1221-88 validity criteria that ensure plane-strain conditions are met, and $K_{\mathrm{a}}$ values that do not meet all five criteria. 
where $K_{12}$ is the crack-arrest toughness in MPa $\sqrt{\mathrm{m}}$, and $\mathrm{T}$ is the test temperature in ${ }^{\circ} \mathrm{C}$. The second curve, labeled as the "Mean $K_{a}$ Curve" on the same figure, is based on the ASME $K_{12}$ curve and is of the following form:

$$
K_{a}=29.4+13.675 \exp \left[0.0261\left(T-T_{0}\right)\right] \text {. }
$$

Here, $T_{0}$ is a parameter obtained by nonlinear regression through all the data points. Thus, this curve may be interpreted as a mean curve in the least-squares sense. This mean curve will be used to adjust the irradiated data to a common irradiation temperature and fluence, as will be described below. The difference between the $T_{0}$ for the irradiated and unirradiated curves may also be used as a measure of the average shift of the crack-arrest toughness, and then compared to the shift at 41-J energy level for CVN specimens. The third curve in Figure 7 is a lower-bound curve that is also based on the ASME $K_{12}$ curve and may be thought to be obtained by shifting the ASME curve toward a lower temperature until it passes through the first data value that is encountered. The $T_{0}$ value for the curve is actually obtained by calculating it, using the temperature and $K_{2}$ values for the data point that lies on the lowest bound curve in the following expression:

$$
T_{0}=T-\frac{\ln \frac{\left(K_{a}-29.4\right)}{13.675}}{0.0261} .
$$

As mentioned previously, the testing of the irradiated specimens was performed at ORNL and closely coordinated with ANPA and Battelle. The testing of all nine irradiated specimens was performed in the inverted position. The tests were conducted at a sufficiently high temperature that the results should be unaffected by the split-pin configuration. ${ }^{23}$ The results of the irradiated tests are given in Table 9 and are presented in the order in which they were tested. Results have not been sorted with respect to test temperature because the test temperature will be adjusted as described below. The toughness of the crack-arrest specimens is plotted in Figure 8 as a function of test temperature. The ASME $K_{1 a}$ curve was also plotted on Figure 8 for an $R T_{\text {NOT }}=-1.5^{\circ} \mathrm{C}$ that was obtained from the shift at the 41-J energy level for CVN specimens irradiated to $3.2 \times 10^{19}$ neutrons $/ \mathrm{cm}^{2}(>1 \mathrm{MeV})$ and an irradiation temperature of $284^{\circ} \mathrm{C}$. As may be seen in Table 7, there are significant differences in the irradiation temperatures and fluences between the crack-arrest specimens, and in order to account for these differences and to compare the CVN shift to that of the crack-arrest specimens due to irradiation, an adjustment was made as explained below.

The difference between the test temperature of each specimen and that corresponding to the $K_{2}$ toughness value on the unirradiated ASME $K_{12}$ curve is the basis used to adjust the values of the test temperatures to account for the variations in irradiation temperature and irradiation fluence. As may be seen in Figure 8 , there are two $K_{2}$ points either on or below the ASME curve. This is most likely due to the low irradiation temperature for these sperimens.

Complete details of the specimen dimensions and pretest and post-test data are given in Appendix C. The X-Y plotter output from these tests and the fracture surfaces of the irradiated specimens are given in Appendix D. The uneven crack front of the arrested crack, as well as the unbroken ligaments, is probably the largest source of error in the calculation of the crack-arrest toughness values. It has been estimated that an error of approximately \pm 1 to $2 \%$ in the measurement of the length of the arrested crack length can lead to an error of 5 to $10 \%$ in the calculated $\mathrm{K}_{\mathrm{a}}$ value.?

This $T_{0}$ should not be confused with the reference temperature used in the ASTM Test Practice (Method) for Fracture Toughness in the Transition Range, Draft 9, May 2, 1995. 
Table 9. Results of testing irradiated crack-arrest specimens machined from A 508 class 3 forging material

\begin{tabular}{|c|c|c|c|c|c|c|c|c|c|c|c|c|}
\hline \multirow{3}{*}{ Specimen } & \multicolumn{2}{|c|}{ Exposure values } & \multirow{3}{*}{$\begin{array}{c}\text { Test } \\
\text { temperature } \\
\left({ }^{\circ} \mathrm{C}\right)\end{array}$} & \multicolumn{4}{|c|}{ Stress-intensity factors } & \multicolumn{5}{|c|}{ ASTM validity criteria" } \\
\hline & \multirow{2}{*}{$\begin{array}{c}\text { Irradiation } \\
\text { temperatur } \\
\text { e } \\
\left({ }^{\circ} \mathrm{C}\right)\end{array}$} & \multirow{2}{*}{$\begin{array}{c}\text { Fluence, } \\
>1 \mathrm{MeV} \\
\left(10^{10} \mathrm{n} / \mathrm{cm}^{2}\right)\end{array}$} & & \multicolumn{2}{|c|}{ Initiation, $\mathrm{K}_{0}$} & \multicolumn{2}{|c|}{ Arrest, $\mathrm{K}_{\mathrm{a}}$} & \multirow{2}{*}{ A } & \multirow{2}{*}{$\mathbf{B}$} & \multirow{2}{*}{ c } & \multirow{2}{*}{ D } & \multirow{2}{*}{$\mathbf{E}$} \\
\hline & & & & (ksivin.) & $(\mathrm{MPa} / \mathrm{m})$ & (ksivin.) & $(\mathrm{MPa} / \mathrm{m})$ & & & & & \\
\hline \multicolumn{13}{|c|}{ 12.5-mm-thick specimens } \\
\hline $\begin{array}{l}\text { BK7 } \\
\text { BK8 } \\
\text { BK9 } \\
\text { BK10 } \\
\text { BK11 } \\
\text { BK12 } \\
\end{array}$ & $\begin{array}{l}272 \\
265 \\
268 \\
271 \\
244 \\
243 \\
\end{array}$ & $\begin{array}{l}2.5 \\
2.2 \\
2.5 \\
2.2 \\
1.8 \\
1.8\end{array}$ & $\begin{array}{l}28 \\
28 \\
40 \\
50 \\
60 \\
50\end{array}$ & $\begin{array}{l}151.8 \\
151.8 \\
136.8 \\
152.3 \\
127.4 \\
120.1\end{array}$ & $\begin{array}{l}166.8 \\
166.8 \\
150.3 \\
167.4 \\
140.0 \\
132.0\end{array}$ & $\begin{array}{r}98.0 \\
93.9 \\
93.3 \\
106.4 \\
82.3 \\
77.9\end{array}$ & $\begin{array}{r}107.7 \\
103.2 \\
102.5 \\
116.9 \\
90.4 \\
85.6\end{array}$ & $\begin{array}{l}2.56 \\
2.42 \\
2.71 \\
2.72 \\
2.56 \\
2.58\end{array}$ & $\begin{array}{l}1.05 \\
1.08 \\
1.21 \\
0.93^{b} \\
1.44 \\
1.57\end{array}$ & $\begin{array}{l}0.54^{b} \\
0.58^{b} \\
0.58^{b} \\
0.44^{b} \\
0.73^{b} \\
0.83^{b}\end{array}$ & $\begin{array}{l}1.33 \\
1.44 \\
1.22 \\
1.21 \\
1.33 \\
1.39\end{array}$ & $\begin{array}{l}1.19 \\
1.29 \\
1.32 \\
1.04 \\
1.61 \\
1.93\end{array}$ \\
\hline \multicolumn{13}{|c|}{ 25-mm-thick specimens } \\
\hline $\begin{array}{l}\text { BK13 retest } \\
\text { BK16 pop-in } \\
\text { BK16 final } \\
\text { BK18 }\end{array}$ & $\begin{array}{l}280 \\
280 \\
280 \\
274\end{array}$ & $\begin{array}{l}2.7 \\
2.7 \\
2.7 \\
2.3\end{array}$ & $\begin{array}{r}26 \\
50 \\
0 \\
50\end{array}$ & $\begin{array}{l}261.9 \\
185.3 \\
257.2 \\
191.1\end{array}$ & $\begin{array}{l}287.8 \\
203.6 \\
257.2 \\
210.0\end{array}$ & $\begin{array}{r}125.4 \\
113.2 \\
70.8 \\
122.7\end{array}$ & $\begin{array}{r}137.8 \\
124.4 \\
77.8 \\
134.8\end{array}$ & $\begin{array}{l}1.55 \\
2.15 \\
0.64^{b} \\
2.28\end{array}$ & $\begin{array}{l}0.78^{\circ} \\
1.29 \\
1.05 \\
1.17\end{array}$ & $\begin{array}{l}0.66^{b} \\
0.78^{b} \\
2.12^{b} \\
0.67^{b}\end{array}$ & $\begin{array}{l}2.09 \\
1.64 \\
2.77 \\
1.54\end{array}$ & $\begin{array}{l}1.26 \\
1.90 \\
1.80 \\
1.68\end{array}$ \\
\hline
\end{tabular}




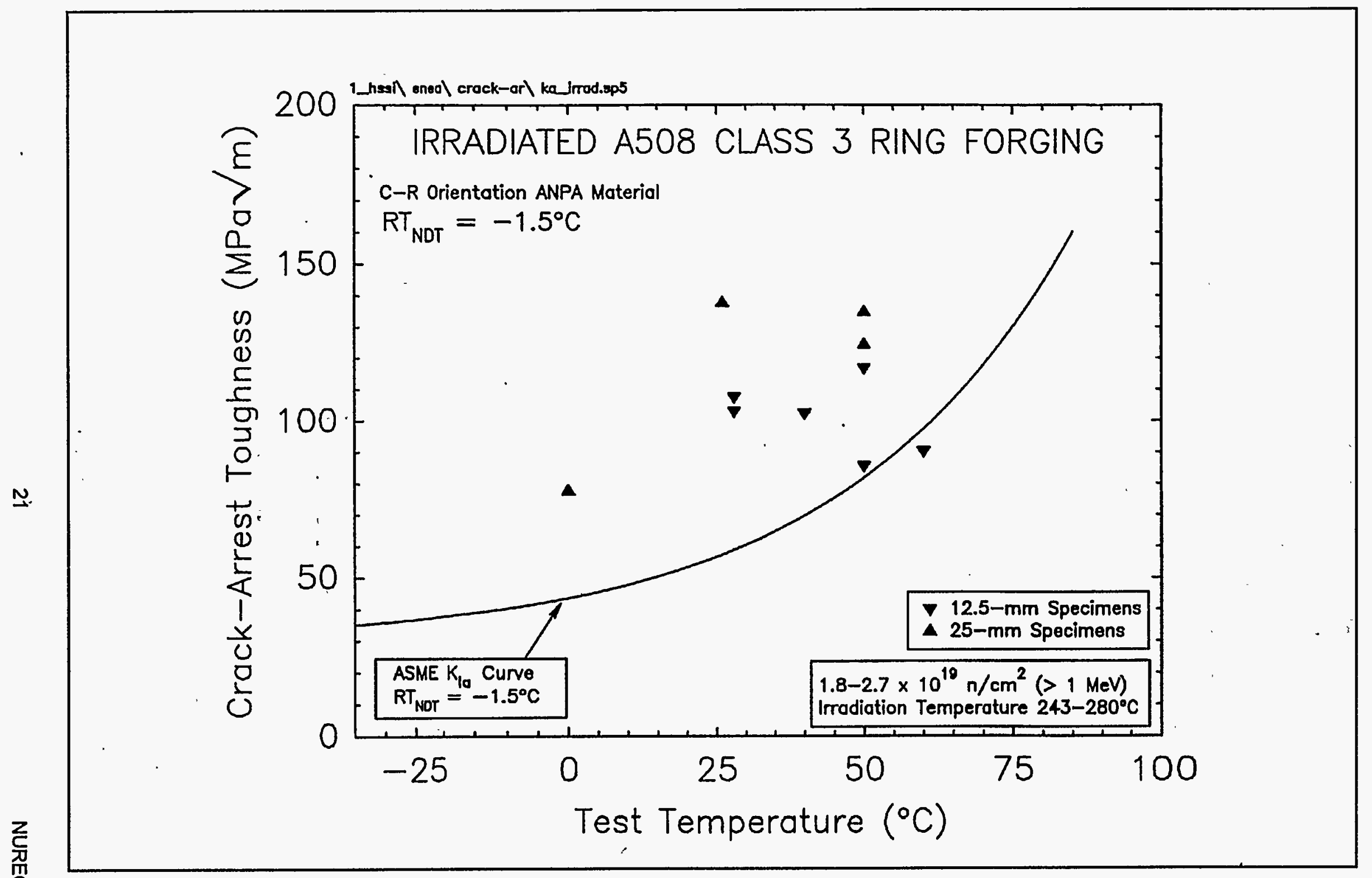

Figure 8. Crack-arrest toughness values $\left(K_{\mathrm{e}}\right)$ vs test temperature of irradiated A 508 class 3 forging material with an $\mathrm{RT}_{\text {NDT }}=-1.5^{\circ} \mathrm{C}$. The points near or below the ASME $K_{1 e}$ curve are due to the low irradiation temperature of these two specimens compared to the other specimens. 


\subsection{Adjustment to Account for Differences in Irradiation Temperature and Exposure}

To account for the different exposure parameters of each specimen, the test data have been referenced to the fluence and irradiation temperature of the CVN specimens irradiated in the same capsule as the crack-arrest specimens, thus reducing spectrum effects. The fluence for these CVN data is $3.2 \times 10^{19}$ neutrons $/ \mathrm{cm}^{2}(>1 \mathrm{MeV})$, and the irradiation temperature is $284^{\circ} \mathrm{C}$. The data were "adjusted" using observations from Odette. ${ }^{24}$ The test temperatuie was decreased by $1^{\circ} \mathrm{C}$ for every $1^{\circ} \mathrm{C}$ of irradiation temperature less than the reference temperature and vice versa, i.e., an adjustment of $\pm 1^{\circ} \mathrm{C}$ to the test temperature per $\pm 1^{\circ} \mathrm{C}$ difference in irradiation temperature.

Odette's observations were also used to adjust the actual fluence to the reference fluence by first determining the temperature shift at the measured $\mathrm{K}_{\mathrm{a}}$ level, $\Delta \mathrm{TK}_{\mathrm{a}}$, between the test temperature and the mean unirradiated $\mathrm{K}_{2}$ curve as given in Equation (24). An adjusted shift was then calculated as follows:

$$
\Delta \operatorname{TK}_{\mathrm{a}}^{\prime}=\Delta \operatorname{TK}_{\mathrm{a}}\left(\frac{\Phi^{\prime}}{\Phi}\right)^{0.5}
$$

where

$$
\begin{aligned}
\Delta T K^{\prime} & =\text { shift adjusted to the reference fluence, } \Phi^{\prime} \\
\Delta T K_{\mathrm{a}} & =\text { shift between the test temperature and the mean unirradiated curve, } \\
\Phi^{\prime} & =\text { the reference fluence, } 3.2 \times 10^{19} \text { neutrons } / \mathrm{cm}^{2}(>1 \mathrm{MeV}) \\
\Phi & =\text { the fluence of the specimen. }
\end{aligned}
$$

The adjusted test temperature, $T^{\prime}$, was then calculated as follows:

$$
T^{\prime}=T+\left(\Delta T_{K_{a}^{\prime}}-\Delta T K_{a}\right)+\left(T_{\text {irr }}-T_{\text {ref }}\right)
$$

where

$$
\begin{aligned}
T_{1} & =\text { adjusted test temperature } \\
T & =\text { actual test temperature, } \\
T_{\text {irt }} & =\text { temperature at which the specimen was irradiated, } \\
T_{\text {ret }} & =\text { reference temperature, } 284^{\circ} \mathrm{C} .
\end{aligned}
$$

The details of the test temperature adjustment calculations are given in Table 10, and the effect of the above adjustments on the distribution of the crack-arrest values with respect to the ASME $K_{1 a}$ curve may be seen in Figure 9. In all cases, the adjusted temperature is less than the actual test temperature. In particular, the two points that were close to or below the ASME $K_{\mathrm{fa}}$ curve are now at about the same relative distance from the curve as the rest of the data. The results of the tests on the nine irradiated crack-arrest specimens have been summarized in Table 11, which shows the adjusted temperature and the crack-arrest fracture toughness $K_{2}$.

The fit of a mean curve, see Equation (24), to the ten irradiated and test temperature-adjusted specimen crackarrest toughness values using the same computer-based method used to fit the unirradiated specimen data was not satisfactory, probably due to the scatter of the data. A fit was obtained by first choosing a trial $T_{0}$, then calculating the algebraic sum of the differences in $\mathrm{K}_{\mathrm{a}}$ between the specimen toughness and that of the trial mean curve. From tl. e trial $T_{0} \mathrm{~s}$, the value of $-37.6^{\circ} \mathrm{C}$ was chosen since it gave a sum of approximately zero to the desired precision."

"This is the same process performed by computer codes that implement least-squares regression fitting. 
Table 10. Details of the adjustment of testing temperature to a reference temperature of $284^{\circ} \mathrm{C}$ and a fluence of $3.2 \times 10^{19}$ neutrons $/ \mathrm{cm}^{2}(>1 \mathrm{MeV}$ ) for the irradiated A 508 class 3 forging crack-arrest specimens

\begin{tabular}{|c|c|c|c|c|c|c|c|c|c|c|}
\hline \multirow[b]{2}{*}{ Specimen } & \multicolumn{2}{|c|}{ Exposure values } & \multirow{2}{*}{$\begin{array}{c}\text { Test } \\
\text { temperature, } \\
\mathrm{T}\left({ }^{\circ} \mathrm{C}\right)\end{array}$} & \multirow{2}{*}{$\begin{array}{c}\text { Crack-arrest } \\
\text { toughness } \\
\text { (MPa } \sqrt{ } \text { ) }\end{array}$} & \multirow{2}{*}{$\begin{array}{l}\text { Shift from } \\
\text { mean } \\
\text { unirradiated } \\
\text { curve } \\
\text { (C) }\end{array}$} & \multirow{2}{*}{$\begin{array}{l}\text { Shift } \\
\text { adjusted } \\
\text { for fluence } \\
\text { (C) }\end{array}$} & \multirow{2}{*}{$\begin{array}{l}\text { Adjustment } \\
\text { due to } \\
\text { fluence } \\
\text { (C) }\end{array}$} & \multirow{2}{*}{$\begin{array}{l}\text { Adjustment } \\
\text { due to } \\
\text { irradiation } \\
\text { temperature } \\
\text { (C) }\end{array}$} & \multirow{2}{*}{$\begin{array}{l}\text { Adjusted } \\
\text { shift } \\
\text { (C) }\end{array}$} & \multirow{2}{*}{$\begin{array}{c}\text { Adjusted } \\
\text { test } \\
\text { temperature, } \\
T\left({ }^{\circ} \mathrm{C}\right)\end{array}$} \\
\hline & $\begin{array}{l}\text { Irradiation } \\
\text { temperature } \\
\left({ }^{\circ} \mathrm{C}\right)\end{array}$ & $\begin{array}{c}\text { Fluence, } \\
>1 \mathrm{MeV} \\
\left(10^{19} \mathrm{n} / \mathrm{cm}^{2}\right)\end{array}$ & & & & & & & & \\
\hline $\begin{array}{l}\text { BK7 } \\
\text { BK8 } \\
\text { BK9 } \\
\text { BK10 } \\
\text { BK11 } \\
\text { BK12 } \\
\text { BK13 retest } \\
\text { BK16 pop-in } \\
\text { BK final } \\
\text { BK18 }\end{array}$ & $\begin{array}{l}272 \\
265 \\
268 \\
271 \\
244 \\
243 \\
280 \\
280 \\
280 \\
274\end{array}$ & $\begin{array}{l}2.5 \\
2.2 \\
2.5 \\
2.2 \\
\cdot 1.8 \\
1.8 \\
-\quad 2.7 \\
2.7 \\
2.7 \\
2.3\end{array}$ & $\begin{array}{r}28 \\
28 \\
40 \\
50 \\
60 \\
50 \\
26 \\
50 \\
0 \\
50\end{array}$ & $\begin{array}{r}107.7 \\
103.2 \\
102.5 \\
116.9 \\
90.4 \\
85.6 \\
137.8 \\
124.4 \\
77.8 \\
134.8\end{array}$ & $\begin{array}{r}7.14 \\
9.41 \\
21.78 \\
24.89 \\
48.71 \\
41.85 \\
-7.32 \\
21.74 \\
-2.43 \\
17.76\end{array}$ & $\begin{array}{r}8.08 \\
11.35 \\
24.64 \\
30.01 \\
64.94 \\
55.80 \\
-7.97 \\
23.66 \\
-2.64 \\
20.94\end{array}$ & $\begin{array}{r}0.94 \\
1.94 \\
2.86 \\
5.13 \\
16.24 \\
13.95 \\
0.65 \\
1.93 \\
0.22 \\
3.19\end{array}$ & $\begin{array}{r}-12.0 \\
-19.0 \\
-16.0 \\
-13.0 \\
-40.0 \\
-41.0 \\
-4.0 \\
-4.0 \\
-4.0 \\
-10.0\end{array}$ & $\begin{array}{r}-11.1 \\
-17.1 \\
-13.1 \\
-7.9 \\
-23.8 \\
-27.1 \\
-3.4 \\
-2.1 \\
-3.8 \\
-6.8\end{array}$ & $\begin{array}{l}16.9 \\
10.9 \\
26.9 \\
42.1 \\
36.2 \\
22.9 \\
22.6 \\
47.9 \\
-3.8 \\
43.2\end{array}$ \\
\hline
\end{tabular}




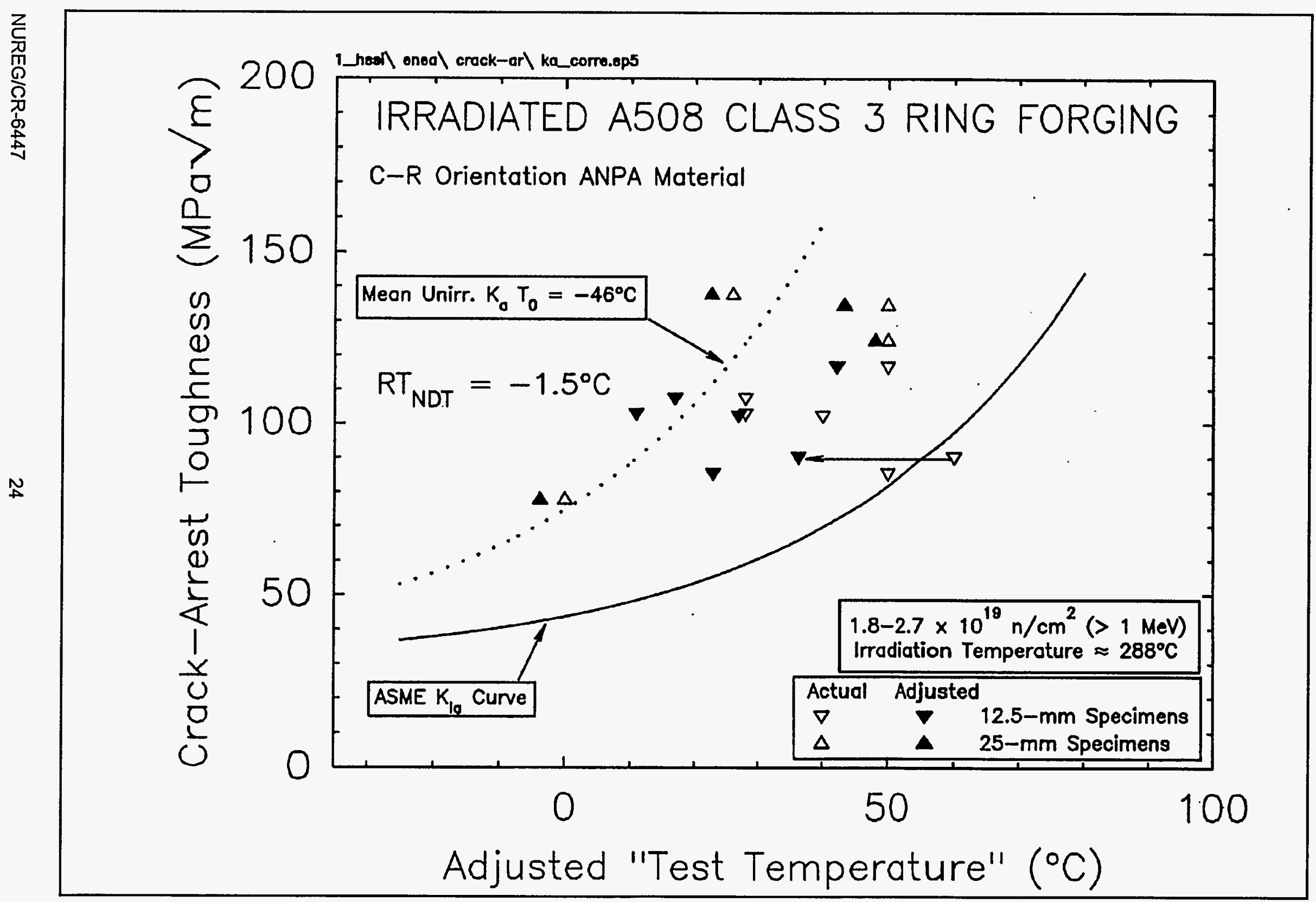

Figure 9. Effect of the test temperature adjustment on the distribution of the crack-arrest toughness with respect to the ASME $K_{\mathrm{la}}$ curve. The arrow is one example of a typical adjustment. 
Table 11. Results of testing irradiated crack-arrest specimens machined from A 508 class 3 forging material

\begin{tabular}{|c|c|c|c|c|}
\hline Specimen & $\begin{array}{c}\text { Adjusted } \\
\text { test } \\
\text { temperature } \\
\left({ }^{\circ} \mathrm{C}\right)\end{array}$ & $\begin{array}{c}T_{\text {adj }}-R T_{\text {NDT }} \\
\text { (C) }\end{array}$ & $\begin{array}{c}\text { Crack-arrest } \\
\text { toughness, } \\
\mathrm{Ka} \\
(\mathrm{MPa} / \mathrm{m})\end{array}$ & $\begin{array}{c}\text { ASTM 1221-88 } \\
\text { validity } \\
\text { criteria } \\
\text { not met" }\end{array}$ \\
\hline \multicolumn{5}{|c|}{ 12.5-mm-thick specimens } \\
\hline $\begin{array}{l}\text { BK7 } \\
\text { BK8 } \\
\text { BK9 } \\
\text { BK10 } \\
\text { BK11 } \\
\text { BK12 }\end{array}$ & $\begin{array}{l}16.9 \\
10.9 \\
26.9 \\
42.1 \\
36.2 \\
22.9\end{array}$ & $\begin{array}{l}18.4 \\
12.4 \\
28.4 \\
43.6 \\
37.7 \\
24.4\end{array}$ & $\begin{array}{r}107.7 \\
103.2 \\
102.5 \\
116.9 \\
90.4 \\
85.6\end{array}$ & $\begin{array}{c}c \\
c \\
c \\
b, c \\
c \\
c\end{array}$ \\
\hline \multicolumn{5}{|c|}{ 25-mm-thick specimens } \\
\hline $\begin{array}{l}\text { BK13 retest } \\
\text { BK16 pop-in } \\
\text { BK16 final } \\
\text { BK18 }\end{array}$ & $\begin{array}{l}22.6 \\
47.9 \\
-3.8 \\
43.2\end{array}$ & $\begin{array}{l}24.1 \\
49.4 \\
-2.3 \\
44.7\end{array}$ & $\begin{array}{r}137.8 \\
124.4 \\
77.8 \\
134.8\end{array}$ & $\begin{array}{l}b, c \\
c \\
a \\
c\end{array}$ \\
\hline
\end{tabular}

The irradiated specimen crack-arrest toughness values plotted as a function of the adjusted test temperature, together with the lower-bound, mean curve, and the ASME $K_{12}$ curves are shown in Figure 10. The ASME $K_{k}$ curve $R_{\text {NDT }}$ has been adjusted by adding to the unirradiated specimen value of $R T_{N D T}$ the amount of the CVN 41-J temperature shift $\left(\Delta \mathrm{TT}_{411}\right)$ due to neutron irradiation. A lower-bound curve is also included that was derived in the same way as that for the unirradiated specimen curve [see the explanation just before Equation (25)]. It may be seen that the specimen crack-arrest toughness values are now in a reasonable relationship to the ASME $K_{12}$ curve than that shown for the unadjusted test temperatures in Figure 8.

The crack-arrest toughness values of the unirradiated and irradiated specimens, as well as the mean and ASME $K_{12}$ curves, are given in Figure 11, and show the small shift due to neutron irradiation. The mean, lower-bound, and ASME $K_{1 \mathrm{a}}$ curves for the unirradiated and irradiated specimen crack-arrest toughness have been plotted in Figure 12 to show the relationships between the various unirradiated and irradiated specimen curves. The experimental data have been omitted from Figure 12 for purposes of clarity, since they were given in detail in previous figures. A summary of the various $T_{0}$ and $R T_{\text {NDT }}$ values for the unirradiated and irradiated specimen crack-arrest toughness results is given in Table 12. The shift between the unirradiated and irradiated specimen ASME $K_{1 \mathrm{a}}$ curves corresponds to that of the $\triangle \mathrm{TT}_{41 \mathrm{~s}}$ due to neutron irradiation. It may be seen that the shifts of the lower-bound and mean curves due to neutron irradiation are about the same as the $\Delta T_{4}{ }_{41 \mathrm{~J}}$. This agrees with the results obtained from the HSSI Sixth Irradiation Series. ${ }^{9,10}$ A different perspective on the shifts may also be obtained by plotting the unirradiated and irradiated specimen crack-arrest toughness values as a function of $\left(T-R T_{\text {NDT }}\right)$; see Figure 13. The unirradiated and irradiated specimen crack-arrest toughness values seem to form similar sets of data; thus, the CVN $\triangle T_{41}$ shift seems to agree with the experimental crack-arrest toughness data. It is not possible to draw final conclusion about potential shape changes of the crack-arrest toughness curve from the small amount of data available for the irradiated ANPA material. 


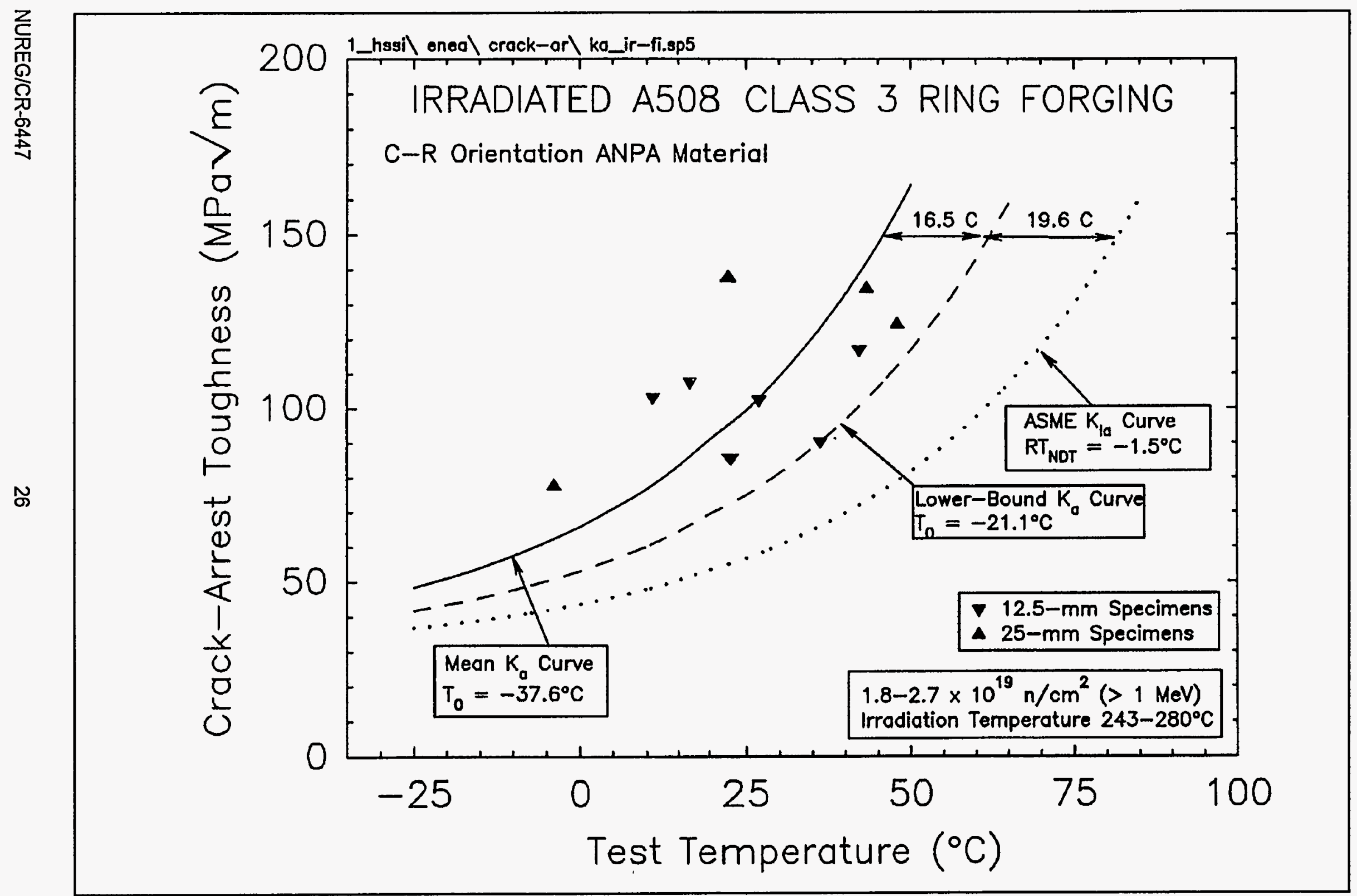

Figure 10. Crack-arrest toughness values $\left(K_{a}\right)$ of irradiated $A 508$ class 3 forging material with an $R T_{\text {Nor }}=-1.5^{\circ} \mathrm{C}$, plotted as a function of the adjusted test temperature, together with the lower-bound and the ASME $K_{1 a}$ curves. 


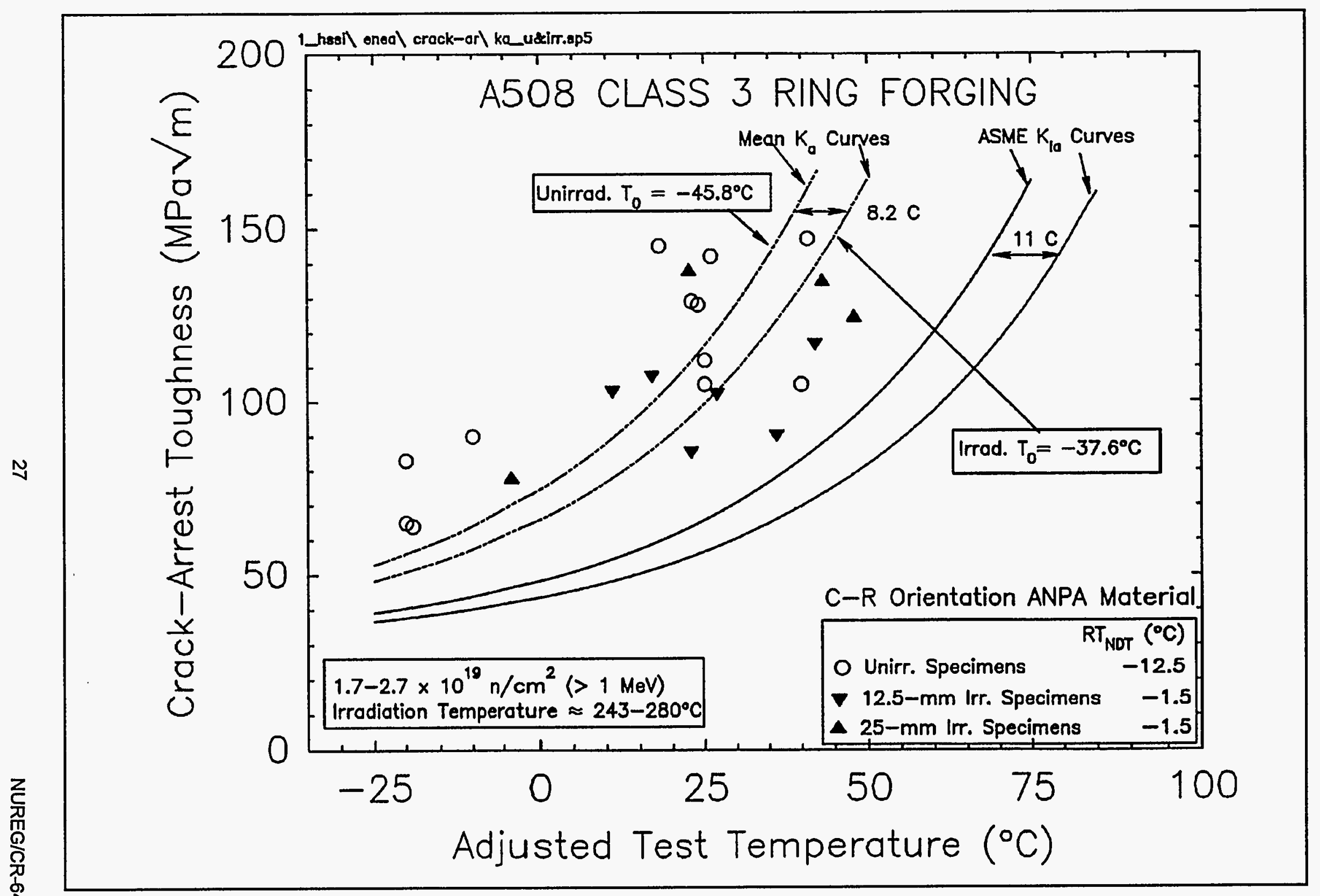

Figure 11. Toughness of unirradiated and irradiated crack-arrest specimens from the ANPA A 508 class 3 forging material. 


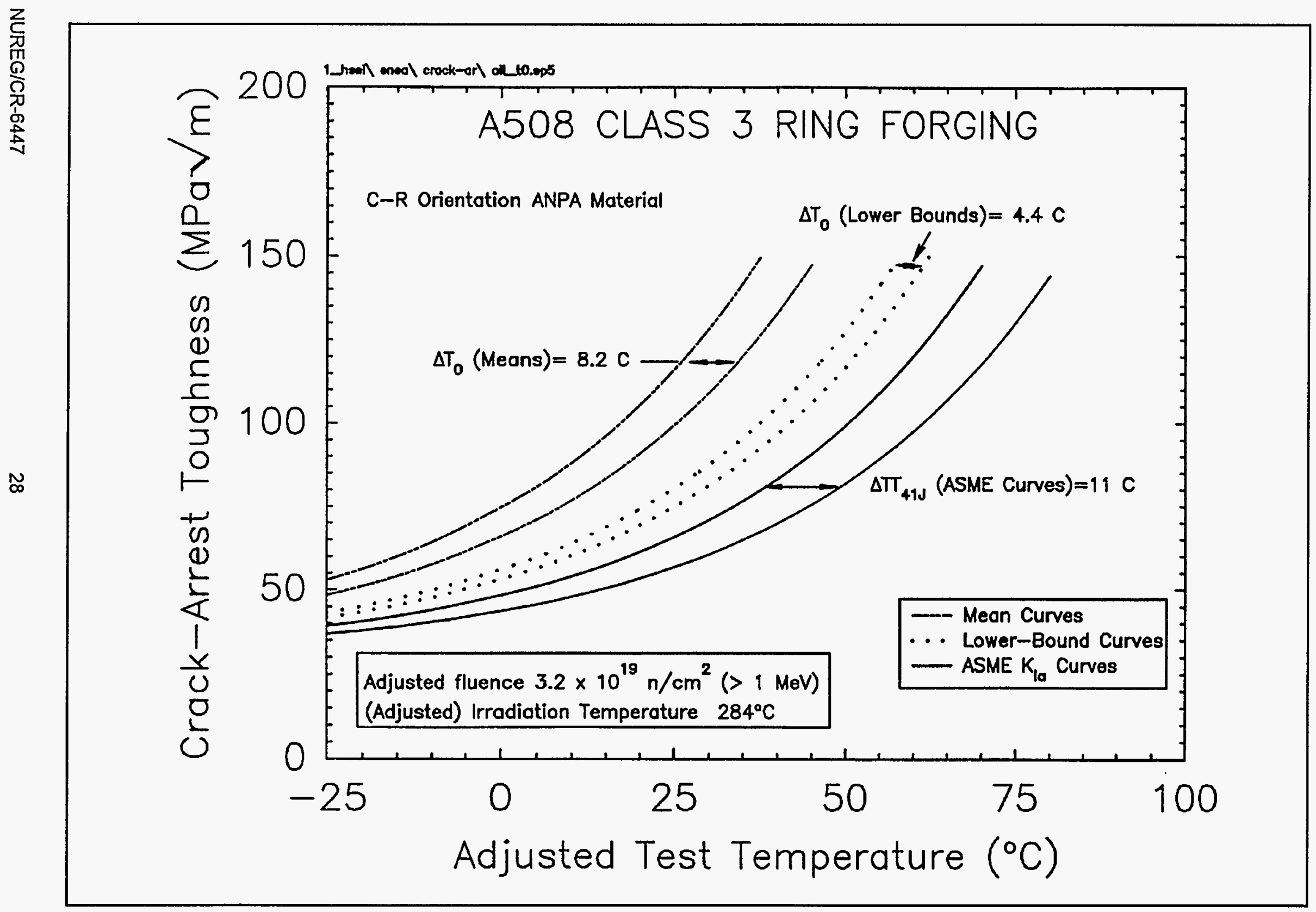

Figure 12. Unirradiated and irradiated crack-arrest toughness lower-bound, mean, and ASME $K_{\mathrm{la}}$ curves for the ANPA A 508 class 3 forging material. 
Table 12. Mean and lower-bound $T_{0}$ and $R T_{\text {NDT }}$ values derived from unirradiated and irradiated crack-arrest toughness results of ANPA A 508 class 3 forging material (shift of 41-J Charpy V-notch impact energy level was $11 \mathrm{C}$ )

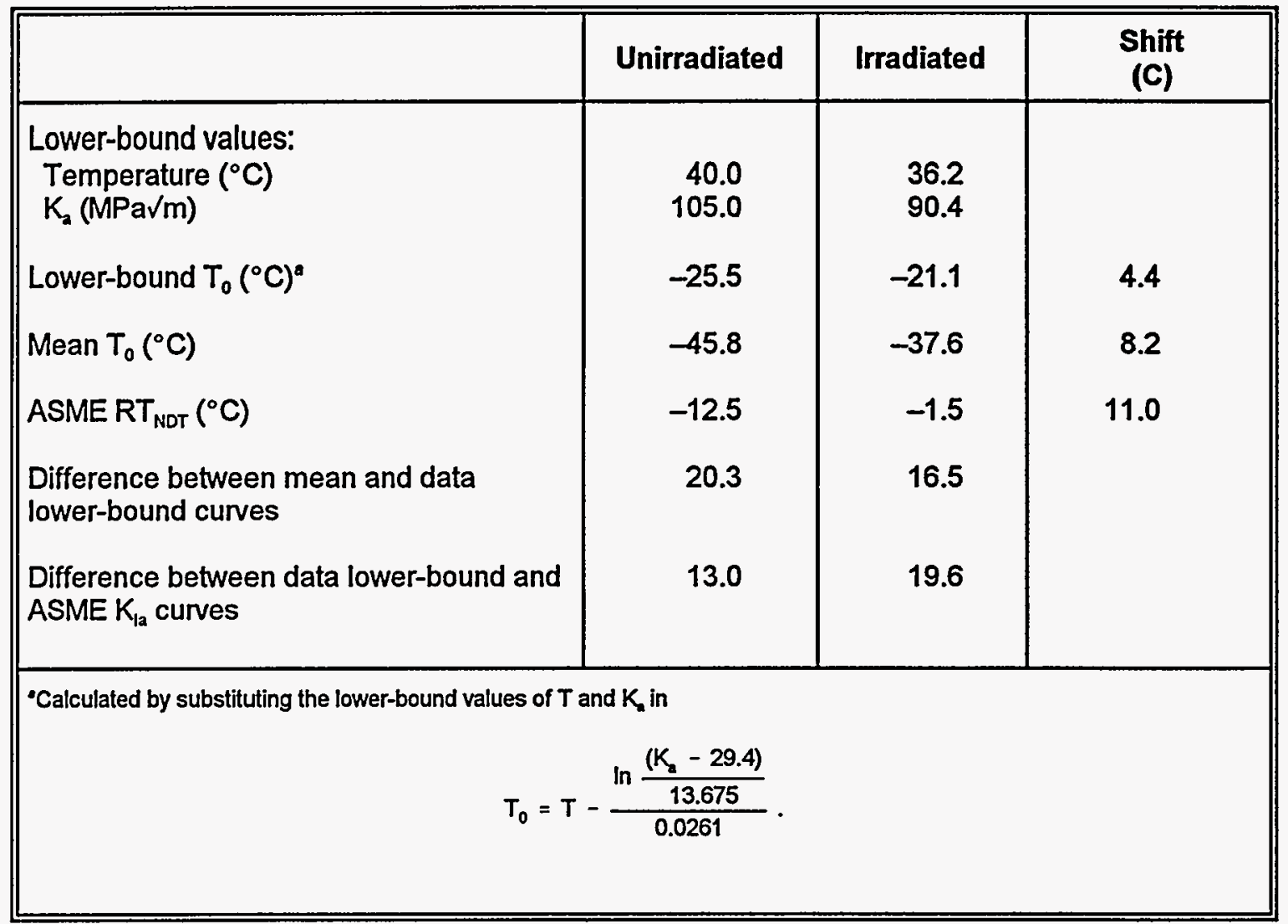




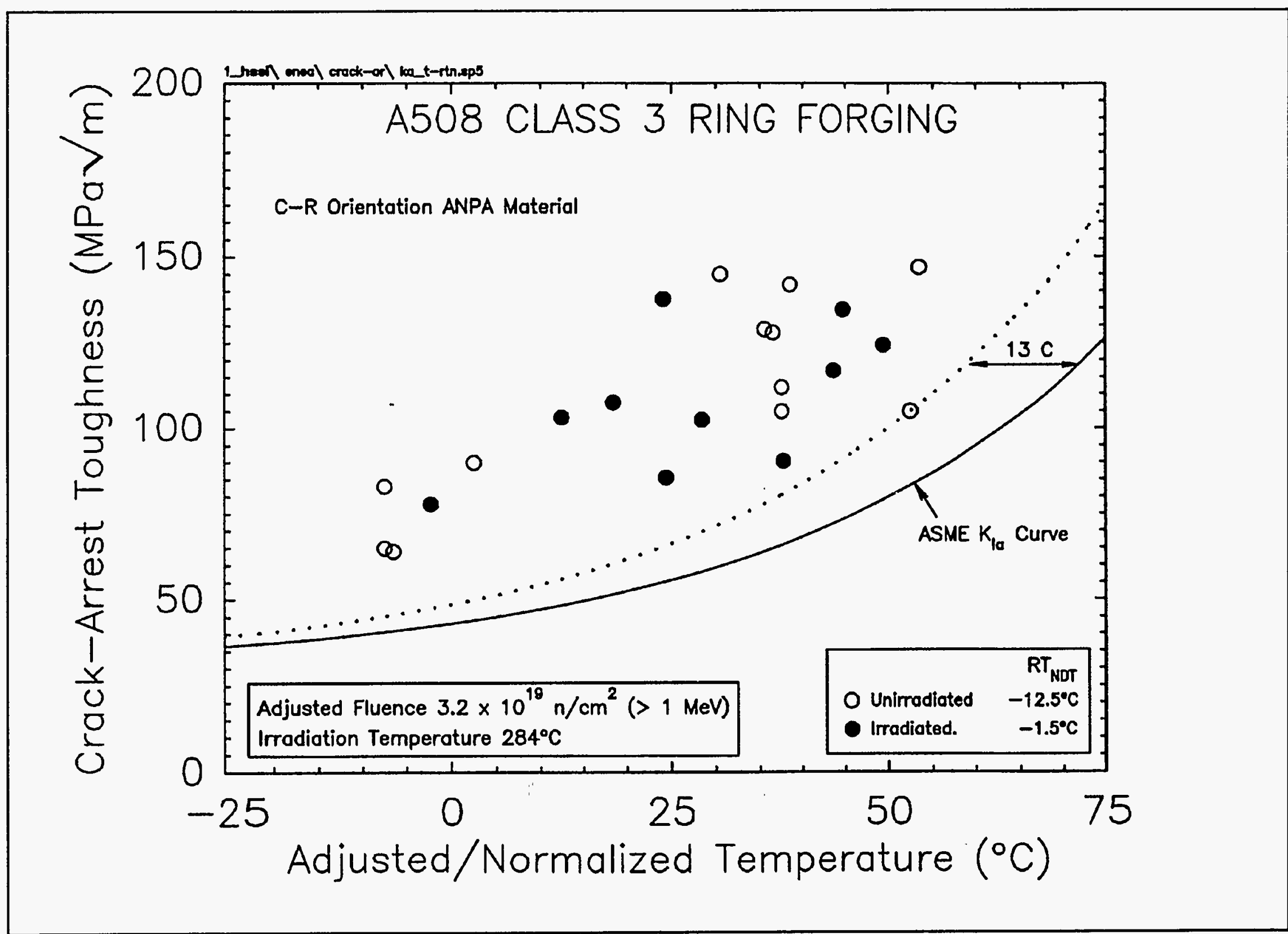

Figure 13. Toughness of unirradiated and irradiated crack-arrest specimens from the ANPA A 508 class 3 forging material, plotted as a function of $\left(T-R T_{N D T}\right)$. 


\section{Summary and Conclusions}

A special fixture was designed, fabricated, and used successfully for testing nine irradiated crack-arrest specimens fabricated from A 508 class 3 forging material irradiated at 243 to $280^{\circ} \mathrm{C}$ to a fluence of 1.7 to $2.7 \times 10^{19}$

neutrons $/ \mathrm{cm}^{2}(>1 \mathrm{MeV})$. Special mounting blocks to receive the ORNL clip gage were designed, and the greaterthan-standard CMODs were accounted for. The test temperatures were adjusted to account for the variations in irradiation temperature and fluence in the crack-arrest specimens with respect to the toughness reference values that correspond to those of CVN specimens irradiated at $284^{\circ} \mathrm{C}$ to a fluence of $3.2 \times 10^{19}$ neutrons $/ \mathrm{cm}^{2}(>1 \mathrm{MeV})$ in the same capsule as the crack-arrest specimens. This adjustment resulted in a shift to lower effective test temperatures of all the data and, in particular, moved two data points that appeared to lie close to or below the ASME $K_{12}$ curve to positions that seemed more reasonable with respect to the remaining data. The shifts of the lower-bound and mean curves due to neutron irradiation are approximately the same as the CVN 41-J temperature shift. It is significant to note that the small (averaging approximately $10^{\circ} \mathrm{C}$ ) shifts in the mean and lower-bound crack-arrest toughness curves confirm that a low copper content in A 508 class 3 forging material can be expected to result in small shifts of the transition toughness curve.

\section{References}

1. R. K. Nanstad and R. G. Berggren, Martin Marietta Energy Systems, Inc., Oak Ridge Natl. Lab., Oak Ridge, Tennessee, Irradiation Effects on Charpy Impact and Tensile Properties of Low Upper-Shelf Welds, HSSI Series 2 and 3, USNRC Report NUREG/CR-5696 (ORNLTM-11804), August 1991.

2. Title 10, Code of Federal Regulations, Part 50, U.S. Government Printing Office, Washington, D.C. (revised annually). ${ }^{\dagger}$

3. S. T. Rolfe and J. M. Barsom, Fracture and Fatigue Control in Structures, Applications of Fracture Mechanics, p. 180, Prentice-Hall, New Jersey, $1977 .^{\dagger}$

4. R. K. Nanstad, F. M. Haggag, D. E. McCabe, S. K. Iskander, K. O. Bowman, and B. H. Menke, Martin Marietta Energy Systems, Inc., Oak Ridge Natl. Lab., Oak Ridge, Tennessee, Irradiation Effects on Fracture Toughriass of Two High-Copper Submerged-Arc Welds, HSSI Series 5, USNRC Report NUREG/CR-5913, Vol. 1

(ORNLTM-12156N1), October 1992.

5. C. W. Marschall and A. R. Rosenfield, "Crack-Arrest Tests of Irradiated High-Copper ASTM A508 SubmergedArc Weld Metal," pp. 2467-2475 in Advances in Fracture Research, Vol. 5, Proceedings of the 5th International Conference on Fracture (ICF5), D. A. Francosi et al., Eds., Pergamon Press, Oxford, England, April 1981. ${ }^{\dagger}$

6. T. R. Mager and C. W. Marschall, Development of a Crack-Arrest Toughness Data Bank for Irradiated Reactor Pressure Vessel Materials, EPRI NP-3616, Electric Power Research Institute, Palo Alto, California, July 1984. ${ }^{\dagger}$

7. C. W. Marschall, A. R. Rosenfield, M. P. Landow, T. R. Mager, R. G. Lott, and S. W. Tagart, Jr., "Crack-Arrest Behavior of Pressure Vessel Plates and Weldments as Influenced by Radiation and Copper Content," pp. 1059-1083 in Effects of Radiation on Materials: Twelfth International Symposium, ASTM STP 870, F. A. Garner and J. S. Perrin, Eds., American Society for Testing and Materials, Philadelphia, 1985. ${ }^{\dagger}$

8. J. J. McGowan, R. K. Nanstad, and K. R. Thoms, Martin Marietta Energy Systems, Inc., Oak Ridge Natl. Lab., Oak Ridge, Tennessee, Characterization of Irradiated Current-Practice Welds and A 533 Grade B Class 1 Plate for Nuclear Pressure Vessel Service, USNRC Report NUREG/CR-4880, Vol. 1 (ORNL/TM-6484N1), July 1988."

9. S. K. Iskander, W. R. Corwin, and R. K. Nanstad, Martin Marietta Energy Systems, Inc., Oak Ridge Natl. Lab., Oak Ridge, Tennessee, Results of Crack-Arrest Tests on Two Irradiated High-Copper Welds, USNRC Report NUREG/CR-5584 (ORNL/TM-11575), December 1990. 
10. S. K. Iskander, W. R. Corwin, and R. K. Nanstad, Martin Marietta Energy Systems, Inc., Oak Ridge Natl. Lab., Oak Ridge, Tennessee, Crack-Arrest Tests on Two Irradiated High-Copper Welds. Phase Il: Results of Duplex-Type Specimens, USNRC Report NUREG/CR-6139 (ORNL/TM-12513), March 1994."

11. F. M. Haggag, W. R. Corwin, and R. K. Nanstad, Martin Marietta Energy Systems, Inc., Oak Ridge Natl. Lab., Oak Ridge, Tennessee, Irradiation Effects on Strength and Toughness of Three-Wire Series-Arc Stainless Steel Weld Overlay Cladding, USNRC Report NUREG/CR-5511 (ORNL/TM-11439), February 1990."

12. P. P. Milella, A. Pini, and C. W. Marschall, "Radiation Effects on the Mechanical Properties of SA 508 Cl. 3 Forging," pp. 227-237 in Radiation Embrittlement of Nuclear Pressure Vessel Steels: An International Review (Fourth Volume), ASTM STP 1170, L. E. Steele, Ed., American Society for Testing and Materials, Philadelphia, 1993. ${ }^{\dagger}$

13. P. P. Milella, A. Pini, S. K. Iskander, C. W. Marschall, and A. R. Rosenfield, "Effects of Radiation on CrackInitiation and Crack-Arrest Toughness for SA508 Cl. 3 Steel," pp. 237-245 in Fatigue and Fracture Mechanics in Pressure Vessels and Piping, PVP-Vol. 304, H. S. Mehta et al., Eds., American Society of Mechanical Engineers, New York, 1995. ${ }^{\dagger}$

14. W. L. Server, J. W. Sheckherd, and R. A. Wullaert, Fracture Toughness Data for Ferritic Nuclear Pressure Vessel Materials, EPRI NP-119, Electric Power Research Institute, Palo Alto, California, April $1976 .^{\dagger}$

15. C. W. Marschall, P. N. Mincer, and A. R. Rosenfield, "Subsize Specimens for Crack-Arrest Testing, pp. II-295-HI-319 in Fracture Mechanics: Fourteenth Symposium - Volume II, ASTM STP 791, J. C. Lewis and G. Sines, Eds., American Society for Testing and Materials, Philadelphia, 1983. ${ }^{\dagger}$

16. D. E. McCabe, R. K. Nanstad, S. K. Iskander, and R. L. Swain, Martin Marietta Energy Systems, Inc., Oak Ridge Natl. Lab., Oak Ridge, Tennessee, Unirradiated Material Properties of Midland Weld WF-70, USNRC Report NUREG/CR-6249 (ORNL/TM-12777), October 1994:"

17. W. L. Fourney, Union Carbide Corp., Nucl. Div., Oak Ridge Natl. Lab., Oak Ridge, Tennessee, "Investigation of Damping and of Cleavage-Fibrous Transition in Reactor-Grade Steel," pp. 21-46 in Heavy-Section Steel Technology Program Quarterly Progress Report for October-December 1981, NUREG/CR-2141, Vol. 4 (ORNLTM-8251), April 1982."

18. A. R. Rosenfield, P. N. Mincer, and C. W. Marschall, "High-Temperature Crack-Arrest Testing Using Compact Specimens," pp. 73-85 in Fracture Mechanics: Eighteenth Symposium, ASTM STP 945, D. T. Read and R. P. Reed, Eds., American Society for Testing and Materials, Philadelphia, $1988 .^{\dagger}$

19. P. P. Milella, A. Pini, and M. Bara Caracciolo, "Assessment of Crack-Arrest Properties of Nuclear Pressure Vessel Steels by Means of Small Specimens," pp. 125-130 in Transactions of the 10th International Conference on Structural Mechanics in Reactor Technology, Vol. G, A. S. Hadjian, Ed., American Association for Structural Mechanics in Reactor Technology, Los Angeles, 1989..$^{\dagger}$

20. J. C. Newman, Jr., Crack-Opening Displacements in Center-Crack, Compact, and Crack-Line Wedge-Loaded Specimens, NASA TN D-8268, NASA Langley Research Center, Hampton, Virginia, July $1976 .^{\dagger}$

21. R. H. Bryan et al., Martin Marietta Energy Systems, Inc., Oak Ridge Natl. Lab., Oak Ridge, Tennessee, Pressurized-Thermal-Shock Test of 6-in.-Thick Pressure Vessels. PTSE-2: Investigation of Low Tearing Resistance and Warm Prestressing, USNRC Report NUREG/CR-4888 (ORNL-6377), December 1987."

22. D. E. McCabe, R. K. Nanstad, S. K. Iskander, and R. L. Swain, Martin Marietta Energy Systems, Inc., Oak Ridge Natl. Lab., Oak Ridge, Tennessee, Unirradiated Material Properties of Midland Weld WF-70, USNRC Report NUREG/CR-6249 (ORNLTM-2777), October 1994. 
23. D. B. Barker, R. Chona, W. R. Corwin, W. L. Fourney, G. R. Irwin, C. W. Marschall, A. R. Rosenfield, and E. T. Wessel, "A Method for Determining the Crack-Arrest Toughness of Ferritic Materials," pp. 569-593 in Fracture Mechanics: Nineteenth Symposium, ASTM STP 969, T. A. Cruse, Ed., American Society for Testing and Materials, Philadelphia, 1988. ${ }^{\dagger}$

24. G. R. Odette and G. E. Lucas, "Irradiation Embrittlement of Reactor Pressure Vessel Steels: Mechanisms, Models, and Data Correlations," pp. 206-241 in Radiation Embrittlement of Nuclear Pressure Vessel Steels: An International Review (Second Volume), ASTM STP 909, L. E. Steele, Ed., American Society for Testing and Materials, Philadelphia, 1986. ${ }^{\dagger}$

Avallable for purchase from National Technical Information Service, Springfield, VA 22161.

tAvailable in public technical libraries. 
Appendix A

Results of Temperature Survey 


\section{Appendix A \\ Results of Temperature Survey}

This appendix contains the detailed results of the temperature survey conducted to ensure that the reading of the removable thermocouple (TC) reflects that of the specimen. The TCs were tack-welded at various locations, designated 1, 2, 3, etc. The TC locations are shown in Figure A-1. The temperature conditioning medium is liquid nitrogen vapor for temperatures below room temperature (RT). At higher than RT, the specimen was heated by both electrically heated cartridges embedded in the fixture and heater elements below and above the specimen. The general procedure was to (1) turn on the heating or cooling medium, (2) take the reading of the removable TC labeled "Probe" in Tables A-1 through A-8, (3) record the various TC readings, and (4) re-record the probe temperature. If the probe temperature had changed significantly from the first reading, then the conditioning medium was turned on again. The time at which the conditoning was started was also recorded as a guide to the time required for the specimen to achieve the recorded temperature distribution.

In general, if the probe temperature remained steady, within 1 or $2^{\circ}$, for about $2 \mathrm{~min}$, this was a good indication that a steady state of temperature was achieved in the specimen. Each of the tables in this appendix gives the results of a temperature distribution in a specimen for a particular nominal temperature and for specimens in both the socalled "normal" and "inverted" positions. 


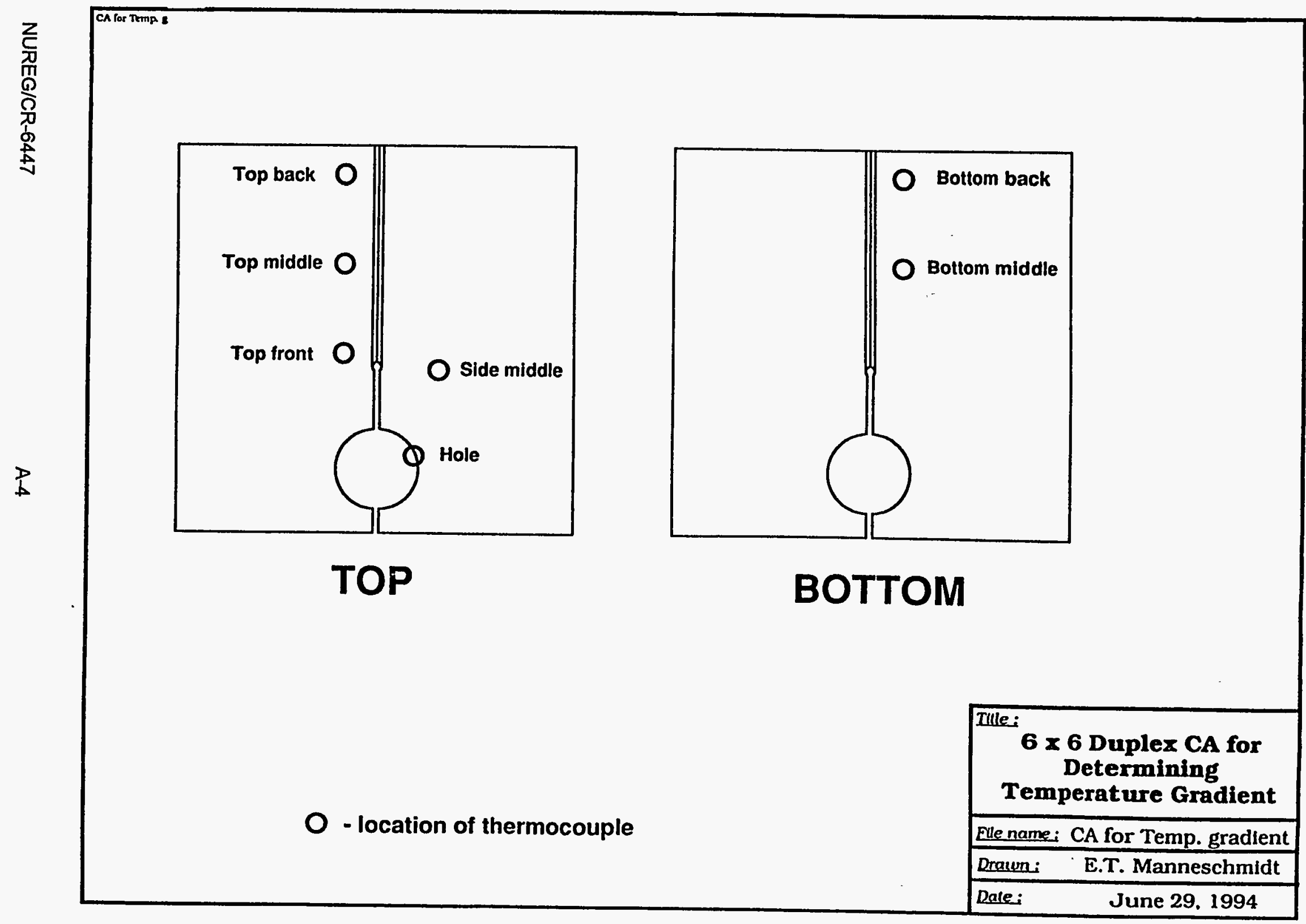

Figure A-1. A $6 \times 6$ duplex CA for determining temperature gradient. 
Table A-1.

CA Fix. N Eval $-50 \%$ wedge

\title{
Crack Arrest Fixture Temperature Gradient
}

\section{Thermocouple locations}

$1=$ Top Front

\author{
$2=$ Top Middle $3=$ Top Rear
}

$4=$ Bottom front

(TEMP PROB RESEATED)

5=Bottom middle $6=$ Bottom back $7=S$ Side middle $8=$ Diff. between last probe temp vs probe with wh.

Target Temp. $-50^{\circ} \mathrm{C} /-58^{\circ} \mathrm{F}$

\begin{tabular}{|c|c|c|c|c|c|c|c|c|c|c|c|}
\hline \multirow{3}{*}{$\begin{array}{c}\text { OA Temp } \\
\& W 1 \\
\end{array}$} & \multirow{3}{*}{$\begin{array}{l}\text { Probe } \\
\text { Temp }\end{array}$} & \multirow{2}{*}{\multicolumn{8}{|c|}{ Thermocouples ${ }^{\circ} \mathrm{F}$}} & \multirow[b]{3}{*}{ Time } & \multirow{3}{*}{$\begin{array}{l}\text { Probe } \\
\text { Temp }\end{array}$} \\
\hline & & & & & & & & & & & \\
\hline & & 1 & 2 & 3 & 4 & 5 & 6 & 7 & 8 & & \\
\hline-80 & -47.6 & -25 & -31 & -34 & -23 & -31 & -35 & -21.8 & NA & 37 & -41.8 \\
\hline-100 & -62.0 & -41 & -46 & -50 & -39 & -47 & -50 & -38.9 & 2.3 & 41 & -60.2 \\
\hline-100 & -65.4 & -47 & -51 & -55 & -45 & .52 & -55 & -45.3 & 1.7 & 44 & -62.2 \\
\hline-90 & -64.0 & -51 & -55 & -58 & -49 & -56 & -59 & -49.8 & 1.2 & 47 & -62.2 \\
\hline-70 & -63.7 & -53 & -57 & -60 & -51 & -58 & -60 & .52 .8 & 0.7 & 49 & -62.2 \\
\hline-65 & -63.0 & -55 & -58 & -60 & -52 & -59 & -61 & -54.6 & $\begin{array}{|ll|}4 & R \\
\end{array}$ & 51 & -62.8 \\
\hline-65 & -63.6 & -56 & -59 & -60 & -54 & -60 & -61 & -55.8 & 0.3 & 35 & -62.9 \\
\hline-65 & -63.5 & -56 & -59 & -60 & -54 & -60 & -62 & -56.9 & $.2 R$ & 55 & -63.3 \\
\hline-65 & -63.8 & -57 & -59 & -61 & -55 & -60 & -62 & -57.9 & - & 57 & -61.4 \\
\hline W1 & -61.9 & -56 & -58 & -59 & -54 & -60 & -60 & -57.4 & - & 58 & -63.1 \\
\hline-65 & -63.9 & -57 & -59 & -60 & -55 & -60 & -61 & -58.4 & - & 60 & -61.1 \\
\hline$W_{1}$ & -61.7 & -56 & -58 & -59 & -54 & 59 & -60 & -57.8 & -0.2 & 62 & -60.6 \\
\hline-62 & -61.1 & -56 & -57 & -58 & -53 & -59 & -59 & -57.4 & -0.1 & 63 & -60.5 \\
\hline-62 & -61.0 & -55 & -57 & -58 & -53 & -58 & -59 & -57.2 & -0.1 & 65 & -60.4 \\
\hline-62 & -61.0 & -55 & -57 & -58 & -53 & -58 & -59 & -56.9 & - & 67 & -62.9 \\
\hline-65 & -63.0 & -57 & -58 & -59 & -54 & -59 & -60 & -58.2 & $\mathrm{R}$ & 69 & -63.3 \\
\hline-65 & -63.9 & -57 & -59 & -60 & -55 & -60 & -60 & -58.9 & - & 71 & -63.3 \\
\hline-65 & -63.8 & -57 & -59 & -60 & -55 & -60 & -61 & -59.3 & $\mathrm{R}$ & 73 & -63.4 \\
\hline-65 & -64.0 & -58 & -59 & -60 & -55 & -60 & -61 & -59.7 & - & 75 & -61.3 \\
\hline-63 & -61.8 & -57 & -58 & -58 & -54 & 59 & -59 & -58.9 & -0.1 & 77 & -61.7 \\
\hline-63 & -62.1 & -56 & -58 & -58 & -54 & -59 & -59 & -58.8 & -0.1 & 79 & -61.1 \\
\hline-63 & -61.5 & -56 & -57 & -58 & -53 & -58 & -59 & -58.4 & $R$ & 81 & -61.0 \\
\hline-63 & -60.6 & -56 & -57 & -58 & -53 & -58 & -59 & -58.2 & NA & 83 & -60.6 \\
\hline-63 & -62.1 & -56 & -57 & -58 & -53 & -58 & -59 & -58.2 & NA & 84 & 60.6 \\
\hline
\end{tabular}

Comments: OA Temp \& W1 -

SPECIMEN IN NORMAL POSITION

$O A=O f f A t$, the temperature the $L N$ was turned off. Each time the nitrogen was turned off, temperature readings were not taken until 1 minute had elapsed.

W $1=$ Wait 1 minute before recording temperatures. After the first temps. were recorded and before the nitrogen was turned back on another recording was made 60 seconds after the first.

Test wedge WAS In the specimen during temperature evaluations.

Readings were taken from left to right starting and finishing with the "control" thermocouple. 
Table A-2.

CA Fix. N Eval $50^{\circ} /$ wedge

\section{Crack Arrest Fixture Temperature Gradient}

Test Wedge Inserted

$1=$ Top Frent

5=Bottom middle
Thermocouple locations

$\begin{array}{ll}2=\text { Top Middle } & 3=\text { Top Rear } \\ 6=\text { Bottom back } & \text { ZESide middle }\end{array}$

(TEMP PROB RESEATED)

$4=$ Bottom front

$8=$ Hole

Target Temp. $50^{\circ} \mathrm{C} / 122^{\circ} \mathrm{F}$

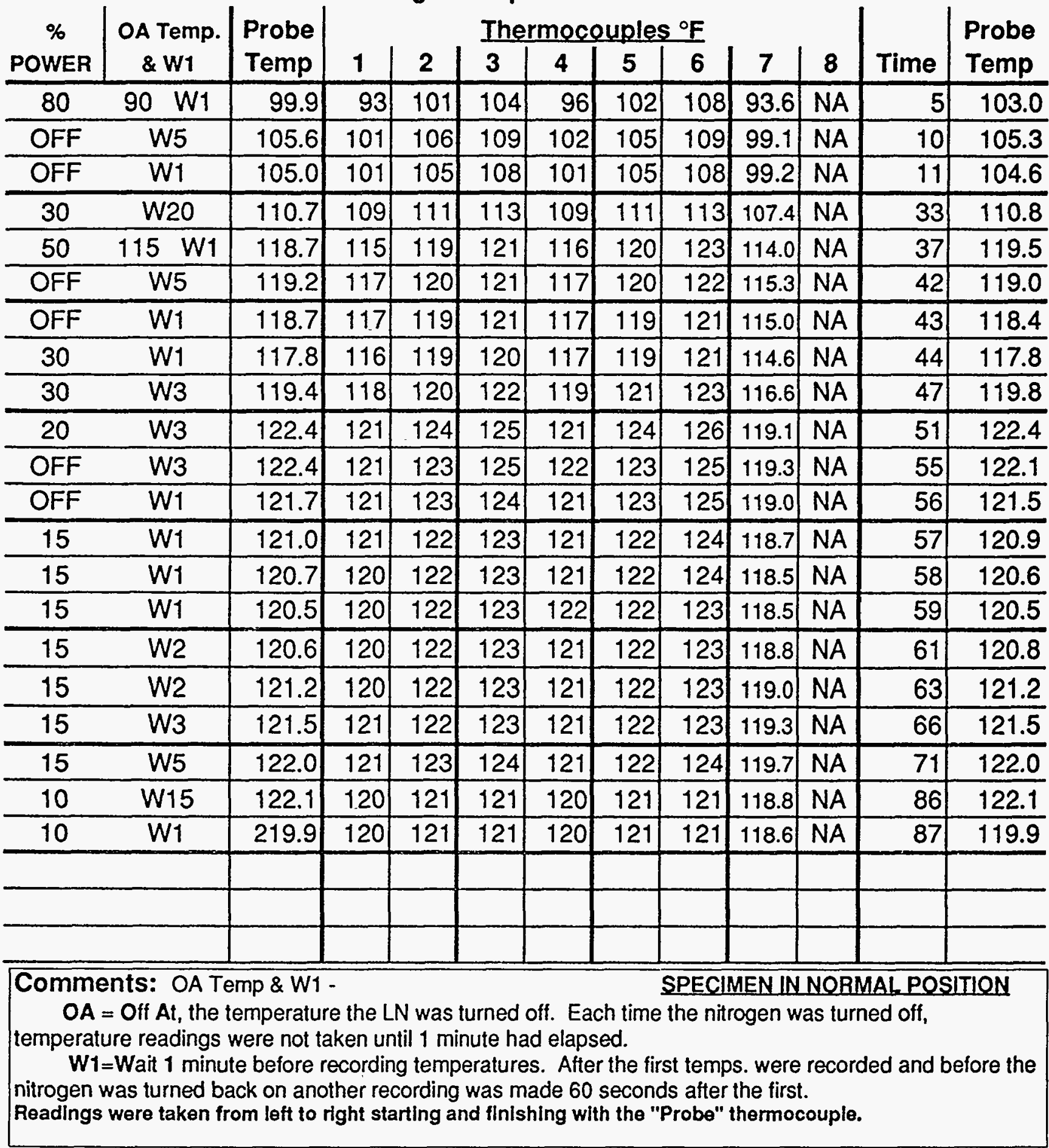


Table A-3.

CA Fix. N Eval $100 \%$ wedge

\section{Crack Arrest Fixture Temperature Gradient}

Test Wedge Inserted

$1=$ Ter Front

$5=$ Bottom middle
Thermocouple locations

$2=$ Top Middle

$6=$ Bottom back
$3=$ Ton Bear

$Z$ =Side middle
(TEMP PROB RESEATED)

$4=$ Bottem front

$8=$ See note below

Target Temp. $100^{\circ} \mathrm{C} / 212^{\circ} \mathrm{F}$

\begin{tabular}{|c|c|c|c|c|c|c|c|c|c|c|c|c|}
\hline \multirow{3}{*}{$\begin{array}{c}\% \\
\text { POWER } \\
100 \% \\
\end{array}$} & \multirow{2}{*}{$\begin{array}{c}\text { OA Temp. } \\
\& W 1\end{array}$} & \multirow{2}{*}{$\begin{array}{l}\text { Probe } \\
\text { Temp }\end{array}$} & \multicolumn{8}{|c|}{ Thermocouples ${ }^{\circ} \mathrm{F}$} & \multirow[b]{2}{*}{ Time } & \multirow{2}{*}{$\begin{array}{l}\text { Probe } \\
\text { Temp } \\
\end{array}$} \\
\hline & & & 1 & 2 & 31 & 4 & 5 & 6 & 7 & 8 & & \\
\hline & $240^{\circ}$ & & & & & & & & & & & \\
\hline LN & $212 \quad W 2$ & 210.3 & 207 & 213 & 215 & 208 & 212 & 215 & 206.7 & & 44 & 210.0 \\
\hline \multicolumn{2}{|r|}{ W1 } & 209.5 & 206 & 212 & 214 & 208 & 211 & 214 & 206.0 & & 45 & 209.1 \\
\hline \multirow[t]{2}{*}{20} & W1 & 207.8 & 205 & 210 & 212 & 206 & 208 & 212 & 204.7 & & 47 & 207.4 \\
\hline & W2 & 205.7 & 204 & 208 & 210 & 205 & 207 & 210 & 203.2 & 0.3 & 49 & 205.5 \\
\hline \multirow[t]{3}{*}{30} & W1 & 204.8 & 202 & 207 & 209 & 205 & 206 & 208 & 202.2 & $\mathrm{R}$ & 50 & 204.7 \\
\hline & W2 & 204.3 & 202 & 206 & 208 & 203 & 205 & 208 & 201.5 & 0.2 & 52 & 204.3 \\
\hline & W2 & 204.4 & 202 & 206 & 208 & 203 & 205 & 208 & 201.4 & & 54 & 204.5 \\
\hline 50 & W2 & 207.1 & 203 & 207 & 211 & 204 & 207 & 210 & 202.8 & & 57 & 207.7 \\
\hline \multirow[t]{6}{*}{25} & W3 & 210.4 & 206 & 211 & 213 & 207 & 210 & 213 & 205.3 & -0.1 & 60 & 210.6 \\
\hline & W2 & 211.0 & 207 & 211 & 214 & 208 & 211 & 214 & 206.1 & 0 & 62 & 211.0 \\
\hline & W2 & 211.1 & 207 & 212 & 214 & 208 & 211 & 214 & 206.7 & 0 & 64 & 211.1 \\
\hline & W2 & 211.0 & 207 & 212 & 214 & 209 & 211 & 214 & 206.9 & 0 & 66 & 211.0 \\
\hline & W2 & 210.9 & 208 & 212 & 214 & 209 & 211 & 214 & 207.1 & 0.1 & 68 & 210.9 \\
\hline & W20 & 210.2 & 208 & 211 & 213 & 209 & 211 & 213 & 207.5 & 0.1 & 88 & 210.3 \\
\hline & & & & & & & & & & & & \\
\hline
\end{tabular}

Thermocouple \#8 shows the change in temp. reading when weight is applied to the probe thermocouple. " $R$ " indicates that the probe was reseated.

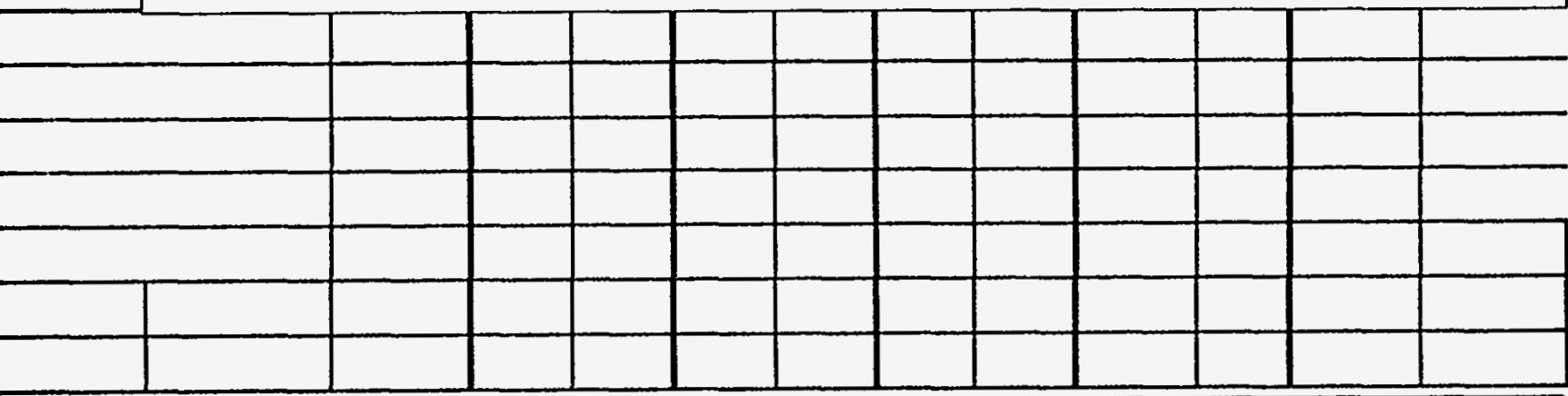

Comments:

$O A=$ Power Off At temperature.

Readings were taken from left to right starting and finlshing with the "control" thermocouple.

SPECIMEN IN NORMAL POSITION

$W 1=W a i t 1$ minute before recording temperatures. 
Table A-4.

CA Fix. $N$ Eval $0 \%$ wedge

Crack Arrest Fixture Temperature Gradient

Room Temp.

Thermocouple locations

$1=$ Top Front

$2=$ Top Middle

$3=$ Toen Rear

(TEMP PROB RESEATED)

5=Bottom middle

$6=$ Bottom back

$Z=$ Side middle

$4=$ Bettom front

Target Temp. $0^{\circ} \mathrm{C} / 32^{\circ} \mathrm{F}$

\begin{tabular}{|c|c|c|c|c|c|c|c|c|c|c|c|}
\hline OA Temp & Probe & & & & $\mathrm{mc}$ & Jple & & & & & Probe \\
\hline \& W1 & Temp & 1 & 2 & 3 & 4 & 5 & 6 & 7 & 8 & Time & Temp \\
\hline $32 W 1$ & 35.1 & 44 & 40 & 36 & 44 & 40 & 36 & $47 . ?$ & NA & 1 & 35.8 \\
\hline $32 W 1$ & 33.8 & 41 & 38 & 35 & 41 & 38 & 35 & 43.2 & NA & 3 & 34.3 \\
\hline $30 W 1$ & 31.5 & 38 & 35 & 33 & 38 & 35 & 33 & 39.7 & NA & 5 & 32.0 \\
\hline $30 \mathrm{W1}$ & 31.5 & 36 & 34 & 32 & 37 & 34 & 32 & 38.0 & NA & 7 & 31.5 \\
\hline W1 & 32.4 & 37 & 35 & 33 & 38 & 34 & 33 & 37.9 & NA & 8 & 32.7 \\
\hline $30 W 1$ & 32.9 & 35 & 34 & 32 & 37 & 33 & 32 & 36.4 & NA & 10 & 31.3 \\
\hline $30 W 1$ & 32.6 & 35 & 33 & 32 & 36 & 33 & 31 & 35.5 & NA & 12 & 31.0 \\
\hline $30 W 1$ & 32.8 & 34 & 33 & 32 & 36 & 33 & 31 & 35.2 & NA & 14 & 31.0 \\
\hline $29 W 1$ & 29.4 & 34 & 32 & 31 & 35 & 32 & 30 & 34.2 & NA & 15 & 29.7 \\
\hline $28 W 1$ & 28.4 & 33 & 31 & 30 & 34 & 31 & 29 & 33.2 & NA & 17 & 28.7 \\
\hline W1 & 29.3 & 33 & 32 & 31 & 34 & 31 & 30 & 33.2 & $N A$ & 18 & 29.5 \\
\hline $29 W_{1}$ & 29.5 & 33 & 32 & 31 & 34 & 31 & 30 & 33.1 & NA & 20 & 29.7 \\
\hline$W_{1}$ & 30.2 & 33 & 32 & 32 & 35 & 32 & 31 & 33.2 & NA & 21 & 30.4 \\
\hline 29 W1 & 29.5 & 33 & 32 & 31 & 34 & 31 & 31 & 32.8 & NA & 22 & 29.8 \\
\hline & & & & & & & & & & & \\
\hline & & & & & & & & & & & \\
\hline & & & & & & & & & & & \\
\hline & & & & & & & & & & & \\
\hline & & & & & & & & & & & \\
\hline & & & & & & & & & & & \\
\hline & & & & & & & & & & & \\
\hline & & & & & & & & & & & \\
\hline & & & & & & & & & & & \\
\hline
\end{tabular}

Comments: OA Temp \& W1 -

SPECIMEN IN NORMAL POSITION

$O A=$ Off $A t$, the temperature the $L N$ was turned off. Each time the nitrogen was turned off, temperature readings were not taken until 1 minute had elapsed.

W1 $=$ Wait 1 minute before recording temperatures. After the first temps. were recorded and before the nitrogen was turned back on another recording was made 60 seconds after the first.

Test wedge WAS inserted into the specimen during temperature evaluations.

Readings were taken from left to right starting and finlshing with the "control" thermocouple. 
Table A-5.

CA Fix. I Eval $100^{\circ}$ wedge

Crack Arrest Fixture Temperature Gradient

2/13/95

Test Wedge Inserted

$1=$ Top Front
$5=$ Bottem middle

Thermocouple locations

(TEMP PROB RESEATED)

$2=$ Top Middle

$6=$ Bottom back
$3=$ Top Rear

$\mathrm{Z}=$ Side middle
$4=$ Bettom front

$8=$ Hole

Target Temp. $100^{\circ} \mathrm{C} / 212^{\circ} \mathrm{F}$

\begin{tabular}{|c|c|c|c|c|c|c|c|c|c|c|c|c|}
\hline \multirow{2}{*}{$\begin{array}{c}\% \\
\text { POWER }\end{array}$} & \multirow{2}{*}{$\begin{array}{c}\text { OA Temp. } \\
\& W_{1}\end{array}$} & \multirow{2}{*}{$\begin{array}{l}\text { Probe } \\
\text { Temp }\end{array}$} & \multicolumn{8}{|c|}{ Thermocouples ${ }^{\circ} \mathrm{F}$} & \multirow[b]{2}{*}{ Time } & \multirow{2}{*}{$\begin{array}{l}\text { Probe } \\
\text { Temp }\end{array}$} \\
\hline & & & 1 & 2 & 3 & 4 & 5 & 6 & 7 & 8 & & \\
\hline $100-0$ & $190 \mathrm{~W} 1$ & 212.6 & 186 & 206 & 227 & 187 & 204 & NA & 180.0 & 152 & 18 & 216.6 \\
\hline \multirow{7}{*}{$\begin{array}{l}\frac{1}{1} \\
0 \\
\frac{0}{11} \\
\frac{1}{8}\end{array}$} & OFF W1 & 220.1 & 199 & 217 & 232 & 201 & 215 & NA & 193.5 & 167 & 20 & 220.1 \\
\hline & W1 & 219.7 & 203 & 218 & 230 & 204 & 216 & NA & 197.0 & 172 & 21 & 218.4 \\
\hline & W1 & 218.4 & 210 & 218 & 228 & 206 & 217 & NA & 200.1 & 178 & 22 & 217.9 \\
\hline & $W_{1}$ & 217.2 & 206 & 217 & 226 & 207 & 216 & NA & 201.7 & 182 & 23 & 216.7 \\
\hline & $W 1$ & 215.7 & 207 & 217 & 224 & 208 & 215 & NA & 202.8 & 185 & 24 & 215.1 \\
\hline & W1 & 214.2 & 207 & 216 & 222 & 208 & 215 & NA & 203.6 & 188 & 25 & 213.7 \\
\hline & W1 & 212.8 & 207 & 215 & 220 & 208 & 214 & $\mathrm{NA}$ & 204.1 & 190 & 26 & 212.4 \\
\hline \multirow{8}{*}{ 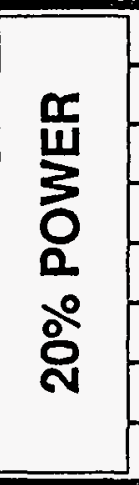 } & $20 \%$ W1 & 211.1 & 207 & 213 & 218 & 208 & 213 & NA & 204.7 & 193 & 28 & 210.8 \\
\hline & $W 1$ & 211.4 & 207 & 213 & 217 & 208 & 212 & NA & 205.0 & 194 & 29 & 210.3 \\
\hline & W1 & 210.0 & 207 & 213 & 216 & 208 & 212 & NA & 205.5 & 195 & 30 & 210.0 \\
\hline & W1 & 209.9 & 207 & 212 & 216 & 208 & 212 & NA & 205.6 & 196 & 31 & 209.9 \\
\hline & $W 1$ & 209.8 & 208 & 212 & 216 & 209 & 212 & NA & 205.9 & 197 & 31 & 209.9 \\
\hline & W1 & 209.9 & 208 & 212 & 216 & 209 & 212 & NA & 206.2 & 198 & 32 & 209.9 \\
\hline & W1 & 210.0 & 208 & 213 & 216 & 209 & 212 & NA & 206.7 & 198 & 34 & 210.0 \\
\hline & W1 & 210.2 & 209 & 213 & 216 & 209 & 212 & NA & 207.2 & 199 & 35 & 210.3 \\
\hline \multirow{9}{*}{ 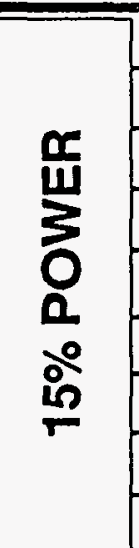 } & $15 \%$ W2 & 210.5 & 209 & 213 & 216 & 210 & 213 & NA & 207.8 & 200 & 38 & 210.6 \\
\hline & W1 & 210.5 & 209 & 213 & 216 & 200 & 213 & $N A$ & 207.9 & 200 & 39 & 210.5 \\
\hline & W1 & 210.5 & 209 & 213 & 216 & 200 & 212 & NA & 207.9 & 200 & 40 & 210.4 \\
\hline & W1. & 210.3 & 209 & 213 & 216 & 200 & 212 & NA & 208.1 & 201 & 41 & 210.3 \\
\hline & W1 & 210.2 & 209 & 213 & 215 & 200 & 212 & NA & 208.1 & 201 & 42 & 210.1 \\
\hline & W1 & 210.1 & 209 & 213 & 215 & 200 & 212 & NA & 208.1 & 201 & 43 & 210.0 \\
\hline & W1 & 210.0 & 209 & 213 & 215 & 200 & 212 & NA & 208.1 & 201 & 44 & 209.9 \\
\hline & W1 & 209.8 & 209 & 212 & 215 & 200 & 212 & $\mathrm{NA}$ & 208.0 & 201 & 45 & 209.7 \\
\hline & W10 & 208.1 & 208 & 211 & 213 & 208 & 210 & NA & 206.9 & 200 & 55 & 208.0 \\
\hline $17 \%$ & W10 & 207.4 & 207 & 210 & 212 & 207 & 209 & NA & 206.0 & 199 & 65 & 207.4 \\
\hline $20 \%$ & W15 & 210.1 & 208 & 212 & 214 & 209 & 211 & $\mathrm{NA}$ & 207.7 & 200 & 80 & 210.1 \\
\hline \multicolumn{13}{|c|}{$\begin{array}{l}\text { Comments: } \\
\text { OA }=\text { Power Off At temperature. } \quad W 1=\text { Wait } 1 \text { minute before recording temperatures. } \\
\text { Readings were taken from left to right starting and finishing. With the "control" thermocouple. }\end{array}$} \\
\hline
\end{tabular}


Table A-6.

CA Fix. I Eval $-50^{\circ}$

\section{Crack Arrest Fixture Temperature Gradient}

Room Temp. $77^{\circ} \mathrm{F}$

$1=$ Ten Front

5=Bottem middle
$2=$ Top Middle

$6=$ Bottem back
$3=$ Top Rear

$Z=$ Side middle
(TEMP PROB NOT RESEATED)

$4=$ Bottem from

$8=$ Hole

Target Temp. $-50^{\circ} \mathrm{C} /-58^{\circ} \mathrm{F}$

\begin{tabular}{|c|c|c|c|c|c|c|c|c|c|c|c|}
\hline OA Temp. & Control & & & & rmo & uple & & & & & \\
\hline$\& W 1$ & Temp & 1 & 2 & 3 & 4 & 5 & 6 & 7 & 8 & Time & Temp \\
\hline-58 & -54.7 & -45 & -51 & -54 & -43 & -51 & NA & -46.1 & -34 & 9 & -52.7 \\
\hline W1 & -50.7 & -44 & -49 & -51 & -42 & -49 & NA & -44.9 & -35 & 10 & -49.3 \\
\hline-58 & -55.9 & -48 & -52 & -55 & -46 & -53 & NA & -49.8 & -40 & 12 & -54.2 \\
\hline W1 & -52.4 & -48 & -51 & -52 & -46 & -51 & NA & -49.0 & -41 & 13 & -51.5 \\
\hline-59 & -56.8 & -51 & -54 & -56 & -49 & -55 & NA & -52.0 & -45 & 15 & .55 .6 \\
\hline W1 & -53.9 & -50 & -53 & -53 & -48 & -53 & NA & -51.5 & -45 & 16 & \\
\hline-59 & -57.6 & -52 & -55 & -56 & -50 & -56 & $\overline{N A}$ & -54.0 & -48 & 18 & -56.4 \\
\hline W1 & -54.8 & -52 & -53 & -54 & -49 & -54 & NA & -53.4 & -47 & 19 & -54 \\
\hline-60 & -58.1 & -54 & -56 & -57 & -51 & -57 & NA & -55.4 & -49 & 22 & -57.2 \\
\hline W1 & -55.5 & -53 & -55 & -55 & -51 & -55 & NA & -54.7 & -49 & 23 & \\
\hline-60 & -58.4 & -54 & -56 & -57 & -52 & -57 & NA & -56.4 & -51 & 25 & -57.7 \\
\hline W1 & -56.1 & -54 & -55 & -55 & -51 & -56 & NA & -55.8 & -50 & 26 & -55.6 \\
\hline-61 & -60.1 & -56 & -58 & -59 & -54 & -59 & NA & -57.8 & -52 & 28 & -59.1 \\
\hline W1 & -57.8 & -55 & -57 & -57 & -53 & -57 & NA & -57.2 & -52 & 29 & -57.3 \\
\hline-61 & -60 & -56 & -58 & -58 & -54 & -59 & NA & -58.4 & -53 & 31 & -59.2 \\
\hline W1 & -58 & -55 & -57 & -57 & -53 & -57 & NA & -57.8 & -53 & 32 & -57.4 \\
\hline-61 & -60.1 & -56 & -58 & -58 & -54 & -59 & NA & -58.8 & -54 & 34 & -59.3 \\
\hline W1 & -58 & -56 & -57 & -57 & -53 & -57 & $\overline{N A}$ & -58.0 & -53 & 35 & -57.5 \\
\hline-62 & -60.8 & -58 & -58 & -59 & .56 & -60 & NA & -60.2 & -55 & 38 & -60.2 \\
\hline W1 & -59.1 & -57 & -57 & -57 & -54 & -58 & NA & -59.5 & -54 & 39 & -58.5 \\
\hline-62 & -61.4 & -57 & -59 & -59 & -55 & -60 & NA & -59.9 & -55 & 42 & -60.7 \\
\hline$W_{1}$ & -59.1 & -57 & -57 & -57 & -54 & -58 & NA & -59.4 & -55 & 43 & -58.5 \\
\hline-62 & -61.4 & -58 & -59 & -59 & -55 & -60 & NA & -60.4 & -55 & 45 & -60.7 \\
\hline$W 1$ & -59.1 & -57 & -58 & -58 & -54 & -59 & NA & -59.8 & -55 & 46 & -59 \\
\hline
\end{tabular}

Comments: OA Temp \& W1 -

SPECIMEN IN INVERTED PQSITION

$O A=O f f A t$, the temperature the $L N$ was turned off. Each time the nitrogen was turned off, temperature readings were not taken until 1 minute had elapsed.

W1 1 Wait 1 minute before recoroing temperatures. After the first temps. were recorded and before the nitrogen was turned back on another recording was made 60 seconds after the first.

Test wedge WAS NOT inserted into the specimen during temperature evaluations.

Readings were taken from left to right starting and finishing with the "control" thermocouple. 
Table A-7.

CA Fix. I Eval $0^{\circ}$

\section{Crack Arrest Fixture Temperature Gradient}

Room Temp. $77^{\circ} \mathrm{F}$

1=Tep Front

$5=$ Bottom middle
Thermocouple locations

$2=$ Top Middle

$6=$ Bottom back
$3=$ Top Rear

Z=Side middle
(TEMP PROB NOT RESEATED)

$4=$ Bottem front

$8=$ Hole

Target Temp. $0^{\circ} \mathrm{C} / 32^{\circ} \mathrm{F}$

\begin{tabular}{|c|c|c|c|c|c|c|c|c|c|c|c|}
\hline \multirow{2}{*}{$\begin{array}{c}\text { OA Temp } \\
\& W 1\end{array}$} & \multirow{2}{*}{$\begin{array}{c}\text { Control } \\
\text { Temp }\end{array}$} & \multicolumn{8}{|c|}{ Thermocouples of } & \multirow[b]{2}{*}{ Time } & \multirow{2}{*}{$\begin{array}{r}\text { Control } \\
\text { Temp }\end{array}$} \\
\hline & & 1 & 2 & 3 & 4 & 5 & 6 & 7 & 8 & & \\
\hline 31.5 & 31.9 & 35 & 33 & 32 & 36 & 33 & NA & 34.8 & 38 & 034 & 32.1 \\
\hline 31.5 & 31.8 & 35 & 33 & 32 & 36 & 33 & NA & 34.7 & 37 & 36 & 32.0 \\
\hline 31.5 & 31.7 & 34 & 33 & 32 & 36 & 33 & NA & 34.3 & 37 & 38 & 31.8 \\
\hline$W_{1}$ & 32.0 & 35 & 34 & 33 & 36 & 33 & NA & 34.4 & 37 & 39 & 32.2 \\
\hline 31.5 (W2) & 31.9 & 35 & 34 & 33 & 36 & 33 & NA & 34.2 & 36 & 42 & 32.0 \\
\hline 31.0 & 31.7 & 34 & 32 & 32 & 35 & 32 & NA & 33.2 & 36 & 44 & 30.9 \\
\hline$W 1$ & 31.1 & 34 & 33 & 32 & 35 & 32 & NA & 33.2 & 36 & 45 & 31.3 \\
\hline W1 & 31.5 & 34 & 33 & 33 & 35 & 33 & NA & 33.4 & 36 & 46 & 31.7 \\
\hline W1 & 31.9 & 34 & 34 & 34 & 36 & 33 & NA & 33.7 & 36 & 47 & 32.0 \\
\hline 30.0 & 31.3 & 33 & 32 & 32 & 35 & 32 & NA & 32.5 & 35 & 51 & 30.5 \\
\hline W1 & 31.7 & 33 & 32 & 32 & 35 & 32 & NA & 32.7 & 35 & 52 & 30.9 \\
\hline 30.0 & 31.4 & 33 & 32 & 32 & 35 & 32 & NA & 32.4 & 34 & 54 & 30.4 \\
\hline W1 & 31.8 & 33 & 33 & 33 & 35 & 32 & NA & 32.6 & 34 & 55 & 31.0 \\
\hline 30.0 & 31.4 & 33 & 32 & 32 & 35 & 32 & NA & 32.2 & 34 & 57 & 30.5 \\
\hline W1 & 31.8 & 33 & 33 & 33 & 35 & 32 & $\overline{N A}$ & 32.5 & 34 & 58 & 30.9 \\
\hline & & & & & & & & & & & \\
\hline & & & & & & & & & & & \\
\hline & & & & & & & & & & & \\
\hline & & & & & & & & & & & \\
\hline & & & & & & & & & & & \\
\hline & & & & & & & & & & & \\
\hline & & & & & & & & & & & \\
\hline & & & & & & & & & & & \\
\hline $\begin{array}{r}\text { Comme } \\
\text { OA } \\
\text { readings } \\
\text { W1 } \\
\text { nitrogen } \\
\text { Test wad } \\
\text { Readlngs }\end{array}$ & $\begin{array}{l}\text { nts: OA T } \\
=\text { Off At, the } \\
\text { were not tak } \\
=\text { Wait } 1 \text { mint } \\
\text { vas turned b } \\
\text { ge WAS NOT } \\
\text { were taken } f\end{array}$ & $p$ \& & to the & cime & d. & $\begin{array}{r}\text { SF } \\
\text { Each }\end{array}$ & CIMEI & $\begin{array}{l}\text { ro the } 1 \\
\text { tlons. } \\
\text { l" the }\end{array}$ & TED & $\begin{array}{l}\text { 2SITION } \\
\text { ed off, te }\end{array}$ & mperature \\
\hline
\end{tabular}


Table A-8.

CA Fix. I Eval $-50 \%$ wedge

Crack Arrest Fixture Temperature Gradient

Room Temp. $77^{\circ} \mathrm{F}$

1=Tep Front
$5=$ Bottem middle

Thermecouple lecations

\author{
2=Top Middle
}

6=Bottem back

Target Temp. $-50^{\circ} \mathrm{C} /-58^{\circ} \mathrm{F}$
(TEMP PROB RESEATED)

$4=$ Bottem iront

$8=$ Hole

\begin{tabular}{|c|c|c|c|c|c|c|c|c|c|c|c|}
\hline \multirow{2}{*}{$\begin{array}{c}\text { OA Temp } \\
\& W 1\end{array}$} & \multirow{2}{*}{$\begin{array}{c}\text { Control } \\
\text { Temp }\end{array}$} & \multicolumn{8}{|c|}{ Thermocouples ${ }^{\circ} \mathrm{F}$} & \multirow[b]{2}{*}{ Time } & \multirow{2}{*}{$\begin{array}{r}\text { Control } \\
\text { Temp }\end{array}$} \\
\hline & & 1 & 2 & 3 & 4 & 5 & 6 & 7 & 8 & & \\
\hline-62 & -57.9 & -56 & -59 & -60 & -54 & -59 & NA & -57.8 & -50 & 52 & -55.7 \\
\hline W1 & -52.8 & -56 & -57 & -57 & -53 & -58 & NA & 6.8 & -50 & 53 & -51.3 \\
\hline-62 & -58.1 & -56 & -58 & -59 & -54 & -59 & NA & 7.9 & -51 & 55 & -56.1 \\
\hline W1 & -53.0 & -55 & -57 & -57 & -53 & -58 & NA & 7.1 & -51 & 56 & -51.8 \\
\hline-62 & -57.6 & -56 & -58 & -59 & -54 & -59 & $\mathrm{NA}$ & 8.2 & -52 & 58 & -55.7 \\
\hline W1 & -53.2 & -55 & -57 & -57 & -53 & -58 & NA & 7.5 & -52 & 59 & -51.8 \\
\hline-62 & -58.9 & -57 & -59 & -59 & -55 & -60 & NA & 9.0 & -53 & 63 & -56.7 \\
\hline W1 & -55.0 & -56 & -58 & -58 & -54 & -59 & $\overline{N A}$ & 8.6 & -53 & 64 & -53.3 \\
\hline-62 & -58.8 & -58 & -59 & -59 & -55 & -60 & NA & 9.8 & -54 & 67 & -56.4 \\
\hline W1 & -53.4 & -57 & -58 & -58 & -55 & -59 & NA & 9.0 & -54 & 68 & -52.0 \\
\hline-62 & -59.1 & -58 & -59 & -60 & -56 & -60 & NA & 60.4 & -55 & 70 & -57.0 \\
\hline W1 & -53.9 & -57 & -58 & -58 & -56 & -59 & NA & 59.6 & -54 & 71 & -52.7 \\
\hline-62 & -58.9 & -58 & -60 & -60 & -56 & -61 & NA & 60.7 & -56 & 74 & -57.1 \\
\hline W1 & -54.3 & -58 & -59 & -59 & -55 & -60 & NA & 0.2 & -55 & 75 & -53.2 \\
\hline & & & & & & & & & & & \\
\hline & & & & & & & & & & & \\
\hline & & & & & & & & & & & \\
\hline & & & & & & & & & & & \\
\hline & & & & & & & & & & & \\
\hline & & & & & & & & & & & \\
\hline & & & & & & & & & & & \\
\hline & & & & & & & & & & & \\
\hline & & & & & & & & & & & \\
\hline \multicolumn{12}{|c|}{$\begin{array}{l}\text { SPECIMEN IN INVERTED PQSITION } \\
\text { OA } \\
\text { OA = Off At, the temperature the LN was turned off. Each time the nitrogen was turned off, temperature } \\
\text { readings were not taken until } 1 \text { minute had elapsed. } \\
\text { W1 } 1=\text { Wait } 1 \text { minute before recording temperatures. After the first temps. were recorded and before the } \\
\text { nitrogen was turned back on another recording was made } 60 \text { seconds after the first. } \\
\text { Test wedge WAS in the specimen during temperature evaluations. } \\
\text { Readings were taken from lett to right starting and tinishing with the "control" thermocouple. }\end{array}$} \\
\hline
\end{tabular}


Appendix B

\section{Design Details of Clip-Gage Blocks}




\section{Appendix B Design Details of Clip-Gage Blocks}

This appendix gives details about the clip-gage blocks that were designed to be attached remotely to the irradiated crack-arrest specimens. Figures B-1 and B-2 show these blocks and their attachment screws for the small and large specimens, respectively. In the case of the small specimen, the conical recess intended to receive the clipgage points had to be offset from the centerline of the specimen so as not to interfere with the hole for attaching the block to the specimen. The reduced shank of the socket-head cap screw for the smaller block was also necessitated by dimensional constraints, but it also considerably facilitated the assembly of the blocks. The cap screws for both sizes of clip-gage blocks were made from a high-strength steel and then hardened to minimize the possibility of inadvertently twisting off the head of such a small screw while it is being tightened by the manipulators. After attaching the clip-gage blocks to the specimen and tightening the screws snugly, the assembly was placed flat on a plane surface and, if necessary, the gage blocks were tapped so that they were in proper alignment on the specimen; then the final tightening of the screws of gage blocks was performed.

The gap between the faces containing the conical recesses on the installed clip-gage blocks is smaller thali the distance over the completely compressed clip-gage points. To insert the clip-gage, it was first completely compressed until both arms were in contact, then one of the conical points was inserted. This allowed the other point to be inserted. The depth of the conical recesses and the dimension over the completely compressed clipgage points were such that even after a crack-mouth opening displacement of $2.5 \mathrm{~mm}$ ( $100 \mathrm{mils})$, the completely compressed gage had to be manipulated for removal in the same manner used to insert the gage. The purpose of this design is to minimize the probability of the clip-gage jumping out of the blocks during a sudden crack jump, which would make the test useless.

The sequence for attaching the clip-gage block to the small specimens is as follows. The cap screw is first screwed into the specimen until the threaded part is below the front face of the specimen. The U-shaped opening in the clipgage block is then slipped onto the reduced shank of the cap screw, which is then tightened.

The design of the clip-gage blocks for large specimens was slightly different from that for the small specimens. It was believed that their relatively larger size would make them easier to handle, and two U-openings for the cap screws were thought to be unnecessary. In hindsight, this was a mistake, and such openings would have made their mounting much easier.

To minimize the amount of contaminated waste generated, only a minimum number of clip-gage blocks were placed in the hot cell. This necessitated the removal of these blocks after the handling of the specimen was completed. Incidentally, the blocks were also useful as pickup points for removing the specimen from the pan containing liquid nitrogen and back-putting it into the test machine to break it open to measure the crack jump. 
CONICAL HOLE $60^{\circ} \times 0.100 \mathrm{dp}$, ROOT AS SHARP AS

POSSIBLE (0.005R or less)

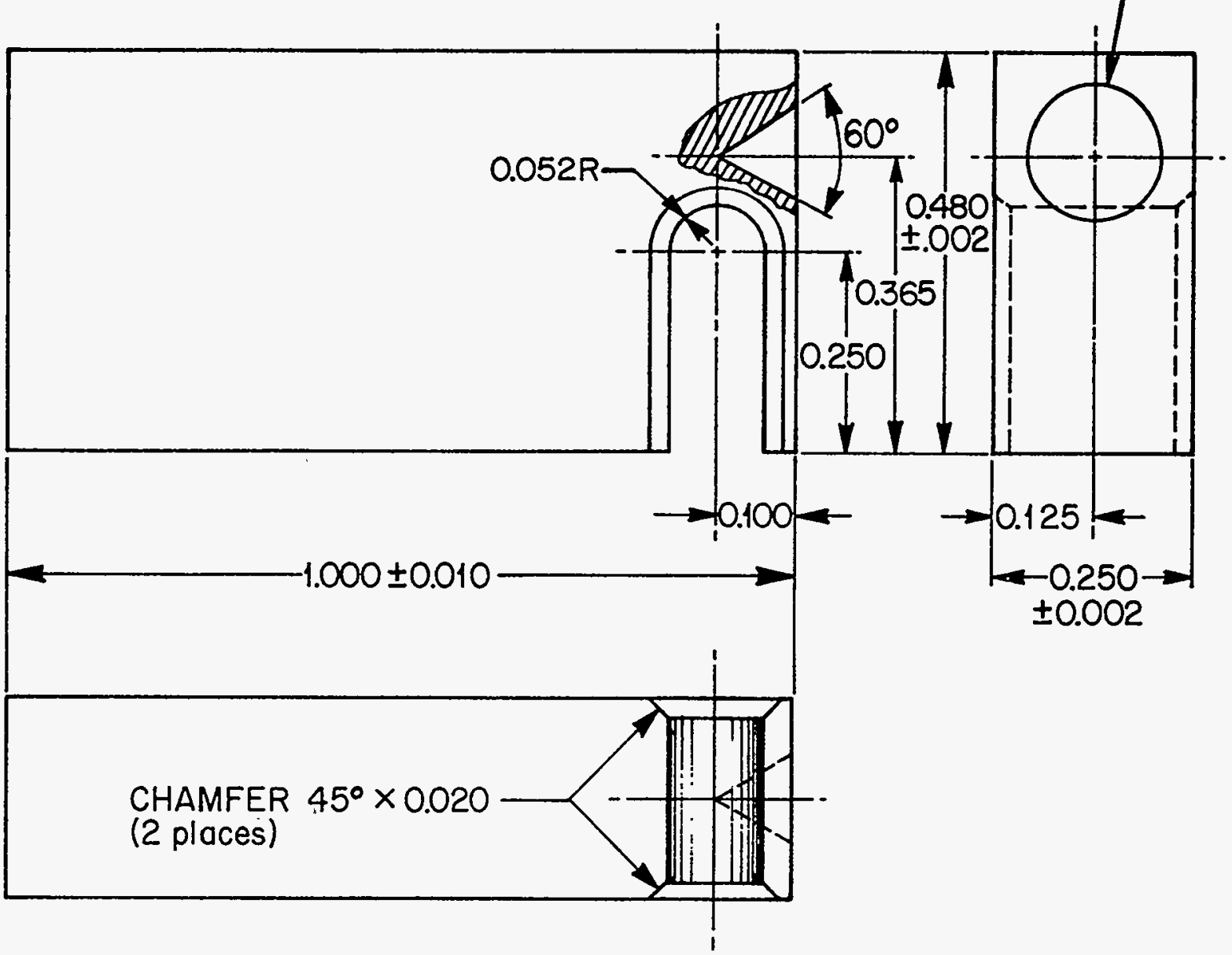

CLIP GAGE BLOCK FOR $1 / 2$ in. ENEA CRACK-ARREST SPECIMEN

ALL DIMENSIONS IN INCHES

MATERIAL: ANY STRUCTURAL STEEL (A-36 for example)

NUMBER REQUIRED: 4

Figure B-1(a). 


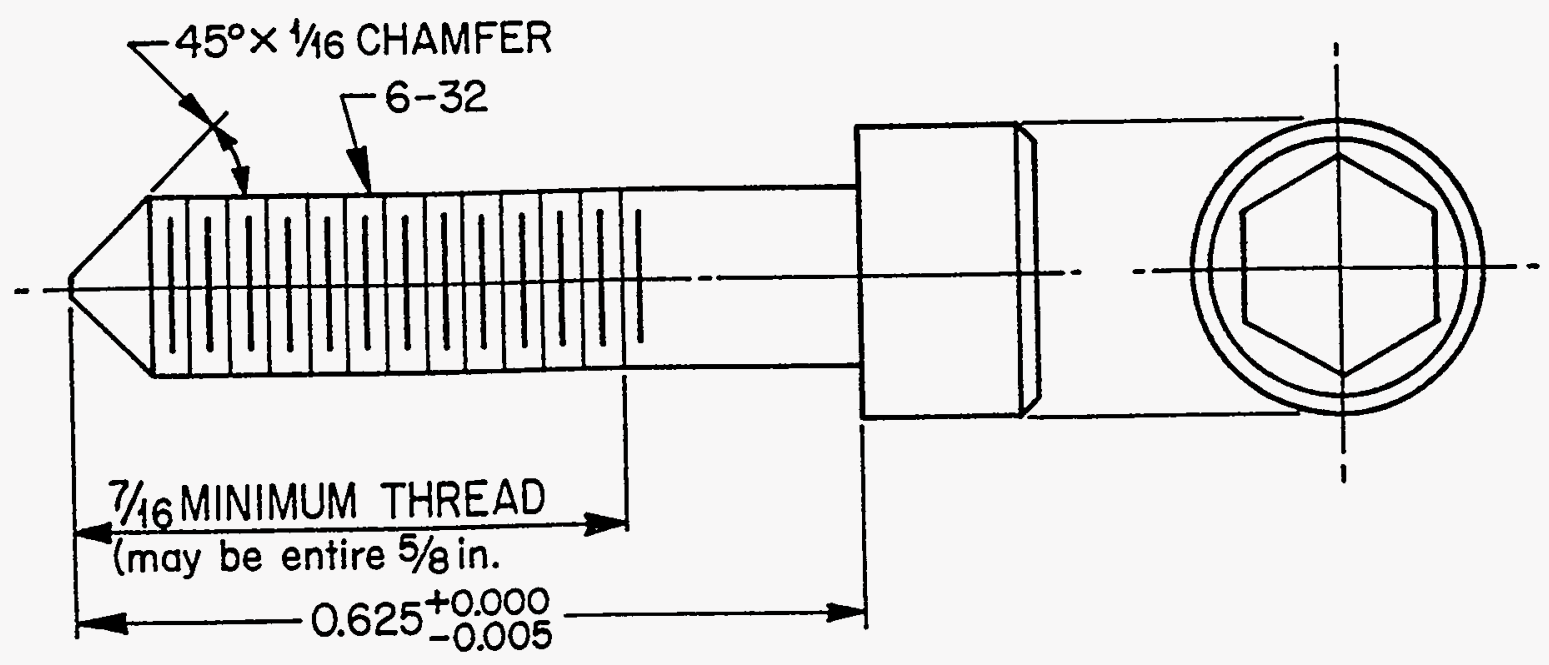

6-32 ALLEN SOCKET HEAD CAP SCREW MATERIAL: HARDENED STEEL NUMBER REQUIRED: 18 ALL DIMENSIONS IN INCHES

FOR USE WITH 1" ENEA IRRADIATED CRACK-ARREST SPECIMEN CLIP GAGE BLOCKS

Figure $\mathbf{B - 1}(\boldsymbol{b})$. 


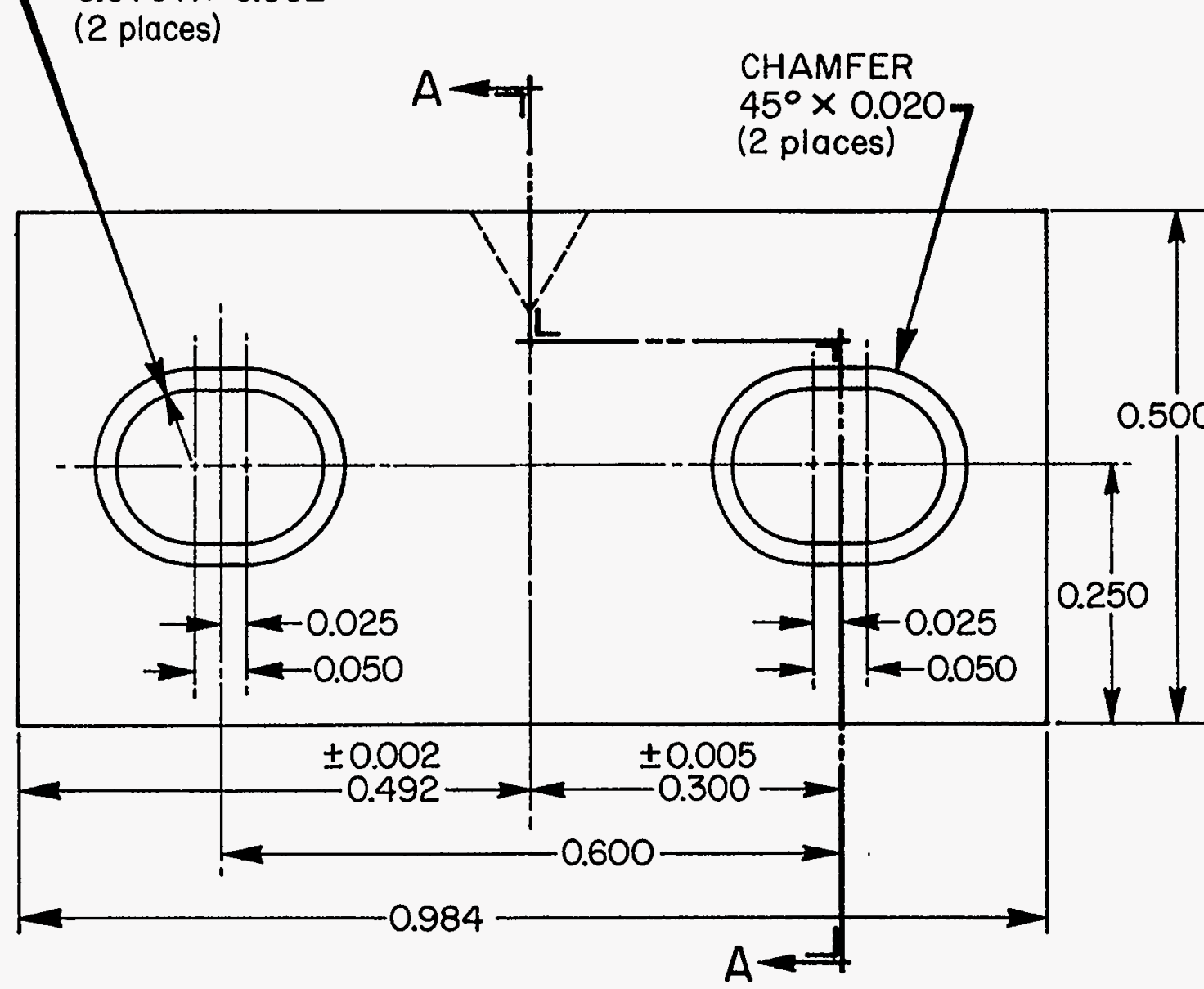

CONICAL HOLE $60^{\circ} \times 0.100$ DEEP BOTTOM RADIUS $<0.005$

r

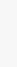

CLIP GAGE BLOCK FOR 1 in. ENEA SPECIMENS

NUMBER REQUIRED: 4 ALL DIMENSIONS IN INCHES

MATERIAL: ANY STRUCTURAL STEEL (A-36 for example) 


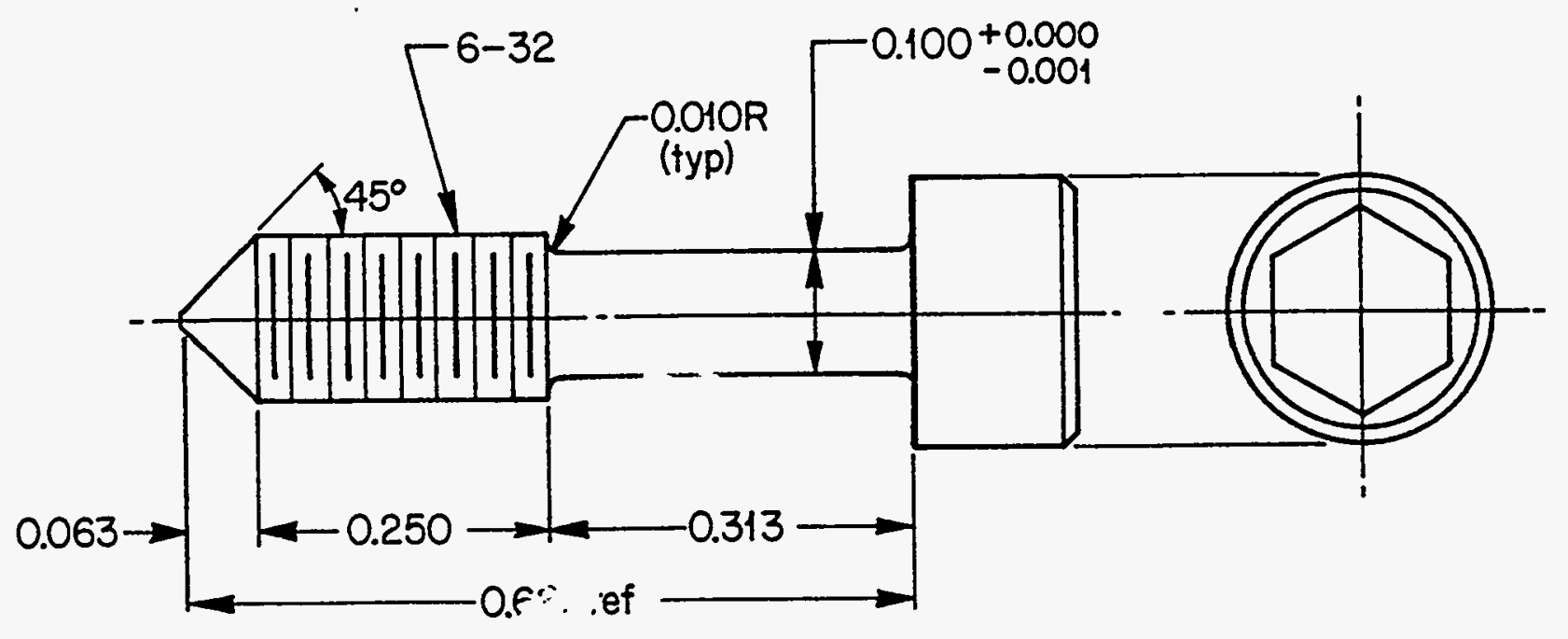

SPECIAL 6-32 ALLEN SOCKET HEAD CAP SCREW

MATERIAL: HARDENED STEEL

NUMBER REQUIRED: 18

ALL DIMENSIONS IN INCHES

FOR USE WITH 1" ENEA IRRADIATED CRACK-ARREST SPECIMEN CLIP GAGE BLOCKS

Figure $B-2(b)$. 


\section{Appendix C}

Pretest and Post-Test Calculations

According to ASTM E 1221-88 
$\therefore \cdots$ 


\section{Appendix C \\ Pretest and Post-Test Calculations According to ASTM E 1221-88}

The specimen dimensions; the intermediate calculations of crack-mouth opening displacement (CMOD) at initiation and arrest; and the outcome of calculations of the validity criteria according to ASTME 1221-88, $K_{0}$, and $K_{a}$, etc., are shown in this appendix in Table $\mathrm{C}-1$ in the form of a spreadsheet. The nomenclature used in the column headings for the specimen dimensions is defined in Figure 1 in the main body of this report. The validity criteria used in Table C-1 and excerpted from ASTM E 1221-88 were given in Table 8 of this report. The BASIC routines for the formulae for calculating the yield strength, Young's modulus, the specimen compliance calibration function, and the maximum CMOD during loading are shown in Table C-2. Tables $C-3$ and $C-4$ give other BASIC routines used to adjust the measured CMOD and the test temperature, respectively. 


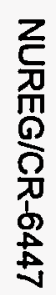

Table C-1. Detailed pre- and post-test data for the ANPA crack-arrest specimens, test results, and validity criteria

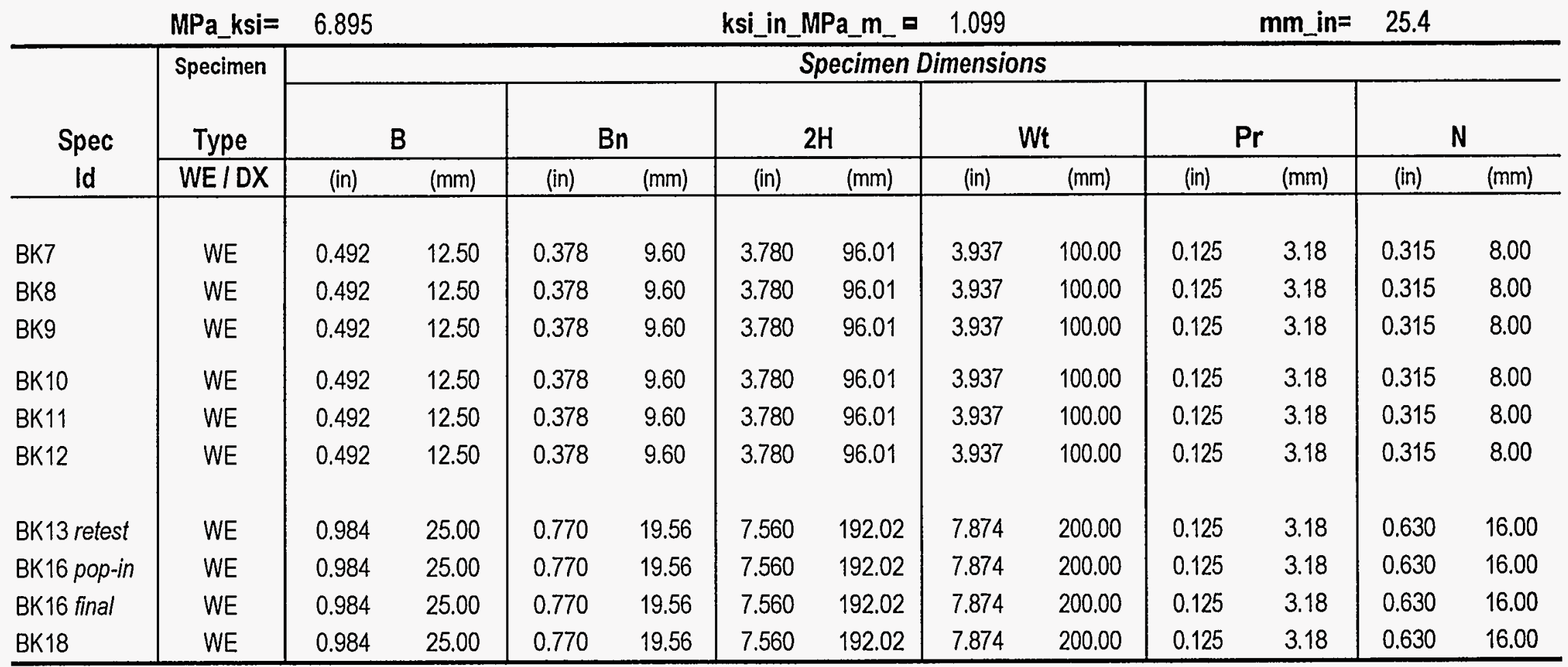

Check on tabular values of yield

Check on tabular values of $E$

\begin{tabular}{cccc}
\multicolumn{2}{c}{ Temperature } & \multicolumn{2}{c}{ Yield Strength } \\
$\left({ }^{\circ} \mathrm{C}\right)$ & $\left({ }^{\circ} \mathrm{F}\right)$ & $(\mathrm{ksi})$ & $(\mathrm{MPa})$ \\
25 & 77 & 72.4 & 499.2 \\
150 & 302 & 65.3 & 450.2
\end{tabular}

Temperature Young's Modulus

$\begin{array}{cccc}\left({ }^{\circ} \mathrm{C}\right) & \left({ }^{\circ} \mathrm{F}\right) & (\mathrm{ksi}) & (\mathrm{MPa}) \\ 21.1 & 70.0 & 29.88 & 206.0\end{array}$


Table C-1 (continued)

\begin{tabular}{|c|c|c|c|c|c|c|c|c|c|c|c|c|c|}
\hline \multirow[b]{2}{*}{$\begin{array}{c}\text { Spec } \\
\text { Id }\end{array}$} & \multicolumn{7}{|c|}{ Preliminary Calculations } & \multicolumn{6}{|c|}{ Dimensional Checks } \\
\hline & $\begin{array}{c}\text { Dist to } \mathrm{CL} \\
\text { (in) }\end{array}$ & $\begin{array}{c}\text { Hole dia } \\
\text { (in) }\end{array}$ & $\begin{array}{l}W \\
\text { (in) }\end{array}$ & $\begin{array}{c}\text { a0 } \\
\text { (in) }\end{array}$ & $\begin{array}{c}\mathrm{ff} \\
\text { (in) }\end{array}$ & aON & $f(a O N)$ & \multicolumn{2}{|c|}{ ff / W } & \multicolumn{2}{|c|}{$\mathrm{a} 0 / \mathrm{W}$} & \multicolumn{2}{|c|}{$\mathrm{Bn} / \mathrm{B}$} \\
\hline BK7 & 0.787 & 0.834 & 3.150 & 1.102 & 0.912 & 0.350 & 0.2477 & 0.290 & Check!! & 0.350 & OK & 0.768 & Check!! \\
\hline BK8 & 0.787 & 0.834 & 3.150 & 1.102 & 0.912 & 0.350 & 0.2477 & 0.290 & Check!! & 0.350 & OK & 0.768 & Check!! \\
\hline BK9 & 0.787 & 0.834 & 3.150 & 1.102 & 0.912 & 0.350 & 0.2477 & 0.290 & Check!! & 0.350 & OK & 0.768 & Check!! \\
\hline BK10 & 0.787 & 0.834 & 3.150 & 1.102 & 0.912 & 0.350 & 0.2477 & 0.290 & Check!! & 0.350 & OK & 0.768 & Check!! \\
\hline BK11 & 0.787 & 0.834 & 3.150 & 1.102 & 0.912 & 0.350 & 0.2477 & 0.290 & Check!! & 0.350 & OK & 0.768 & Check!! \\
\hline BK12 & 0.787 & 0.834 & 3.150 & 1.102 & 0.912 & 0.350 & 0.2477 & 0.290 & Check!! & 0.350 & OK & 0.768 & Check!! \\
\hline BK13 retest & 1.574 & 1.671 & 6.300 & 2.205 & 1.699 & 0.350 & 0.2477 & 0.270 & Check!! & 0.350 & OK & 0.782 & Check!! \\
\hline BK16 pop-in & 1.574 & 1.671 & 6.300 & 2.205 & 1.699 & 0.350 & 0.2477 & 0.270 & Check!! & 0.350 & OK & 0.782 & Check!! \\
\hline BK16 final & 1.574 & 1.671 & 6.300 & 2.205 & 1.699 & 0.350 & 0.2477 & 0.270 & Check!! & 0.350 & OK & 0.782 & Check!! \\
\hline BK18 & 1.574 & 1.671 & 6.300 & 2.205 & 1.699 & 0.350 & 0.2477 & 0.270 & Check!! & 0.350 & OK & 0.782 & Check!! \\
\hline
\end{tabular}

10:35 AM 12/15/95

"CA test sheet" page 2 of 6

in file: 11_hssi lenea lcrack_ar IKA.XLS 


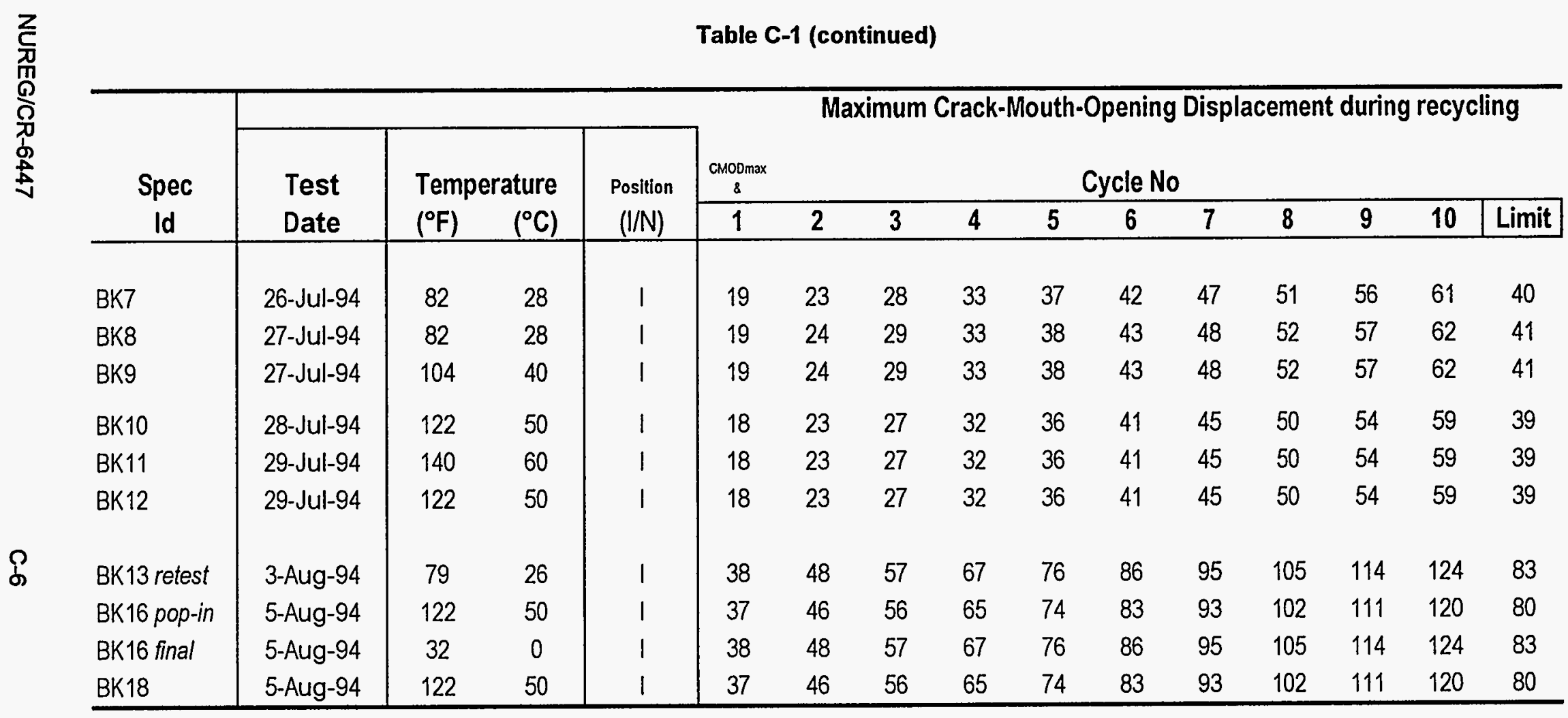

10:35 AM 12/15/95

"CA test sheet" page 3 of 6

in file: 11_hssi lenea lcrack_ar UKA.XLS 
Table C-1 (continued)

Test Results

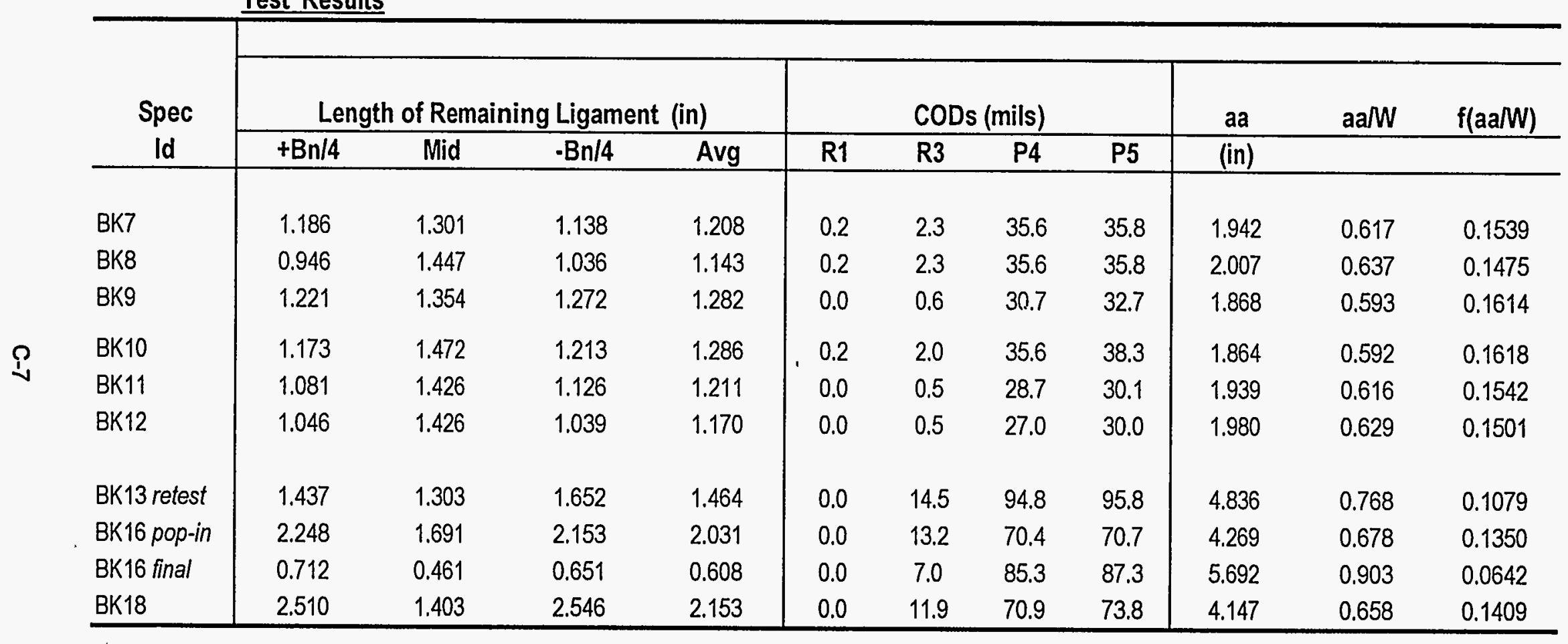

10:35 AM 12/15/95

"CA test sheet" page 4 of 6

in file: UI_hssi lenea lcrack_ar IKA.XLS 


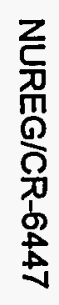

Table C-1 (continued)

Final Calculations

RTndt $=-1.5 \quad{ }^{\circ} \mathrm{C}$

\begin{tabular}{|c|c|c|c|c|c|c|c|c|c|c|c|c|c|c|c|c|}
\hline \multirow{3}{*}{$\begin{array}{l}\text { Spec } \\
\text { Id }\end{array}$} & \multicolumn{2}{|c|}{ Yield } & \multirow{3}{*}{$\begin{array}{c}E \\
k s i\end{array}$} & \multicolumn{2}{|c|}{ Measured } & \multicolumn{2}{|c|}{ Adjusted } & \multicolumn{6}{|c|}{ Stress Intensity Factors } & \multicolumn{3}{|c|}{ Loads } \\
\hline & \multirow{2}{*}{$\frac{\text { Static }}{\text { (ksi) }}$} & \multirow{2}{*}{$\begin{array}{r}\text { Dyn } \\
\text { (ksi) } \\
\end{array}$} & & \multirow{2}{*}{$\begin{array}{c}\mathrm{d} 0 \\
\text { (mils) }\end{array}$} & \multirow{2}{*}{$\begin{array}{c}d a \\
\text { (mils) }\end{array}$} & \multirow{2}{*}{$\begin{array}{c}\mathrm{d} 0 \\
\text { (mils) }\end{array}$} & \multirow{2}{*}{$\begin{array}{c}\mathrm{da} \\
\text { (mils) }\end{array}$} & \multicolumn{2}{|c|}{ KO } & \multicolumn{2}{|c|}{$\begin{array}{c}\text { Test } \\
\text { Temperature } \\
\end{array}$} & \multicolumn{2}{|c|}{$\mathrm{Ka}$} & \multirow{2}{*}{$\begin{array}{c}\text { Pmax } \\
\text { (lb) }\end{array}$} & \multirow{2}{*}{$\begin{array}{c}\text { Pmin } \\
\text { (lb) } \\
\end{array}$} & \multirow{2}{*}{$\frac{P \min }{P \max }$} \\
\hline & & & & & & & & (ksi|in) & $(\mathrm{MPa} a \mathrm{~m})$ & $\mathrm{T}\left({ }^{\circ} \mathrm{C}\right)$ & $T-R \operatorname{Tndt}(\mathrm{K})$ & (ksilin) & $(\mathrm{MPa} \mid \mathrm{m})$ & & & \\
\hline BK7 & 72.2 & 102.2 & 29821 & 33.3 & 34.5 & 32.0 & 33.2 & 151.8 & 166.8 & 28.0 & 29.5 & 98.0 & 107.7 & 1625 & 450 & 0.28 \\
\hline BK8 & 72.2 & 102.2 & 29821 & 33.3 & 34.5 & 32.0 & 33.2 & 151.8 & 166.8 & 28.0 & 29.5 & 93.9 & 103.2 & 1625 & 450 & 0.28 \\
\hline BK9 & 71.5 & 101.5 & 29722 & 30.1 & 31.4 & 28.9 & 30.3 & 136.8 & 150.3 & 40.0 & 41.5 & 93.3 & 102.5 & 1655 & 620 & 0.37 \\
\hline BK10 & 71.0 & 101.0 & 29639 & 33.6 & 35.8 & 32.3 & 34.5 & 152.3 & 167.4 & 50.0 & 51.5 & 106.4 & 116.9 & 2590 & 650 & 0.25 \\
\hline BK11 & 70.4 & 100.4 & 29556 & 28.2 & 29.2 & 27.1 & 28.1 & 127.4 & 140.0 & 60.0 & 61.5 & 82.3 & 90.4 & 1460 & 600 & 0.41 \\
\hline BK12 & 71.0 & 101.0 & 29639 & 26.5 & 28.3 & 25.4 & 27.2 & 120.1 & 132.0 & 50.0 & 51.5 & 77.9 & 85.6 & 1460 & 550 & 0.38 \\
\hline BK13 retest & 72.3 & 102.3 & 29838 & 80.3 & 88.1 & 78.7 & 86.5 & 261.9 & 287.8 & 26.0 & 27.5 & 125.4 & 137.8 & 15600 & 3000 & 0.19 \\
\hline BK16 pop-in & 71.0 & 101.0 & 29639 & 57.2 & 64.0 & 56.0 & 62.8 & 185.3 & 203.6 & 50.0 & 51.5 & 113.2 & 124.4 & 6300 & 5800 & 0.92 \\
\hline BK16 final & 73.8 & 103.8 & 30053 & 78.3 & 82.8 & 76.7 & 81.4 & 257.2 & 282.7 & 0.0 & 1.5 & 70.8 & 77.8 & 12430 & 0 & 0.00 \\
\hline BK18 & 71.0 & 101.0 & 29639 & 59.0 & 66.4 & 57.8 & 65.2 & 191.1 & 210.0 & 50.0 & 51.5 & 122.7 & 134.8 & 7960 & 3400 & 0.43 \\
\hline
\end{tabular}

10:35 AM 12/15/95

"CA test sheet" page 5 of 6

in file: 11_hssi lenea krack_ar IKA.XLS 
Table C-1 (continued)

\begin{tabular}{|c|c|c|c|c|c|c|c|c|c|c|c|c|c|c|c|c|c|c|c|c|}
\hline \multirow{4}{*}{$\begin{array}{c}\text { Spec } \\
\text { Id }\end{array}$} & \multirow{2}{*}{\multicolumn{8}{|c|}{ Unbroken Ligament }} & \multirow{2}{*}{\multicolumn{4}{|c|}{ Thickn }} & \multirow{2}{*}{\multicolumn{8}{|c|}{ Crack-jump length }} \\
\hline & & & & & & & & & & & & & & & & & & & & \\
\hline & \multicolumn{4}{|c|}{ (A) $0.15 \mathrm{~W}$} & \multicolumn{4}{|c|}{ (B) $1.25(\mathrm{Ka} / \mathrm{sigyd})^{2}$} & \multicolumn{4}{|c|}{ (C) $1.0(\mathrm{Ka} / \mathrm{sigyd})^{2}$} & \multicolumn{4}{|c|}{ (D) $2 \mathrm{~N}$ or $2 \mathrm{D}$} & \multicolumn{4}{|c|}{ (E) (K0/sigys) $)^{2}\left(2^{*} \mathrm{PI}\right)$} \\
\hline & W-aa & (a) & \multicolumn{2}{|c|}{ Valid ?* } & W-aa & (b) & \multicolumn{2}{|c|}{ Valid ?* } & $B$ & (c) & \multicolumn{2}{|c|}{ Valid ?* } & \multicolumn{4}{|c|}{$\begin{array}{ll}a a-a 0 & \text { (d) Valid ? } \\
\end{array}$} & \multicolumn{2}{|c|}{ aa- $a 0$ (e) } & \multicolumn{2}{|c|}{ Valid ?* } \\
\hline BK7 & 1.21 & 0.47 & 2.56 & & 1.21 & 1.15 & 1.05 & OK & 0.49 & 0.92 & 0.54 & Fails & 0.84 & 0.63 & 1.33 & OK & 0.84 & 0.70 & 1.19 & OK \\
\hline BK8 & 1.14 & 0.47 & 2.42 & & 1.14 & 1.05 & 1.08 & OK & 0.49 & 0.84 & 0.58 & Fails & 0.91 & 0.63 & 1.44 & OK & 0.91 & 0.70 & 1.29 & OK \\
\hline BK9 & 1.28 & 0.47 & 2.71 & OK & 1.28 & 1.06 & 1.21 & OK & 0.49 & 0.84 & 0.58 & Fails & 0.77 & 0.63 & 1.22 & OK & 0.77 & 0.58 & 1.32 & OK \\
\hline BK10 & 1.29 & 0.47 & 2.72 & OK & 1.29 & 1.39 & 0.93 & Fail & 0.49 & 1.11 & 0.44 & Fails & 0.76 & 0.63 & 1.21 & OK & 0.76 & 0.73 & 1.04 & OK \\
\hline BK11 & 1.21 & 0.47 & 2.56 & OK & 1.21 & 0.84 & 1.44 & OK & 0.49 & 0.67 & 0.73 & Fails & 0.84 & 0.63 & 1.33 & OK & 0.84 & 0.52 & 1.61 & OK \\
\hline BK12 & 1.17 & 0.47 & 2.48 & OK & 1.17 & 0.74 & 1.57 & OK & 0.49 & 0.60 & 0.83 & Fails & 0.88 & 0.63 & 1.39 & OK & 0.88 & 0.46 & 1.93 & OK \\
\hline BK13 retest & 1.46 & 0.95 & 1.55 & OK & 1.46 & 1.88 & 0.78 & Fail & 0.98 & 1.50 & 0.66 & Fails & 2.63 & 1.26 & 2.09 & OK & 2.63 & 2.09 & 1.26 & OK \\
\hline BK16 pop-in & 2.03 & 0.95 & 2.15 & OK & 2.03 & 1.57 & 1.29 & OK & 0.98 & 1.26 & 0.78 & Fails & 2.06 & 1.26 & 1.64 & OK & 2.06 & 1.08 & 1.90 & OK \\
\hline BK16 final & 0.61 & 0.95 & 0.64 & Fails & 0.61 & 0.58 & 1.05 & OK & 0.98 & 0.47 & 2.12 & OK & 3.49 & 1.26 & 2.77 & OK & 3.49 & 1.93 & 1.80 & OK \\
\hline BK18 & 2.15 & 0.95 & 2.28 & OK & 2.15 & 1.85 & 1.17 & OK & 0.98 & 1.48 & 0.67 & Fails & 1.94 & 1.26 & 1.54 & OK & 1.94 & 1.15 & 1.68 & OK \\
\hline
\end{tabular}

*The degree with which the particular validity criterion was met or not may be judged by the closeness to unity of ratio of values in the two previous columns. If the ratio $\geq 1$, validity is "OK", otherwise it "Fails" 


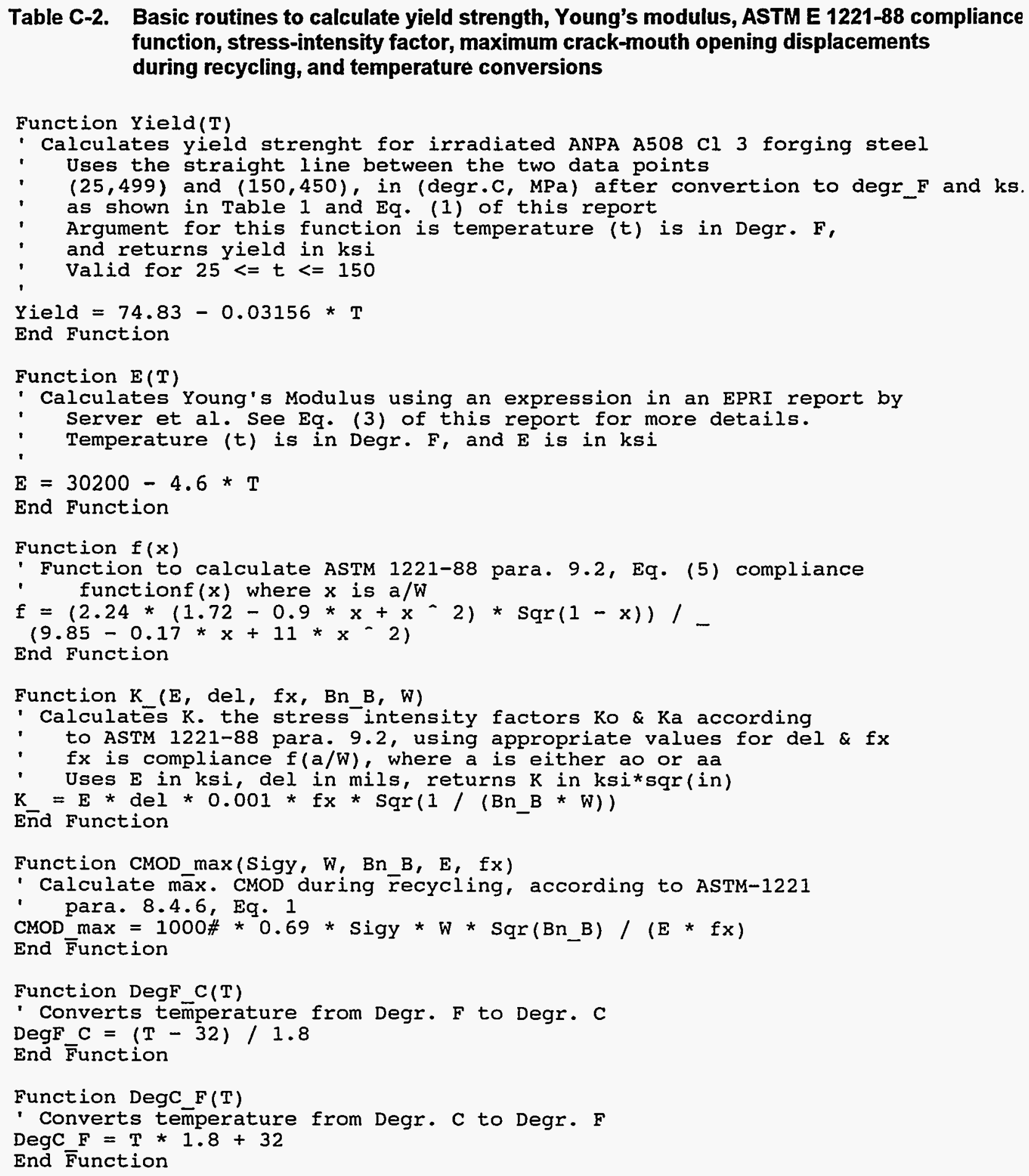


Table C-3. Basic routines to adjust measured crack-mouth opening displacement to front-face

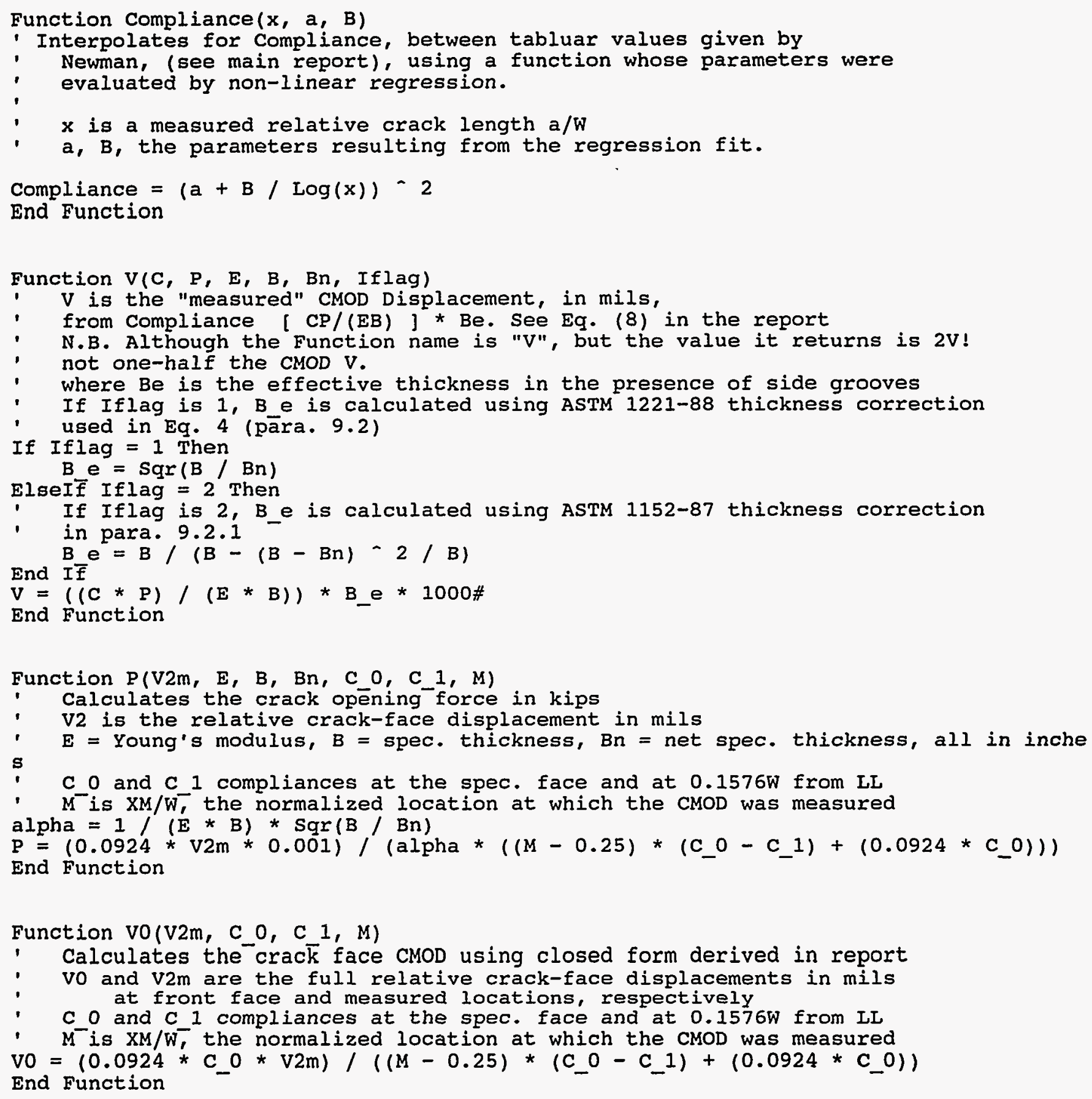

10:53 AM 12/15/95 Page 1 of 1

1_hssi lenea lcrack-arr IKA.XLS worksheet "Macros for Displ" 
Table C-4. Basic routines to adjust test temperature to the reference fluence and temperatures

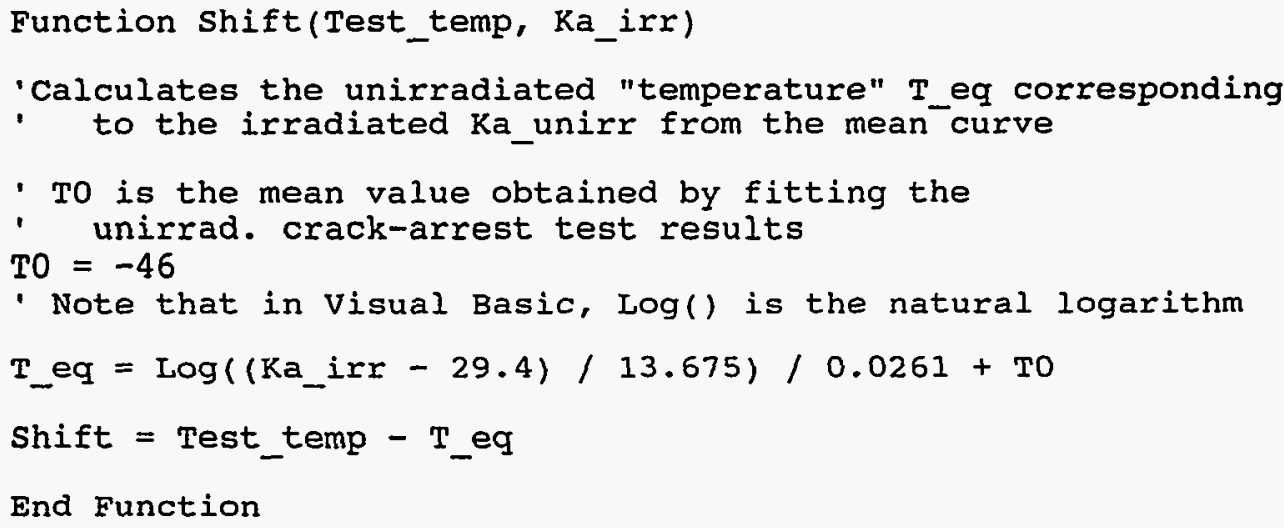

End If

End Function

Function Temp_corr(Ref_Irr_temp, Irr_temp)

- Corrects for actual temperature irradiation conditons

Temp_corr $=$ (Irr_temp - Ref_Irr_temp)

End Function

10:55 AM 12/15/95 Page 1 of 1

1_hssi lenea Icrack-arr IKA.XLS worksheet "Exp Adj Macros" 


\section{Appendix D \\ $X-Y$ Plotter Output and \\ Fracture Surfaces}


SרIW oaes

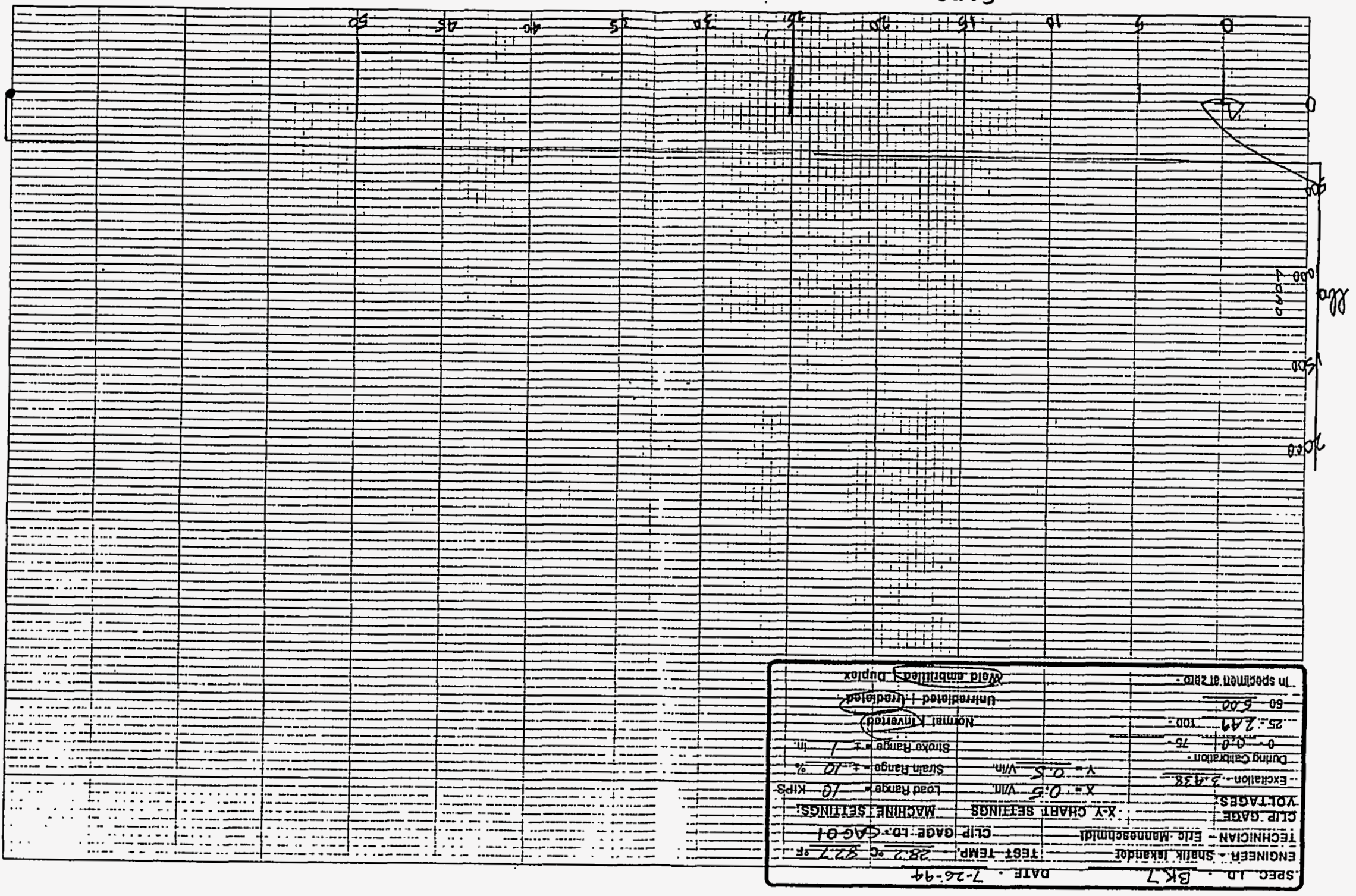




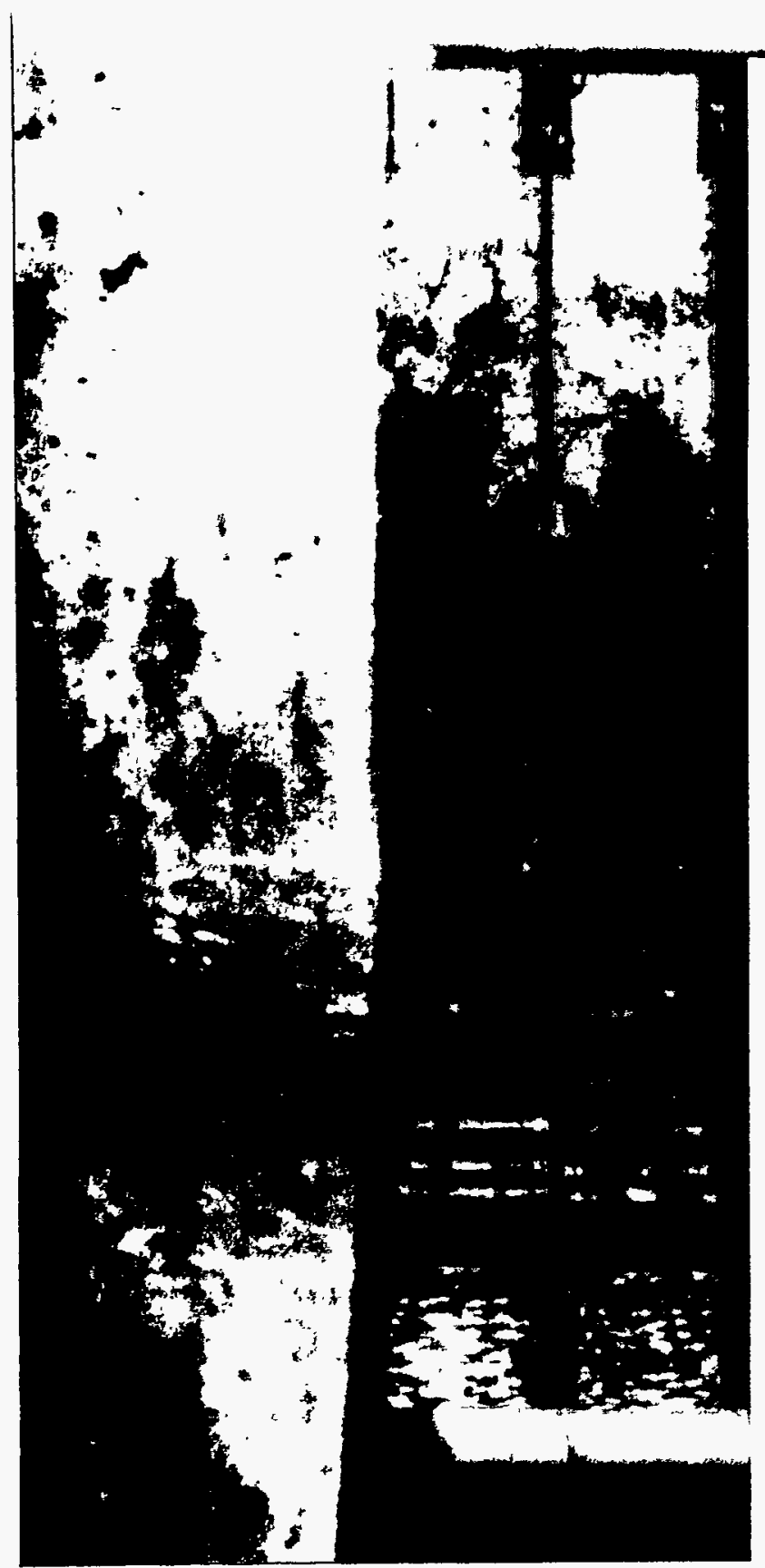


SPEC 10. BK8 DATE. 7.27 .94

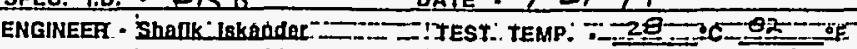

TECHNICIAN: Errie Männoschinldf = -

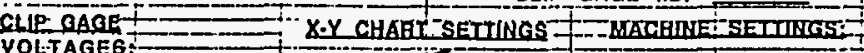

VOLLIAGEG:

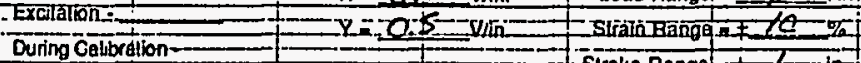

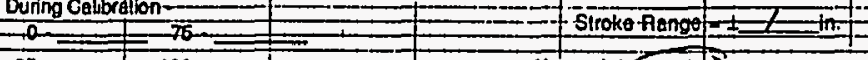

$25=700=$

$50=1+1=0$

in spectmen at zero=1 =

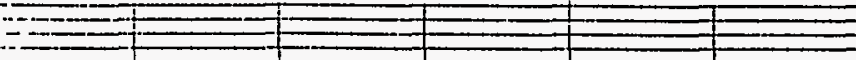

-

$=-0$

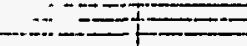

$=$

$=$

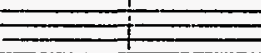

$\$$

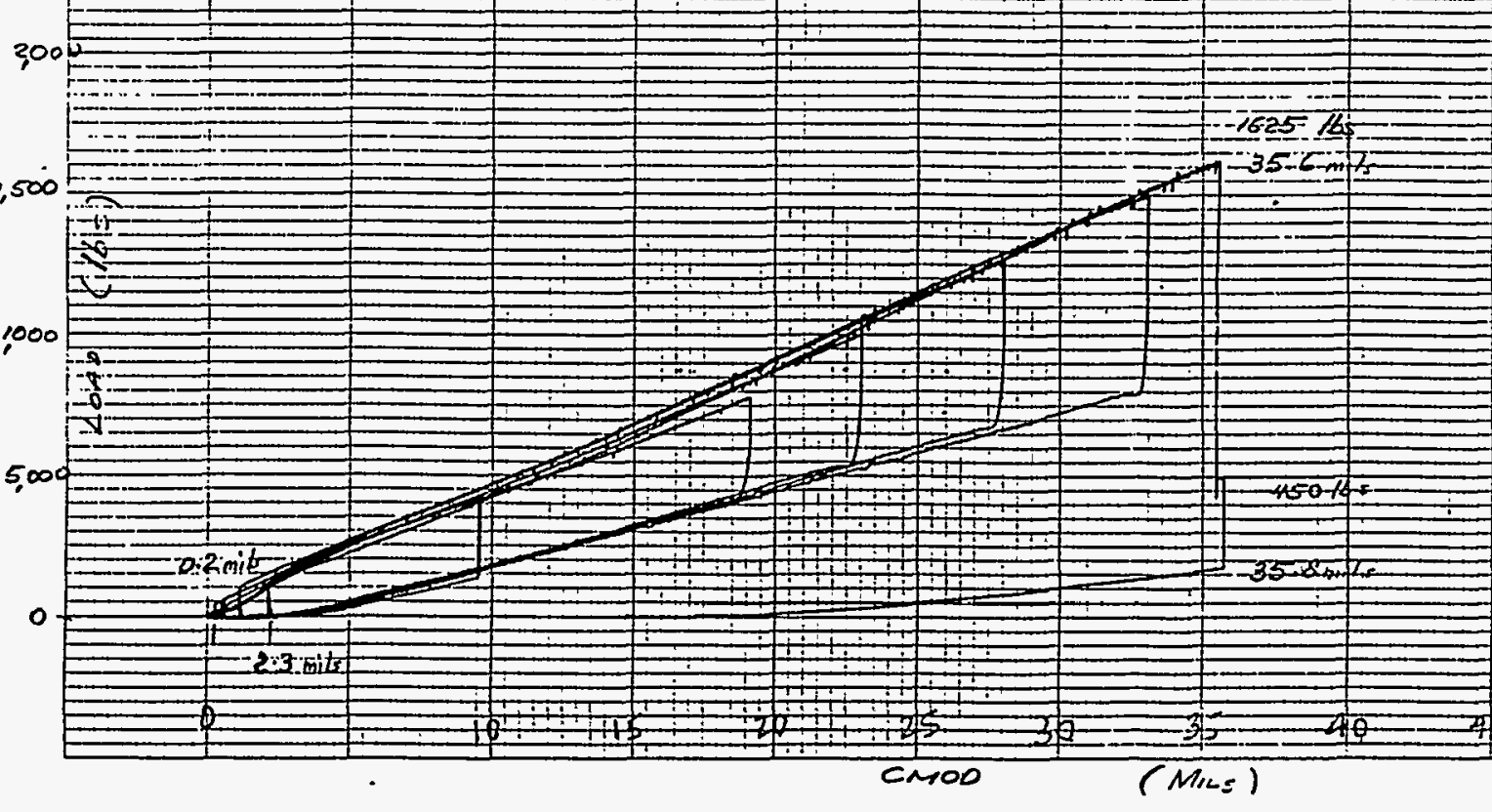
다.

c.g. disp $=20 \mathrm{mil} w /$ wedne int aftertest $j$. disp $=20$ mis w/ wede rut aftertert

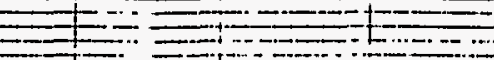
7

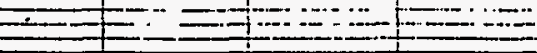
$\equiv=\equiv \pm=$ $=0-=$

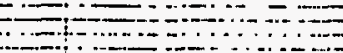
$=$

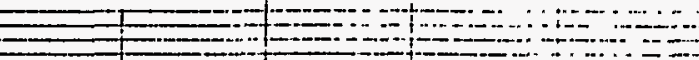

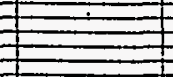

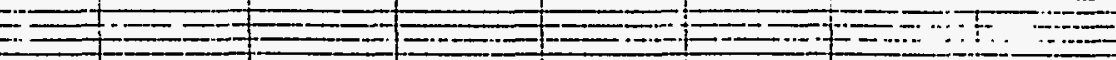
$1=0+100=0$

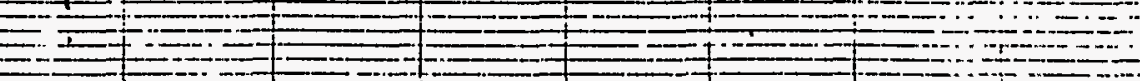
$900200=0$ $0.0=0=0-1=0$ $=$ $0=0-2=0$ 


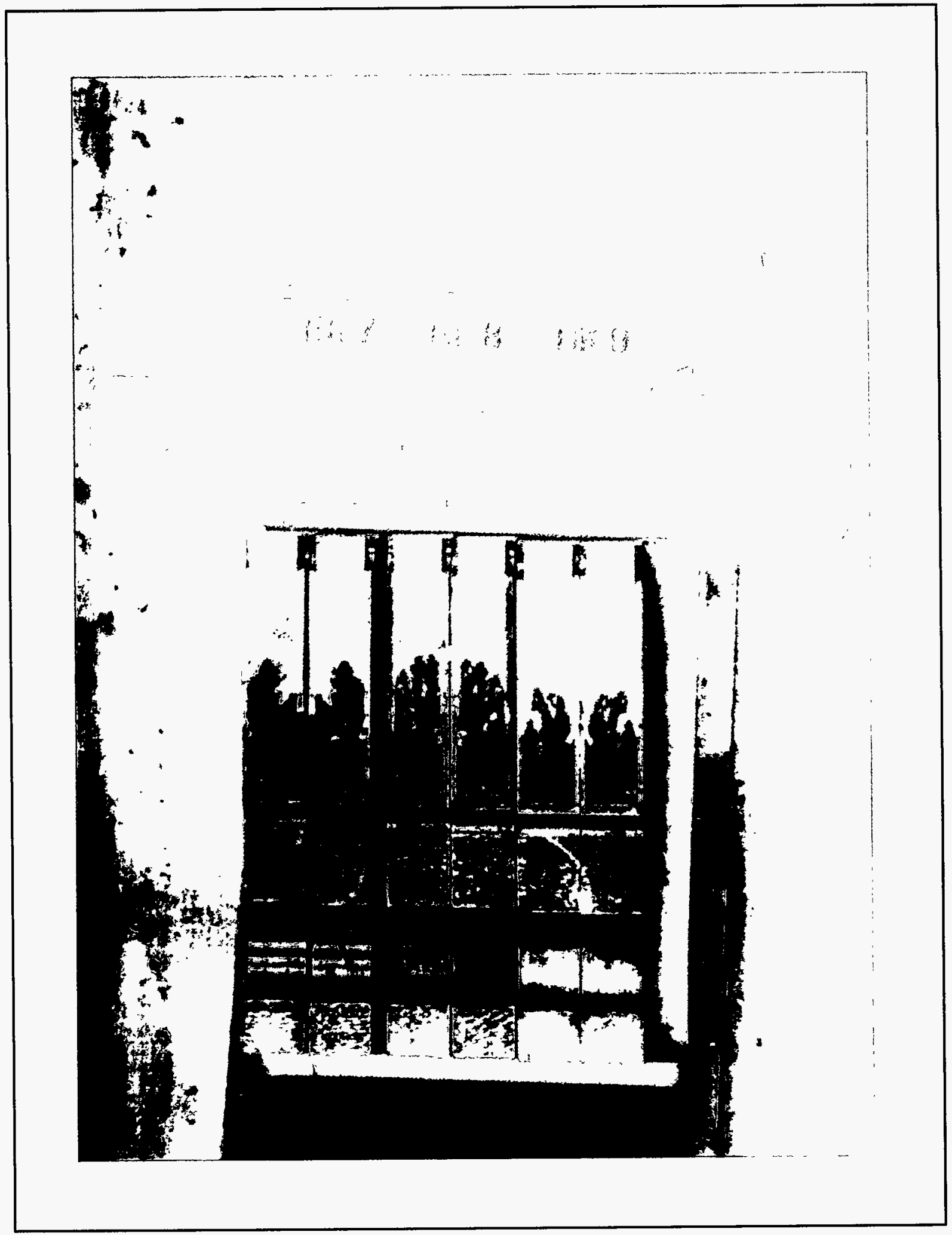

D-5 
วา1เ

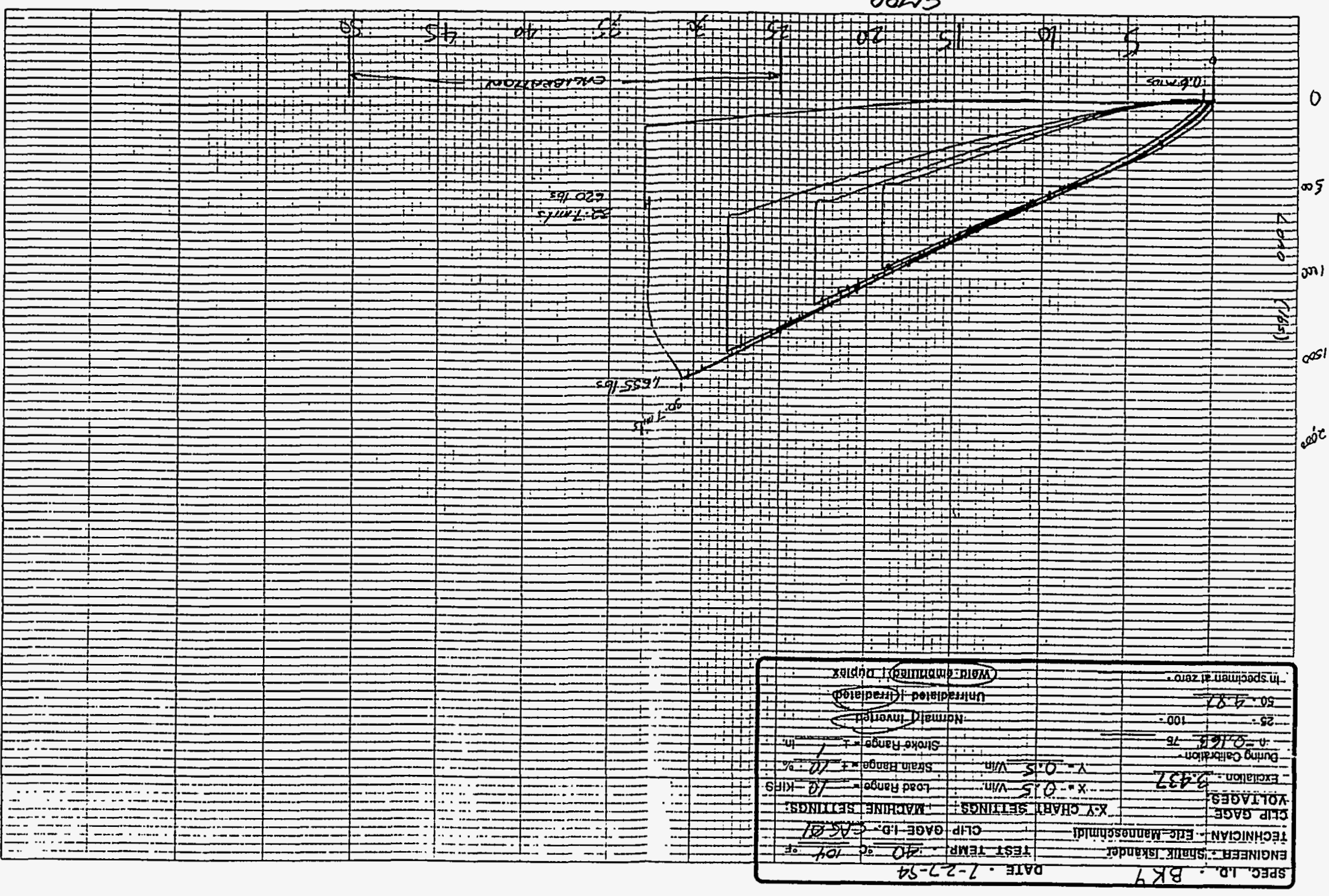




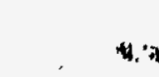

$\therefore$

$\cdots+345$

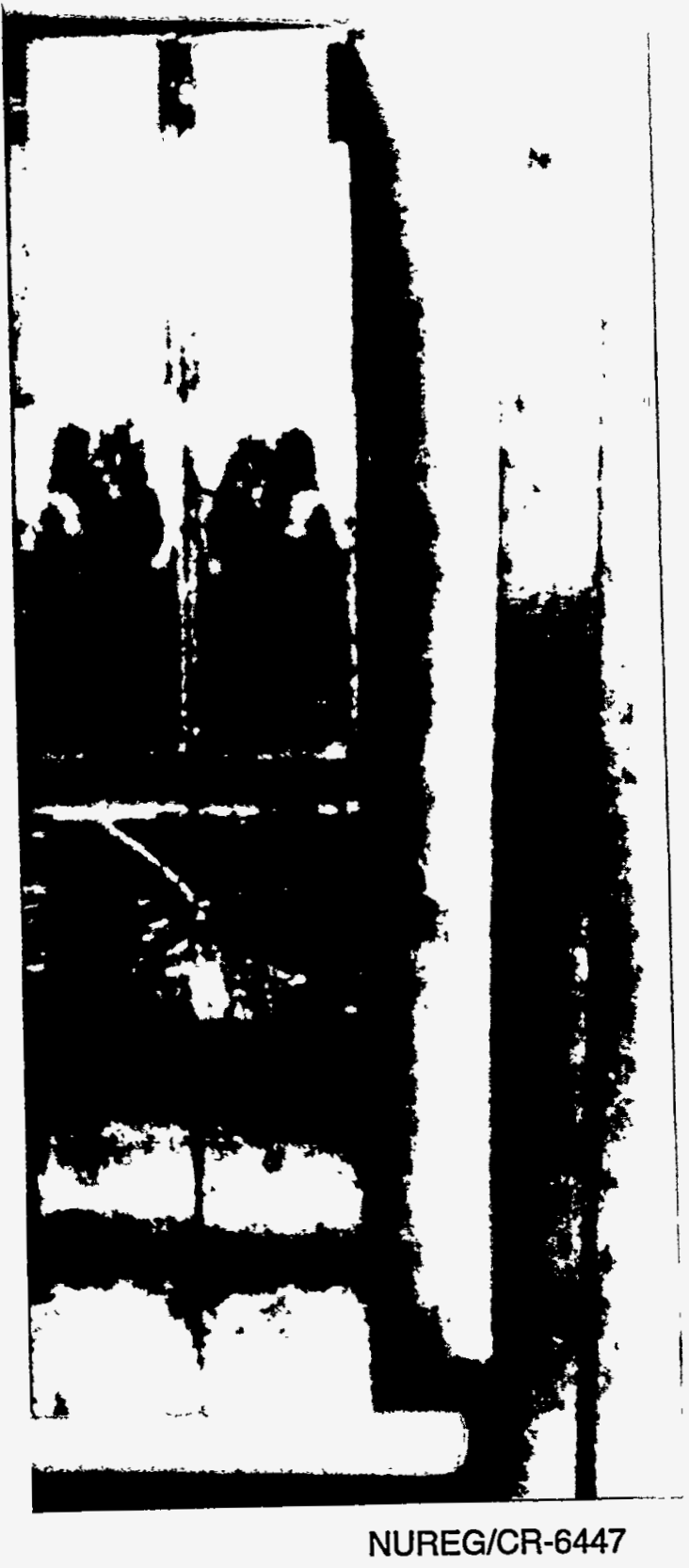




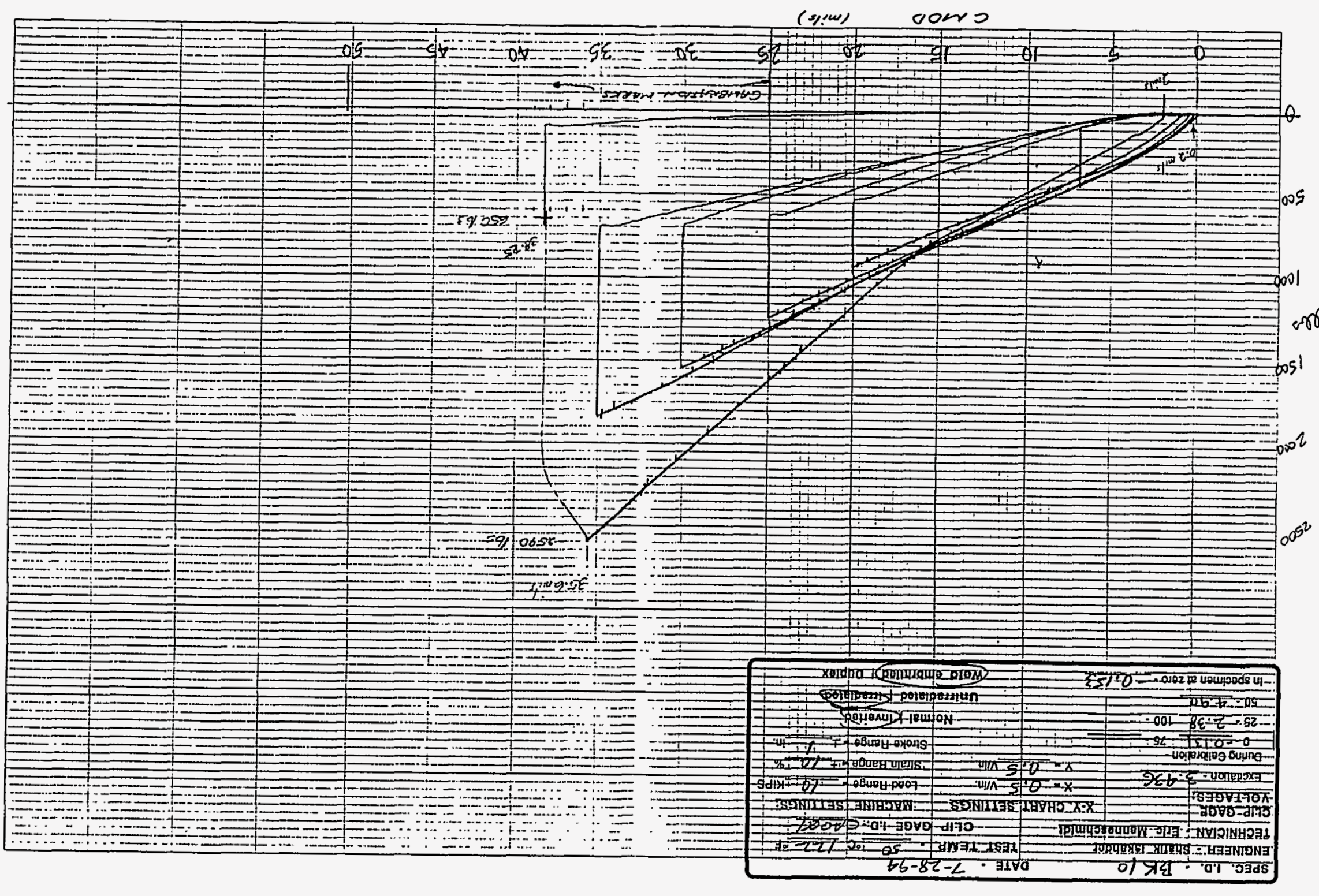




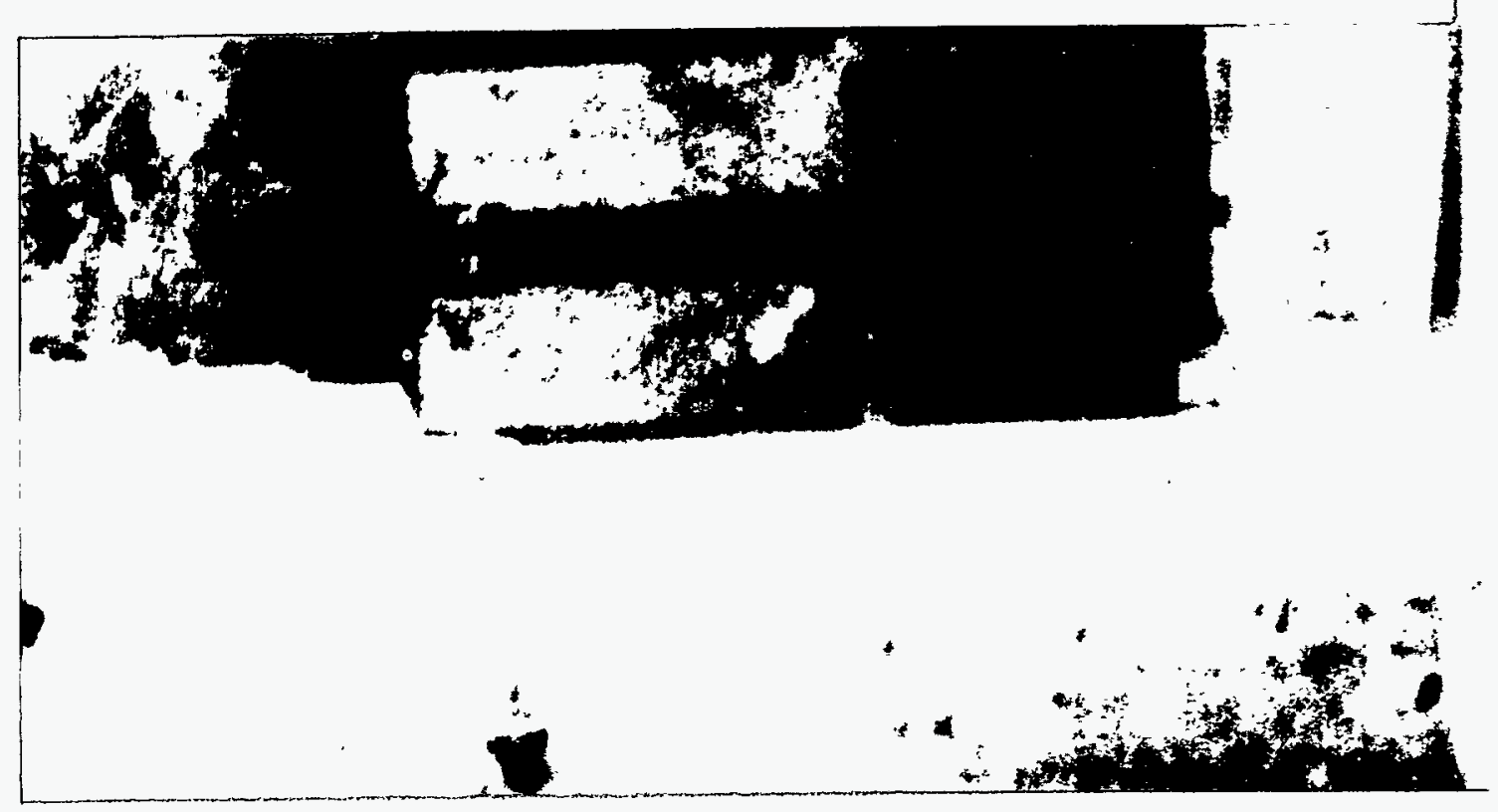




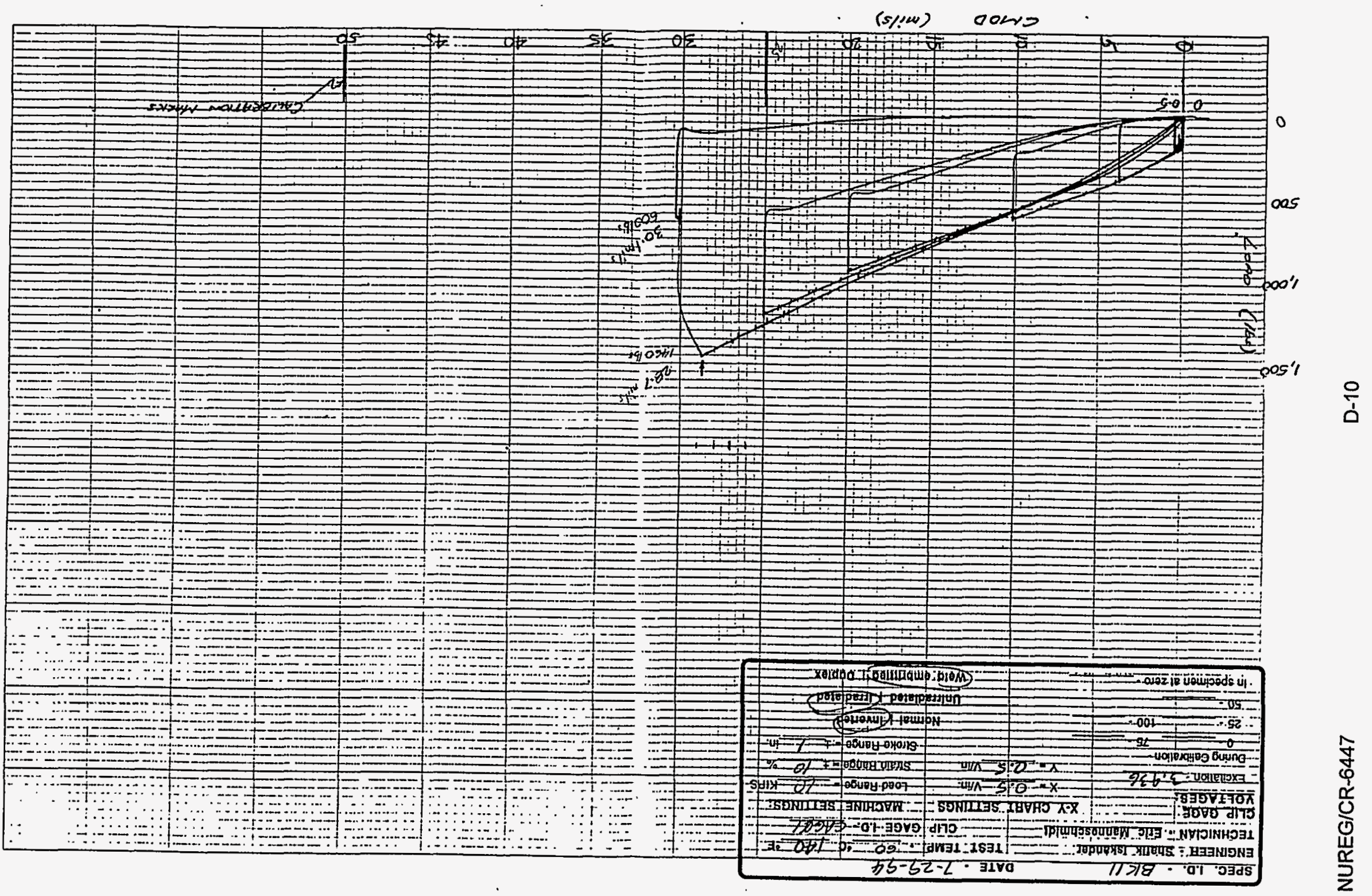




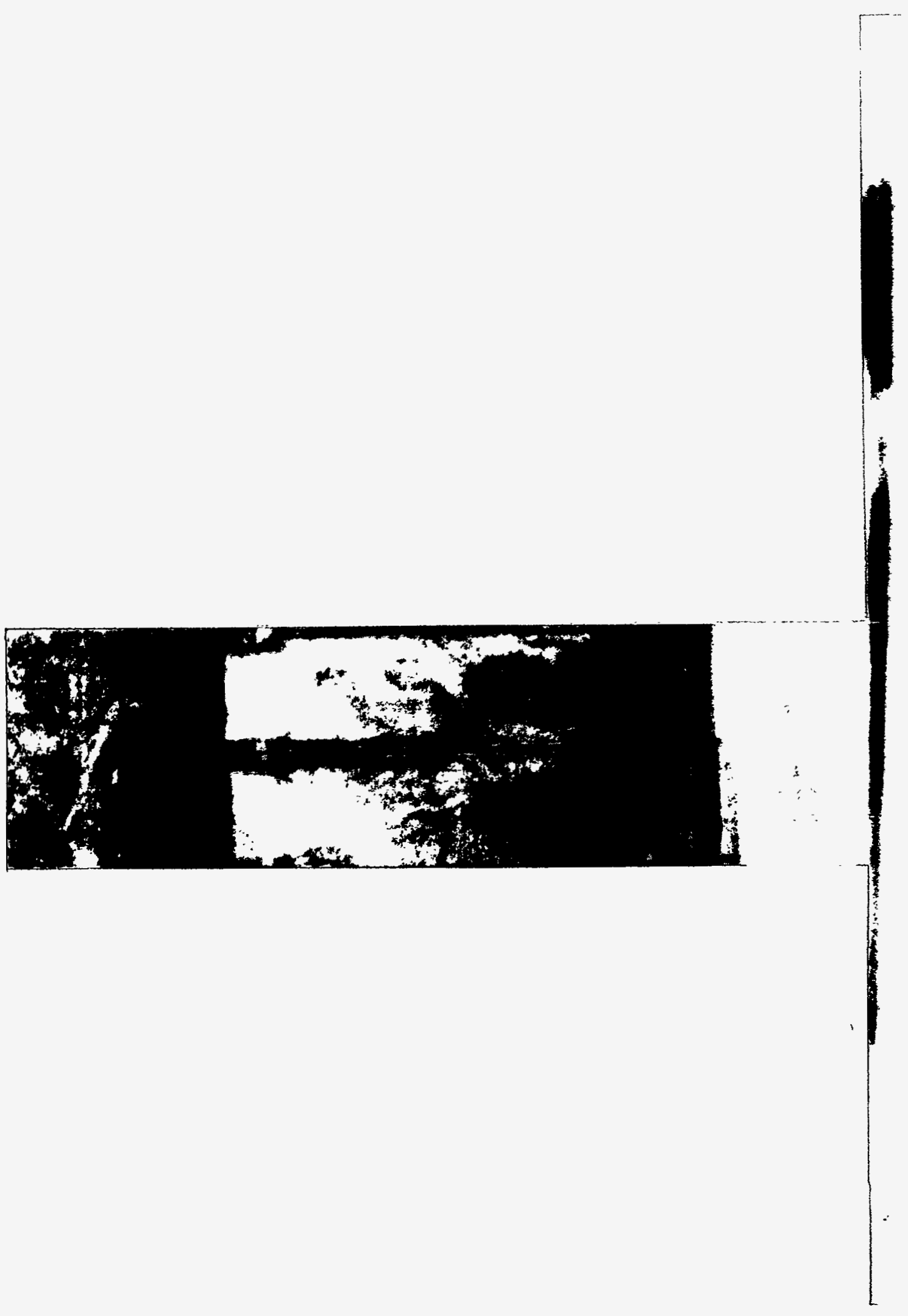




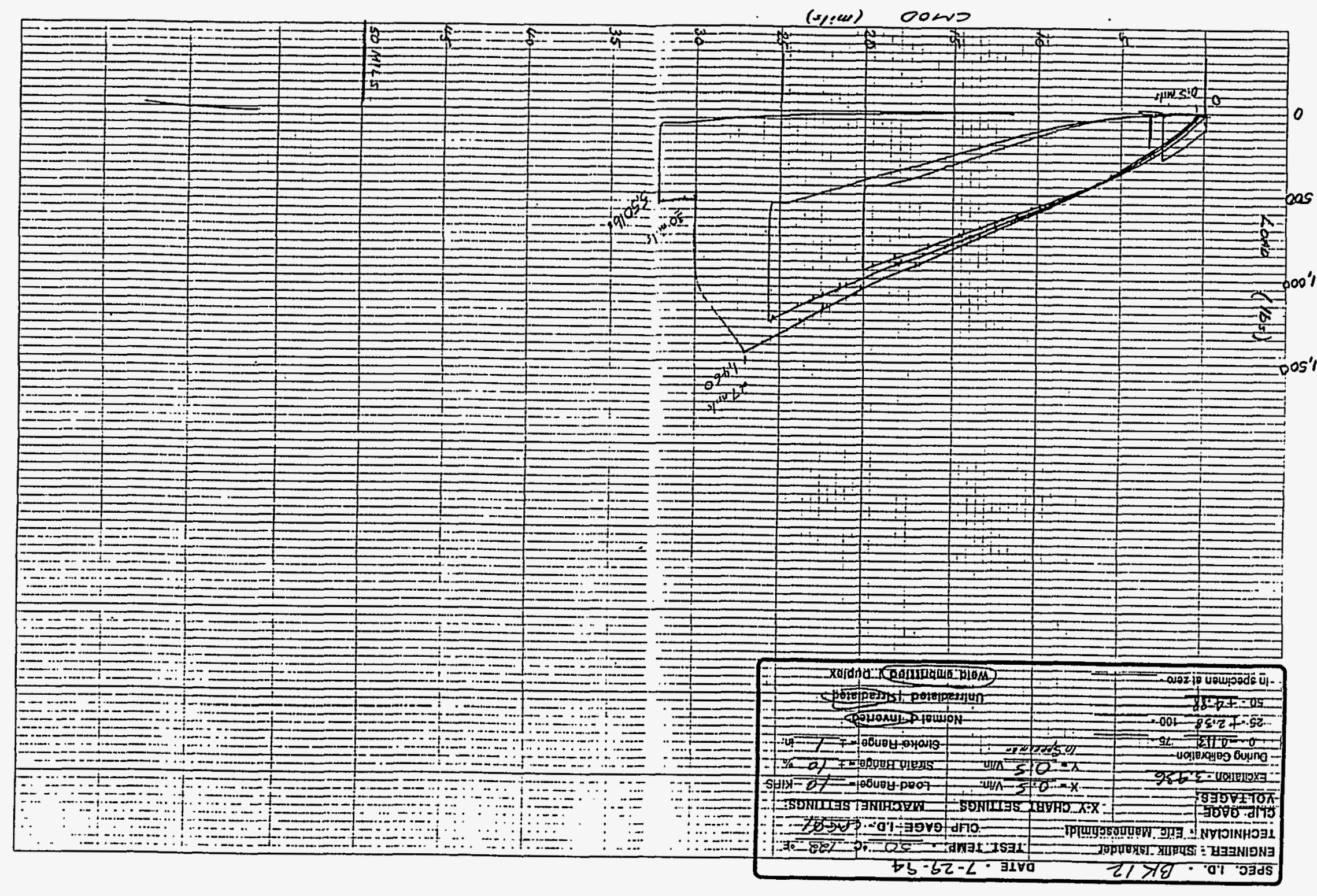




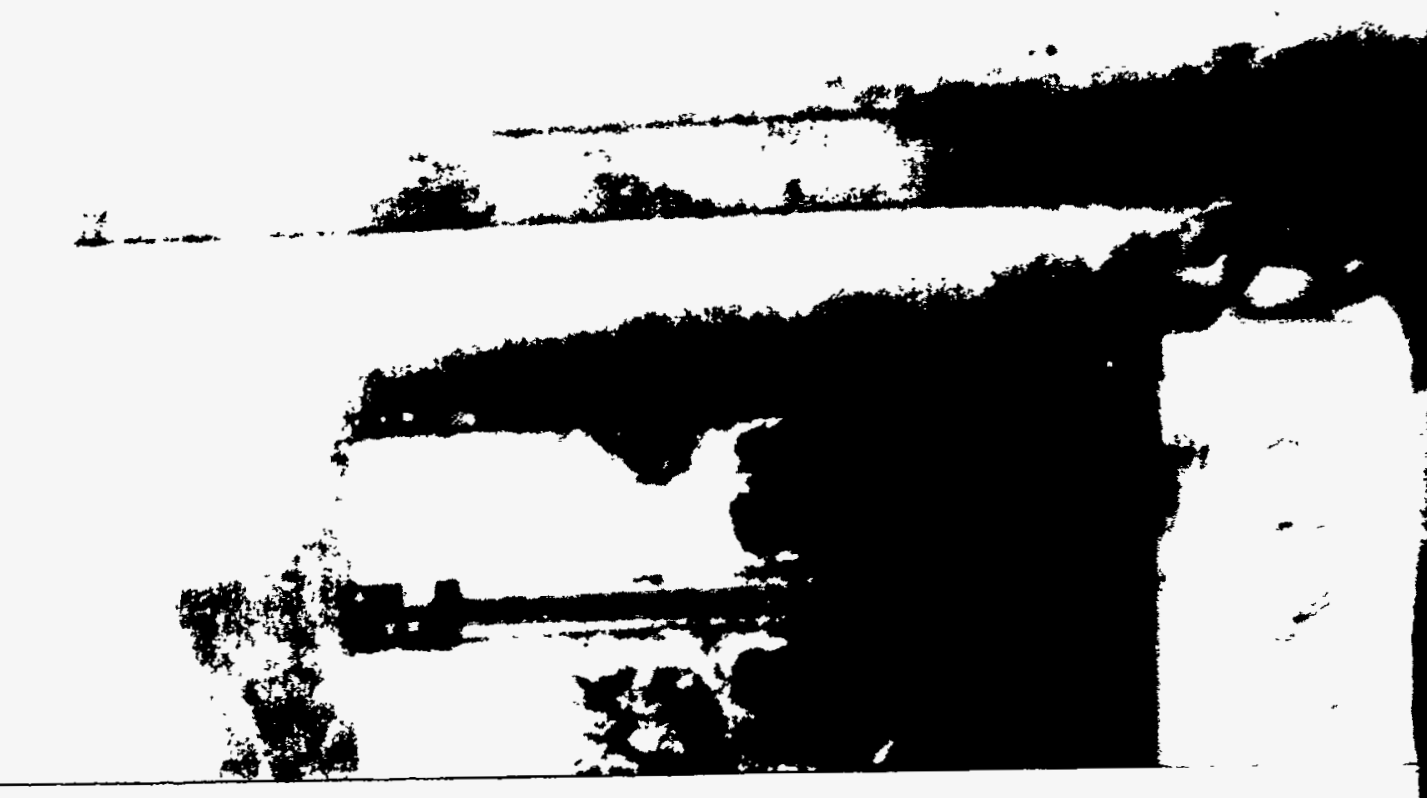




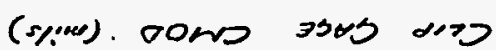

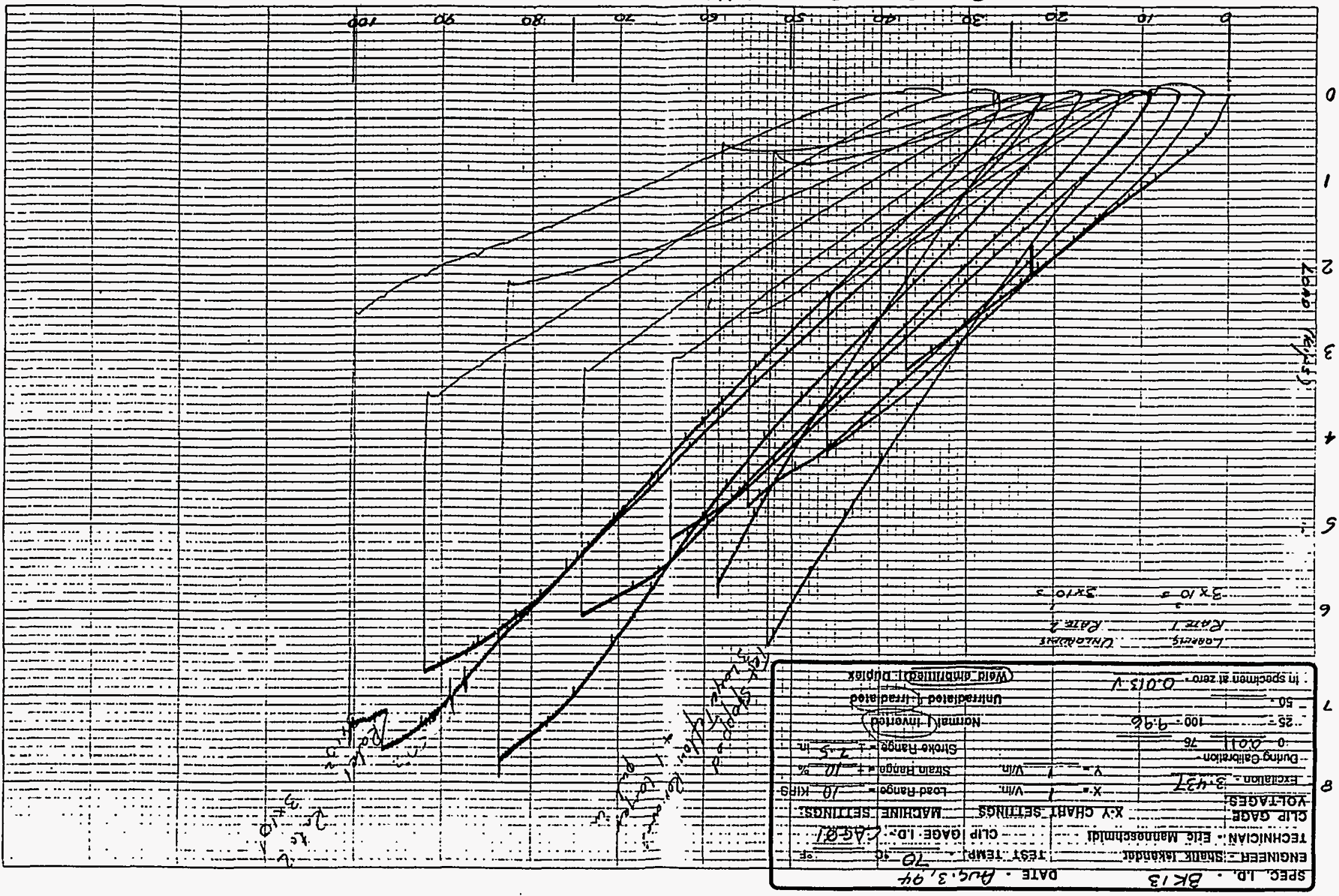




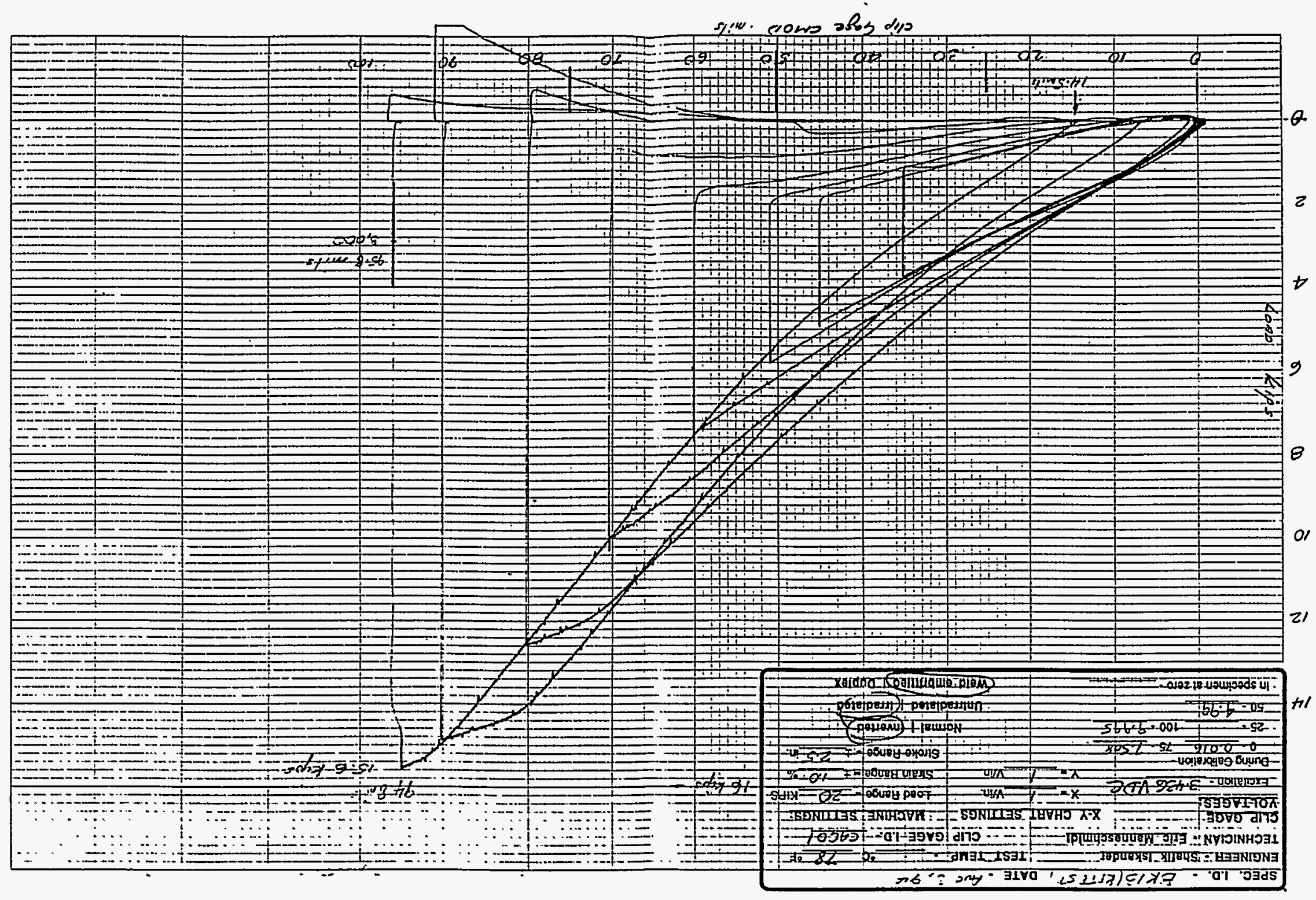

$\frac{20}{5}$ 


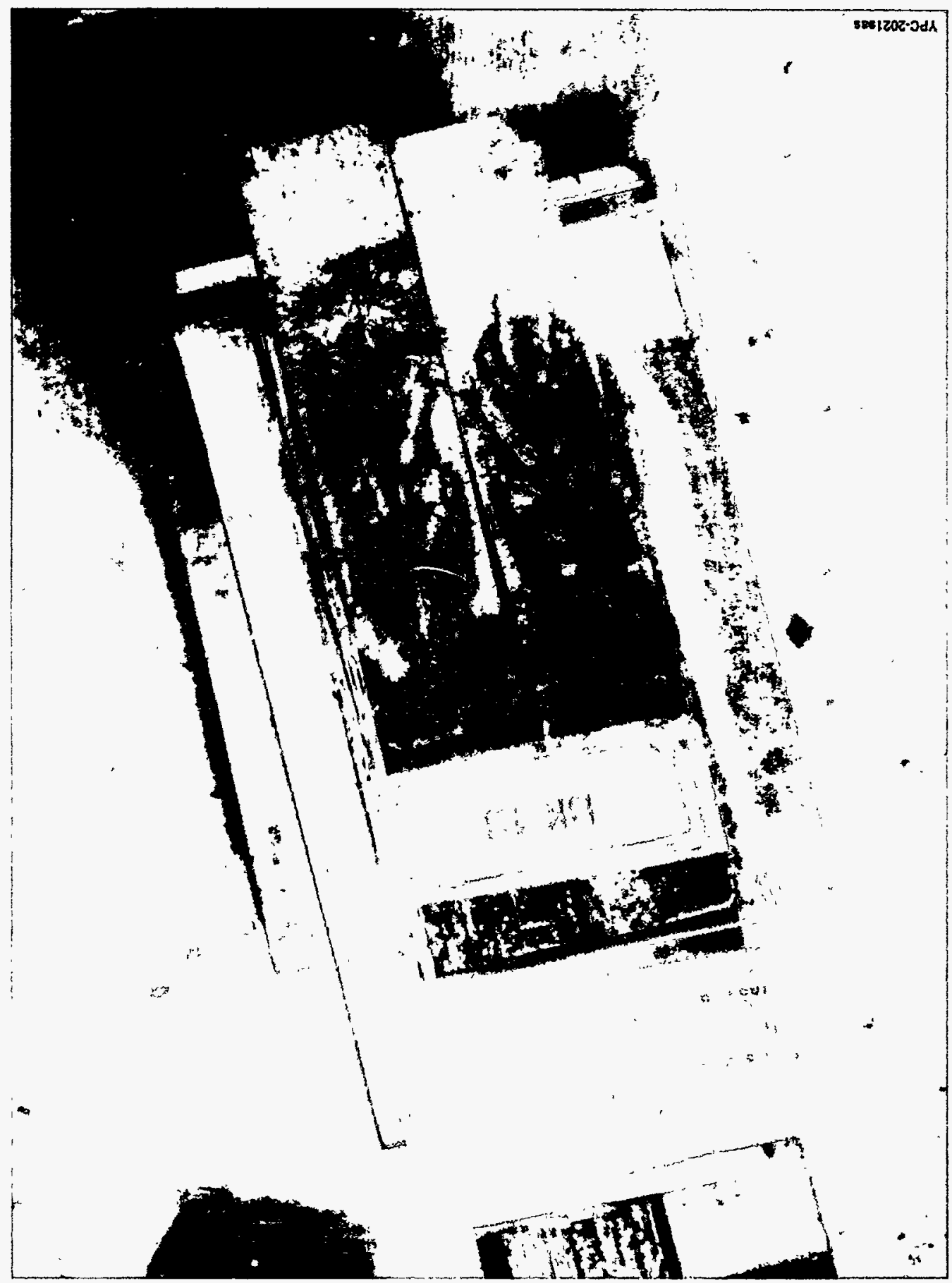




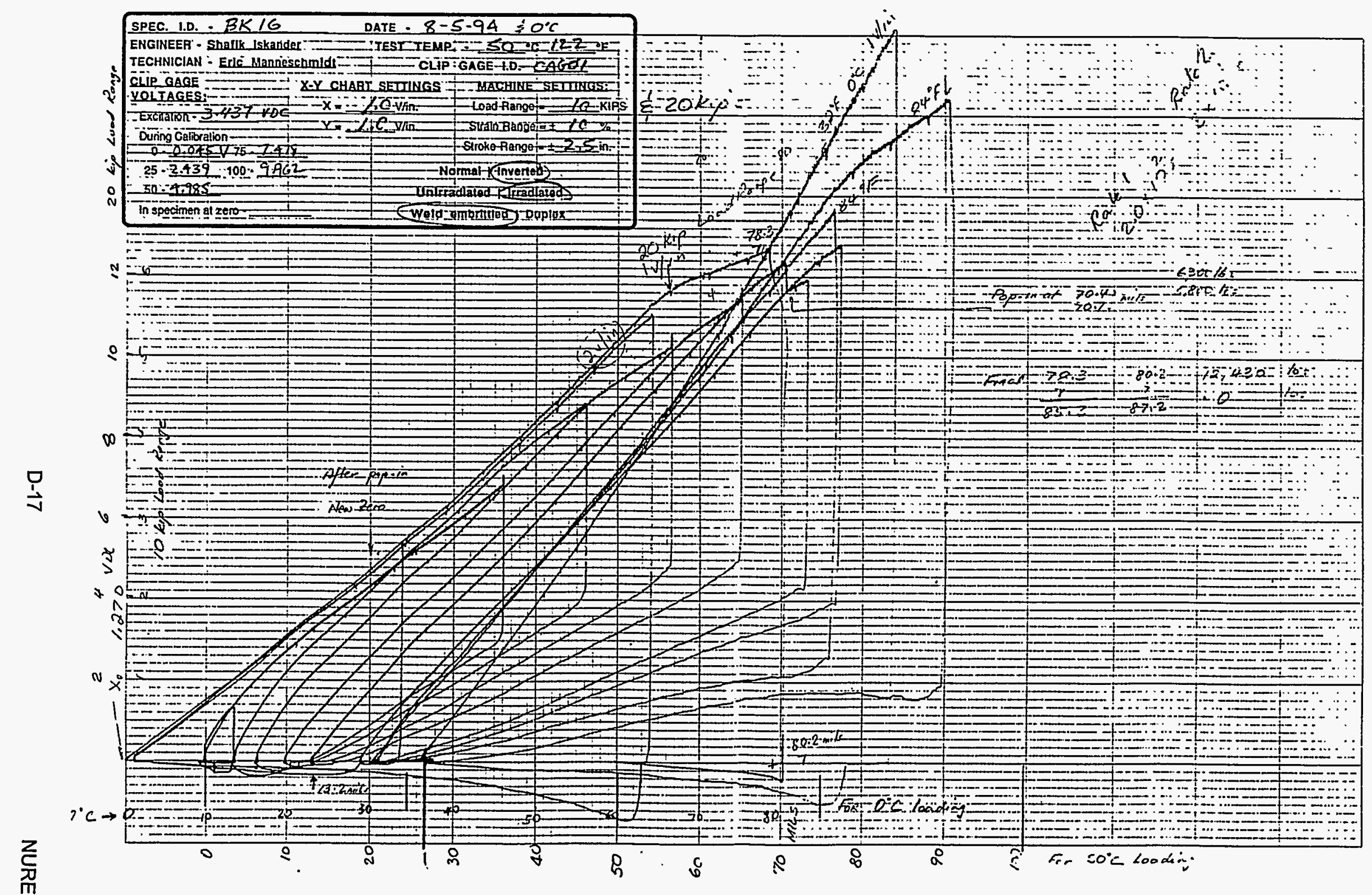




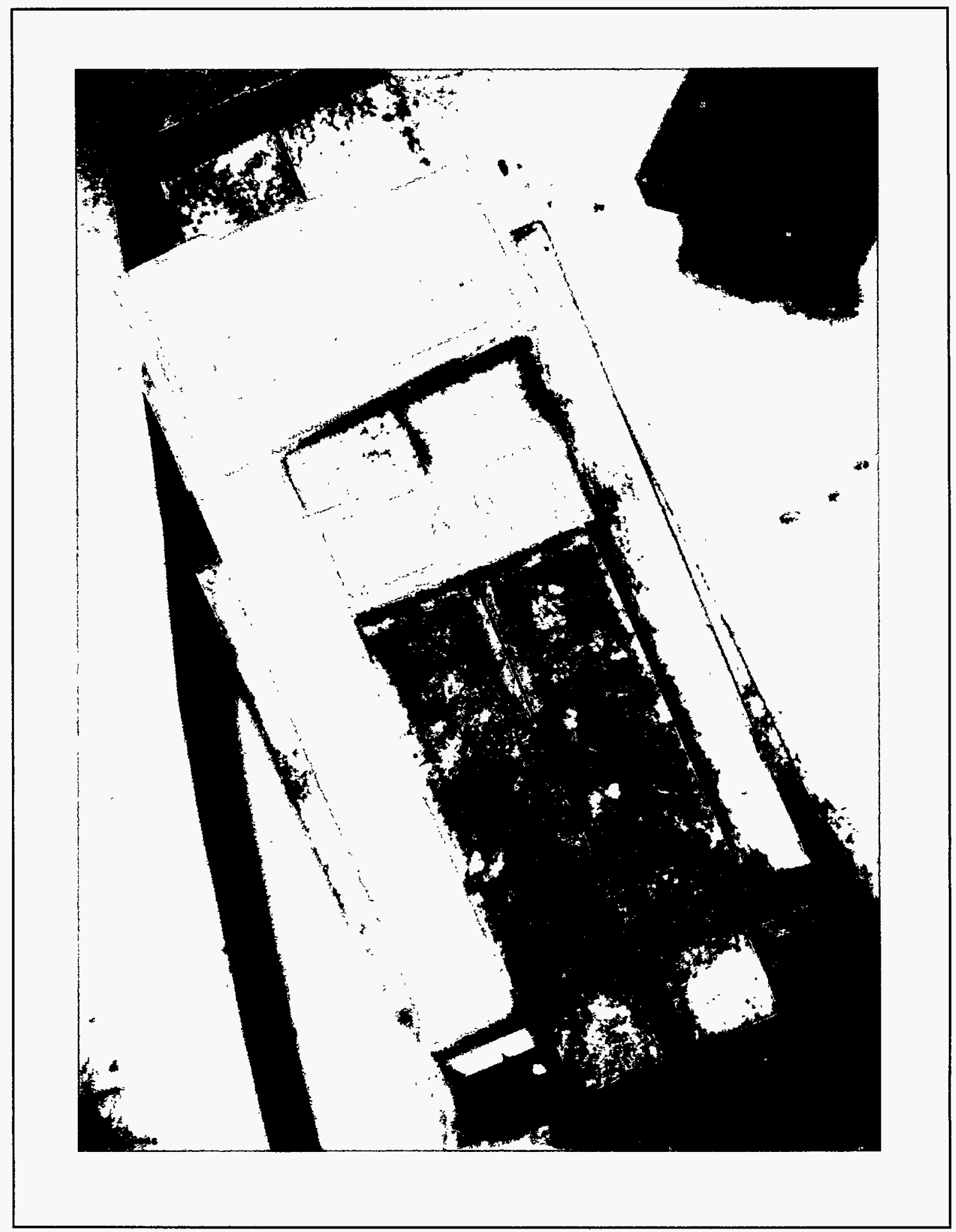

NUREG/CR-6447

D-18 


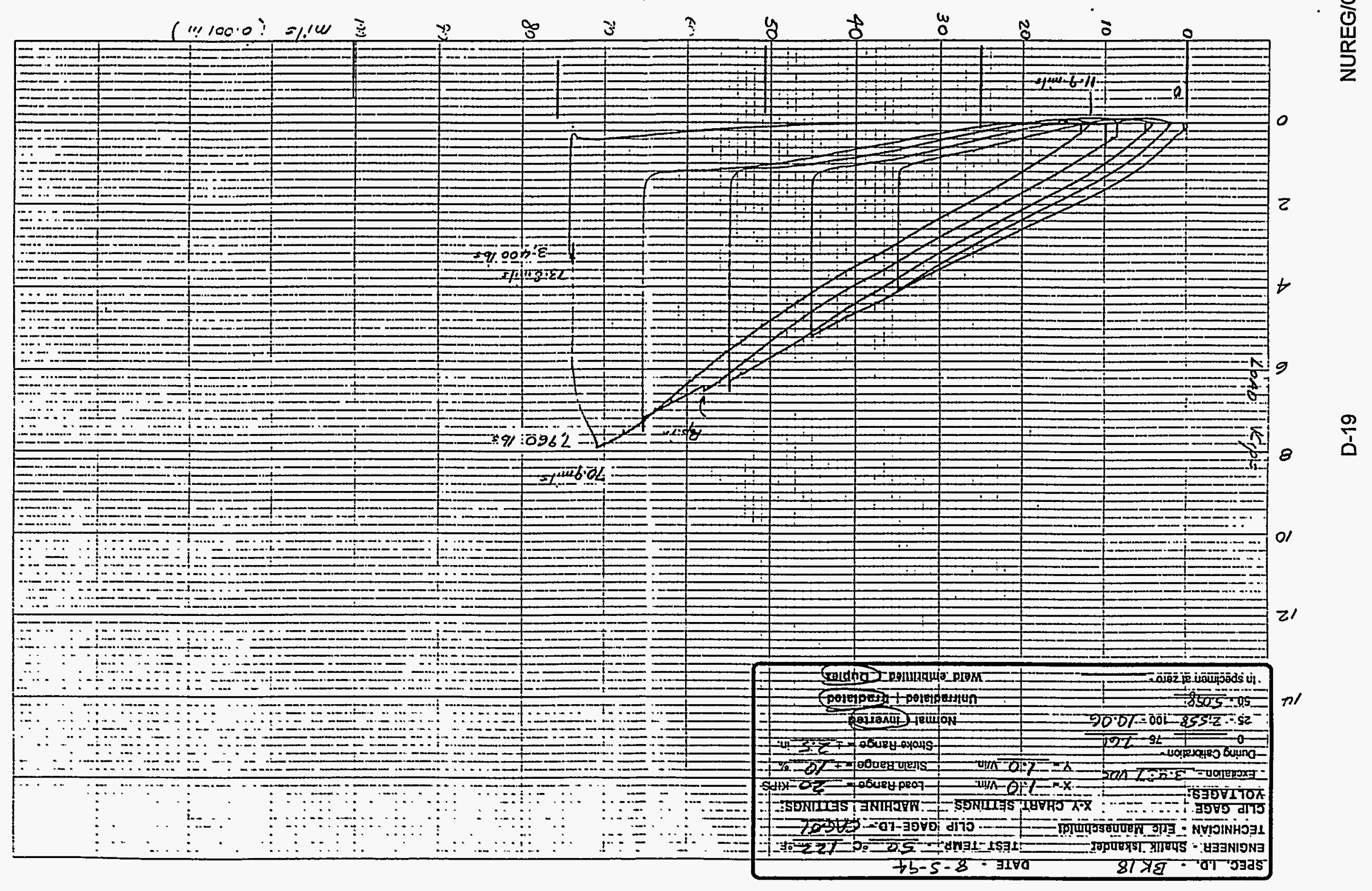




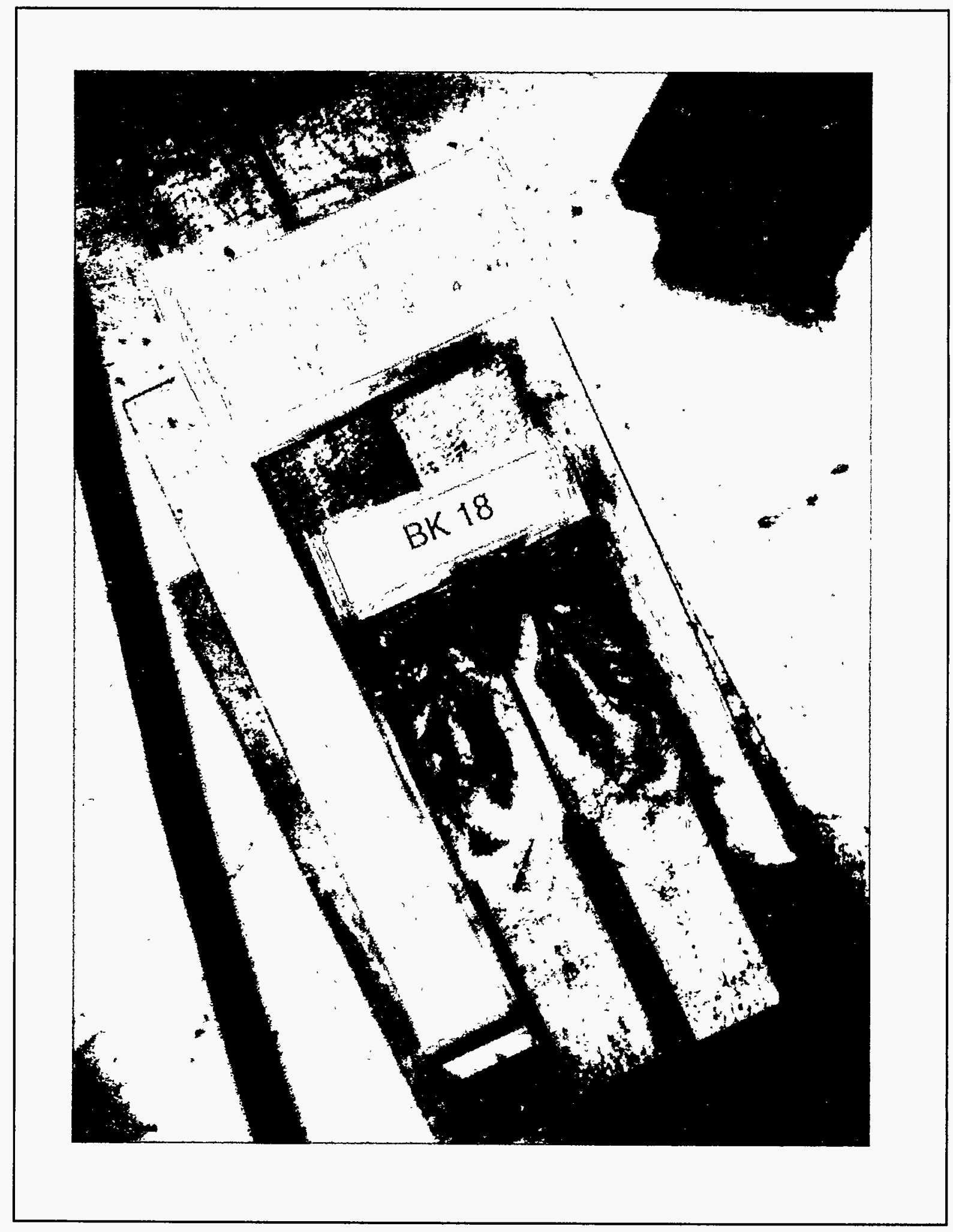




\begin{tabular}{|c|c|}
\hline 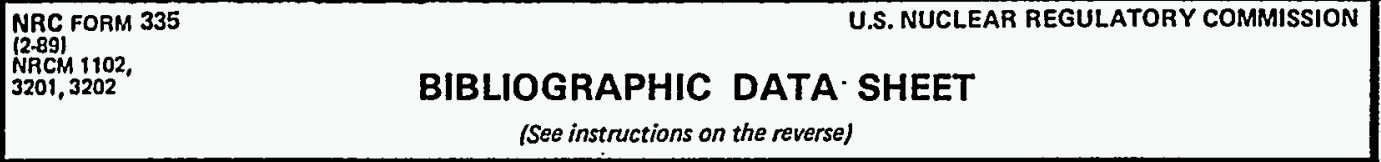 & $\begin{array}{l}\text { 1. REPORT NUMBER } \\
\text { (Aulgonod by NRC. Add Vol., Supp., Rev.. } \\
\text { and Addendum Numbers, if any.) } \\
\text { NUREG/CR-6447 }\end{array}$ \\
\hline 2. TITLE AND SUBTITLE & ORNL-6894 \\
\hline \multirow{3}{*}{ Results of Crack-Arrest Tests on Irradiated A 508 Class 3 Steel } & DATE REPORT PUBLISHED \\
\hline & \begin{tabular}{|c|r|} 
MONTH & YEAR \\
February & 1998 \\
\end{tabular} \\
\hline & $\begin{array}{l}\text { 4. FIN OR GRANT NUMBER } \\
\text { L1098 }\end{array}$ \\
\hline \multirow{2}{*}{ S. K. Iskander, P. P. Milella, and A. Pini } & $\begin{array}{c}\text { 6. TYPE OF REPORT } \\
\text { Technical }\end{array}$ \\
\hline & 7. PERIOD COVERED (Inclusive Dates) \\
\hline
\end{tabular}

name snd maillng oddress)

Oak Ridge National Laboratory

Oak Ridge, TN 37831-6285

9. SPONSORING ORGANIZATION - NAME AND ADDRESS IIf NRC, type "Same as above"; if controctor, provide NRC Division, Office or Region, U.S. Nuclear Regulatory Commission, and mailling address,

Division of Engineering Technology

Office of Nuclear Regulatory Research

U.S. Nuclear Regulatory Commission

Washington, DC 20555-0001

10. SUPPLEMENTARY NOTES

M.G. Vassilaros, NRC Project Manager

11. ABSTRACT (200 words or fess)

Crack-arrest specimens of irradiated A 508 class 3 forging steel were tested and evaluated according to the American Society for Testing and Materials Standard Test Method for Determining Plain-Strain CrackArrest Fracture Toughness, $\mathrm{K}$ Ia, of Ferritic Steels, E 1221-88. The irradiation-induced shifts while small, averaging only about $10 \mathrm{~K}$, are approximately the same as the Charpy $41-\mathrm{J}$ temperature shifts. The specimens were irradiated at temperatures ranging from 243 to $280^{\circ} \mathrm{C}$ to fluences varying from 1.7 to $2.7 \times$ $10^{19}$ neutrons $/ \mathrm{cm}^{2}(>1 \mathrm{MeV})$. 